\title{
Pedestrian Survey and NRHP Eligibility Testing of Sites within a Proposed Detention Facility in Webb County, Texas
}

Karla J. Córdova

Antonia L. Figueroa

Center for Archeological Research, University of Texas at San Antonio

Russell D. Greaves

Bruce K. Moses

Steve A. Tomka

Raba Kistner

Follow this and additional works at: https://scholarworks.sfasu.edu/ita

Part of the American Material Culture Commons, Archaeological Anthropology Commons, Environmental Studies Commons, Other American Studies Commons, Other Arts and Humanities Commons, Other History of Art, Architecture, and Archaeology Commons, and the United States History Commons

Tell us how this article helped you.

This Article is brought to you for free and open access by the Center for Regional Heritage Research at SFA ScholarWorks. It has been accepted for inclusion in Index of Texas Archaeology: Open Access Gray Literature from the Lone Star State by an authorized editor of SFA ScholarWorks. For more information, please contact cdsscholarworks@sfasu.edu. 


\section{Pedestrian Survey and NRHP Eligibility Testing of Sites within a Proposed Detention Facility in Webb County, Texas}

\section{Creative Commons License}

\section{(c) (1) \&}

This work is licensed under a Creative Commons Attribution-NonCommercial 4.0 International License 


\section{Pedestrian Survey and NRHP Eligibility Testing of Sites within a Proposed Detention Facility in Webb County, Texas}

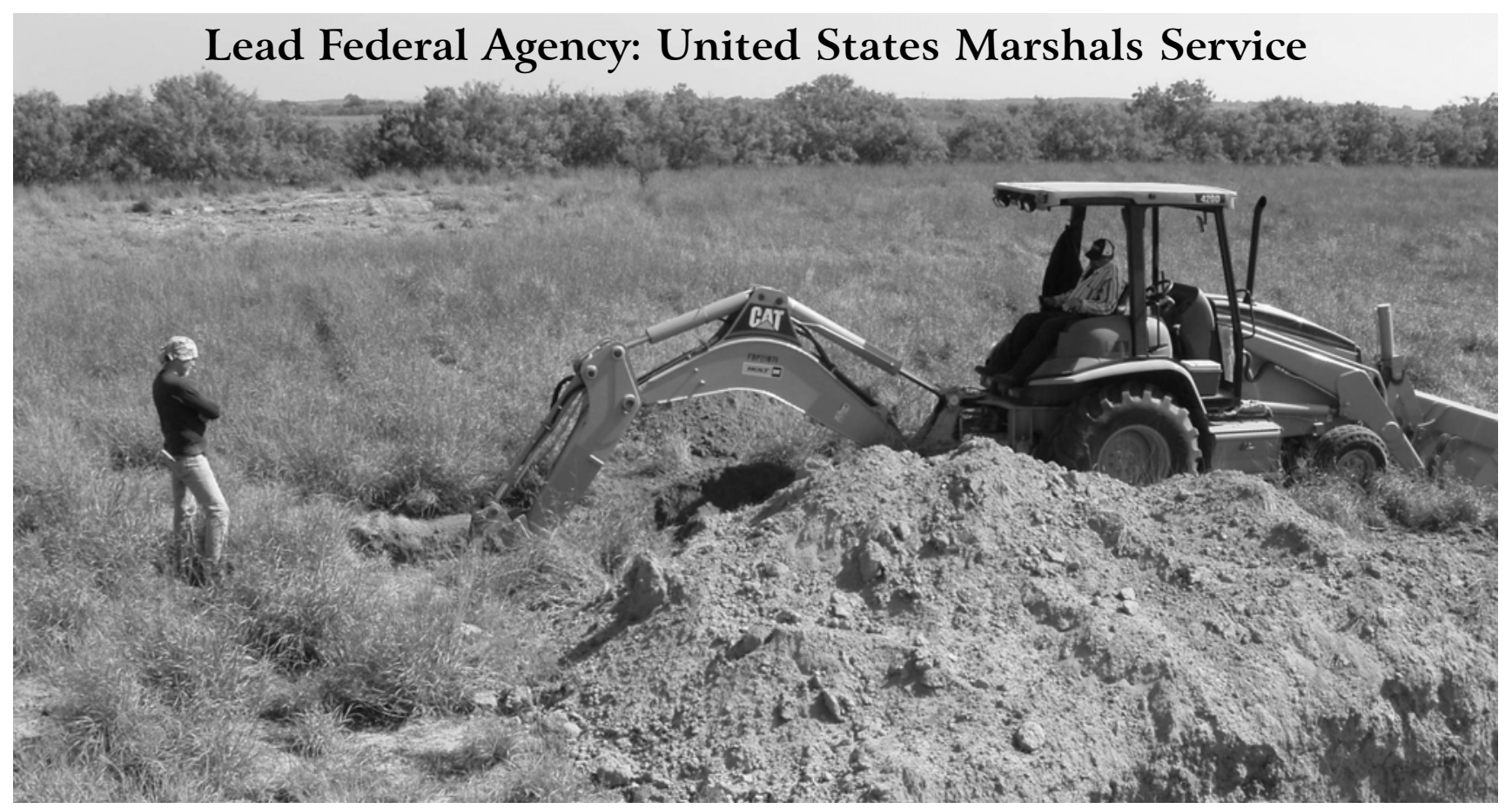

by

Karla J. Córdova, Antonia L. Figueroa, Russell D. Greaves, Bruce K. Moses, and Steve A. Tomka

with a Contribution by

Raymond P. Mauldin

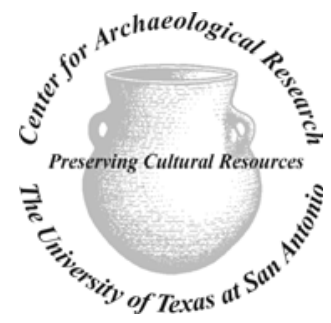

Archaeological Report, No. 359

Center for Archaeological Research, The University of Texas at San Antonio (C) 2005 


\title{
Pedestrian Survey and National Register of Historic Places Eligibility Testing of Sites within a Proposed Detention Facility in Webb County, Texas
}

\author{
Lead Federal Agency: \\ United States Marshals Service
}

\author{
by \\ Karla J. Córdova, Antonia L. Figueroa, Russell D. Greaves, \\ Bruce K. Moses, and Steve A. Tomka \\ with a Contribution by \\ Raymond P. Mauldin
}

Raymond P. Mauldin

Principal Investigator

Submitted to:

MACTEC Engineering \& Consulting, Inc.

2100 Riverchase Center, Suite 450

Birmingham, Alabama 35244

Prepared for:

The GEO Group, Inc.

One Park Place, Suite 700

621 Northwest $53^{\text {rd }}$ Street

Boca Raton, Florida 33487

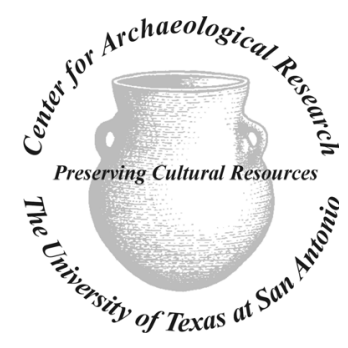

Prepared by:

Center for Archaeological Research The University of Texas at San Antonio Archaeological Report, No. 359 Ccopyright 2005 
A list of publications offered by the Center for Archaeological Research is available. Call (210) 458-4378; write to the Center for Archaeological Research, The University of Texas at San Antonio, 6900 N. Loop 1604 W., San Antonio, Texas 78249-0658; e-mail to car@lonestar.utsa.edu; or visit CAR's web site at http://car.utsa.edu. 


\section{Abstract:}

The Center for Archaeological Research (CAR) of The University of Texas at San Antonio was contracted by MACTEC Engineering \& Consulting, Inc. (hereafter, MACTEC) to perform Phase I archaeological survey and Phase II testing prior to the construction of a detention facility in Webb County, Texas. Section 106 of the National Historic Preservation Act (NHPA) requires federal agencies to take into consideration the effects of proposed undertakings on cultural resources within the Area of Potential Effect (APE). While the proposed undertaking is being developed by The GEO Group, Inc. on privately owned property and is funded by private resources, the anticipated use of the facility by the United States Marshals Service makes this project a federal undertaking as defined under 36 CFR part 800.16(y). As such, the project must comply with Section 106 of the NHPA. The Texas Historical Commission (THC) is the reviewing agency for the project.

In December, 2004, CAR conducted an intensive survey of the APE for the proposed construction of the detention facility. The survey followed MACTEC's preliminary cultural resources assessment and included pedestrian survey with shovel testing within an approximate 160-acre tract, and backhoe trenching of selected locations within the approximate 30-acre APE of the proposed undertaking. Eleven field sites were defined as a result of the intensive survey (Field Site 1 [41WB634], Field Site 2, Field Site 3 [41WB636], and Field Sites 4-11). Subsequently, Phase II investigations were conducted by CAR to evaluate National Register of Historic Places (NRHP) eligibility and State Archeological Landmark (SAL) designation for eight of the originally identified field sites (numbers 2 and 5-11). The Phase II investigations included the hand excavation of test units as well as mechanical auger testing.

Based on the combined results of the Phase I survey and Phase II investigations, seven sites were reported to the Texas Archeological Research Laboratory and assigned trinomials (41WB634 through 41WB640). Site 41WB639 was identified as containing archaeological components with significant research potential and therefore is recommended eligible for nomination to the NRHP and for formal designation as a SAL. The site contains a Middle Archaic component buried between $100 \mathrm{~cm}$ and $130 \mathrm{~cm}$ below surface that may yield information on a regional level. Based on the findings within the proposed project area, the site is interpreted as eligible for listing in the NRHP under Criterion D. Likewise, the site is interpreted as having the potential to contribute to a better understanding of the prehistory of Texas, and therefore eligible for SAL designation based on Criterion 1. Given the depth of the component and the shallow nature of the anticipated disturbances in the vicinity of the site (two feet or about $60 \mathrm{~cm}$ below surface), no construction impact is likely to effect the buried component and no further work is recommended at the site. However, in the case that construction parameters are changed and anticipated impacts reach below two feet (60 $\mathrm{cm}$ ) in depth, data recovery efforts are recommended at the site.

In addition, site 41WB634 was identified during the survey as having some research potential, although the NRHP and SAL eligibility of the site has not been determined. According to present construction plans, the site falls outside of the facilities footprint and will not be disturbed by construction activities. No additional archaeological investigations are recommended at the present time. The site contains a temporally unassigned, shallowly buried $(10-50 \mathrm{~cm}$ below surface) archaeological component. If at a future date the facilities footprint is relocated or hitherto unanticipated subsurface disturbances are planned in the vicinity of this site, Phase II testing is recommended to establish the NRHP eligibility of the site.

Finally, archaeological components buried at a depth of $70 \mathrm{~cm}$ below surface or deeper have been identified at sites 41WB637, 41WB638, and 41WB639. The NRHP/SAL eligibility of these deposits has not been fully assessed. However, the impacts of activities above these sites will consist of the planting of a grass cover and will otherwise be limited to 
foot traffic and therefore will be consistent with the guidelines set in the Intentional Burial of Sites as defined by the Texas Historical Commission. Therefore, no adverse affects will come to the deeply buried deposits at sites 41WB637, 41WB638 and 41WB639.

The cultural materials recovered during these investigations were processed at the CAR laboratory. Following analysis, several artifact classes possessing little scientific values were discarded in consultation with MACTEC and the landowner. These artifact classes included snail shells, unburned rocks, heat spalls, modern glass, plastic, and unidentified metal fragments. In all instances, discarded materials were documented and their counts included in the report and curation documentation. All data was entered into Access and Excel spreadsheets, and copies of electronic and paper records were submitted to the client. All artifacts, including human remains, were returned to the landowner and all copies of project records are permanently curated at the Center for Archaeological Research. 


\section{Table of Contents:}

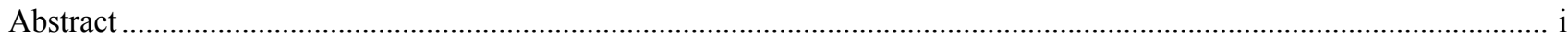

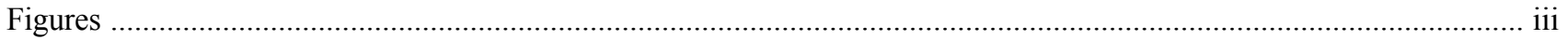

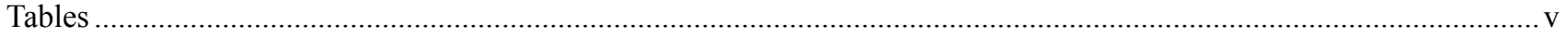

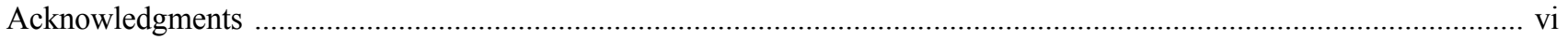

Chapter 1: Introduction

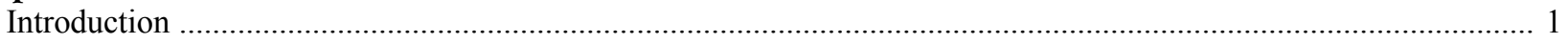

Chapter 2: Background and Previous Investigations

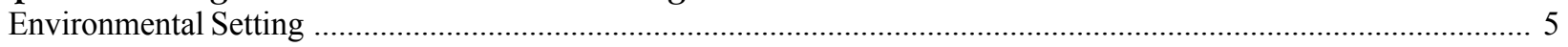

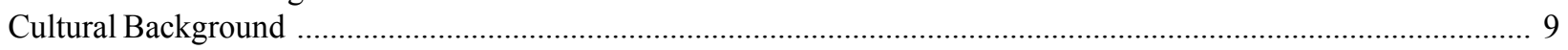

Chapter 3: Phase I Intensive Pedestrian Survey and Geoarchaeological Investigations

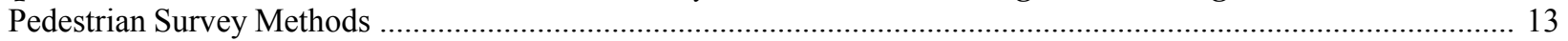

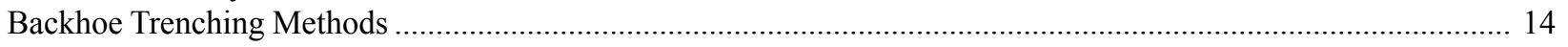

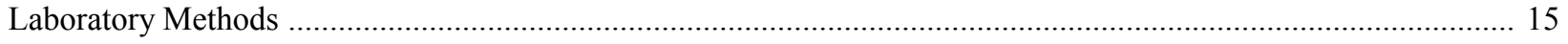

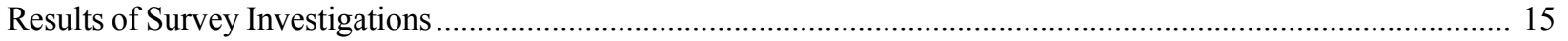

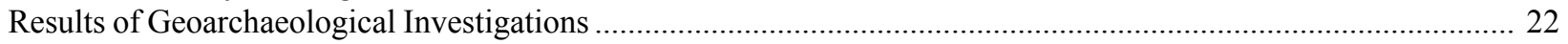

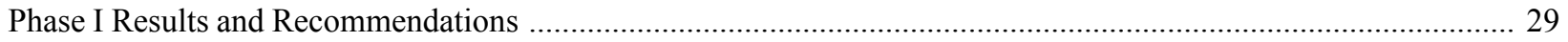

Chapter 4: Phase II National Register of Historic Places Eligibility and State Archeological Landmark Designation Testing

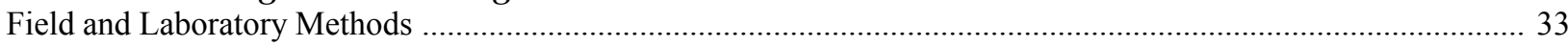

Chapter 5: Phase II Testing Results and Recommendations

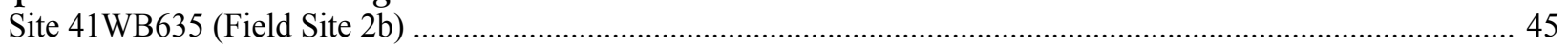

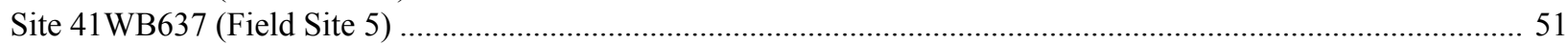

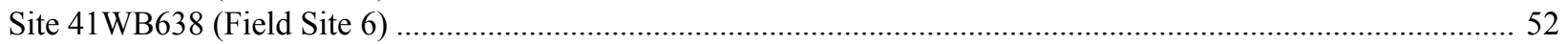

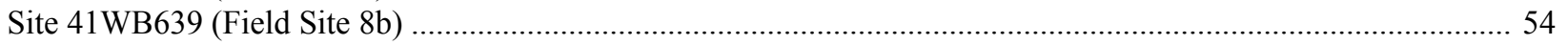

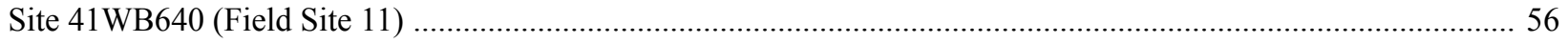

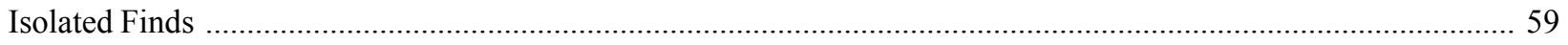

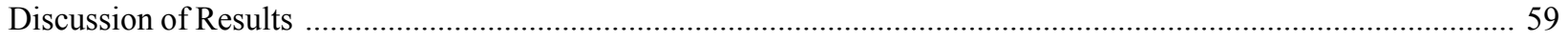

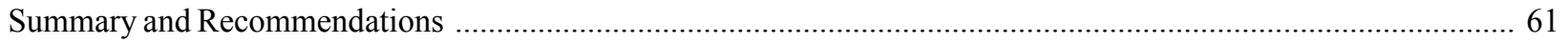

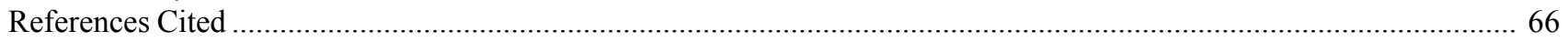

Appendix A: Prehistoric Artifacts Recovered during MACTEC Previous Investigation

Prehistoric Artifacts Recovered during MACTEC Previous Investigation ................................................................ 70

Appendix B: Historic Artifacts Recovered during MACTEC Previous Investigation

Historic Artifacts Recovered during MACTEC Previous Investigation ................................................................... 72

Appendix C: Profile Descriptions for Backhoe Trenches

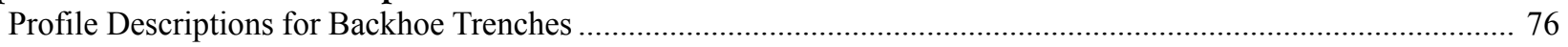

Appendix D: Magnetic susceptibility Testing

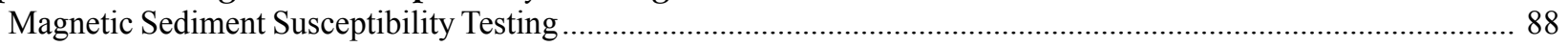

Appendix E: Letter from The GEO Group, Inc. with Description of the Nature of Impacts

Letter from The GEO Group, Inc. with Description of the Nature of Impacts within the Facility Footprint .............. 94 


\section{Figures:}

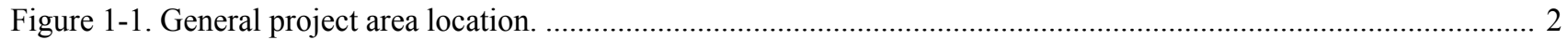

Figure 1-2. Project area with proposed impacts shown. ................................................................................... 3

Figure 2-1. Brush piles distributed throughout the project area. ........................................................................... 5

Figure 2-2. Operating well in the northwestern portion of the project area.................................................................. 6

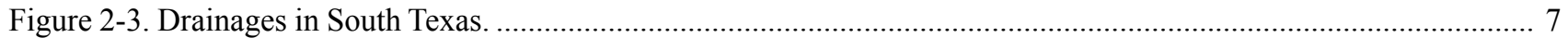

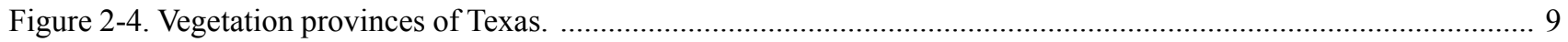

Figure 2-5. Map showing locations of geologic sources of obsidian from the Huasteca Region Complex sites. ................ 11

Figure 2-6. Provisional archaeological sites identified by MACTEC ………................................................. not published

Figure 3-1. Backhoe trenching activities, Backhoe Trench 6-4 at Field Site 6. .......................................................... 14

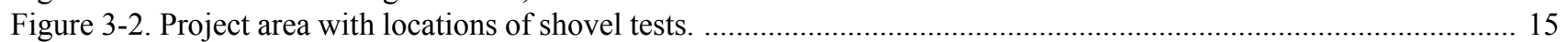

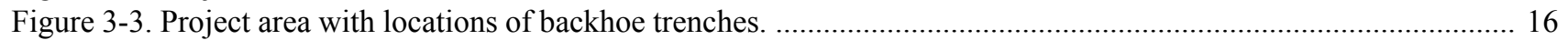

Figure 3-4. Map of Field Site 1 showing locations of shovel tests. ....................................................................... 17

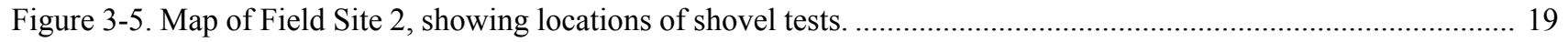

Figure 3-6. Map of Field Site 3 showing locations of shovel tests. ......................................................................... 21

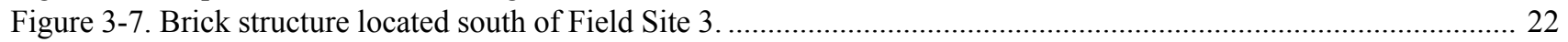

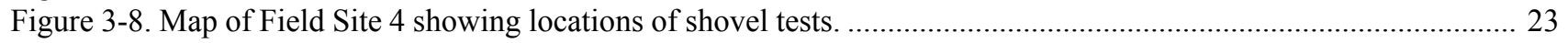

Figure 3-9. South wall profile of Backhoe Trench 17. ............................................................................................ 25

Figure 3-10. North wall profile of Backhoe Trench 10, Field Site 7 ........................................................................ 26

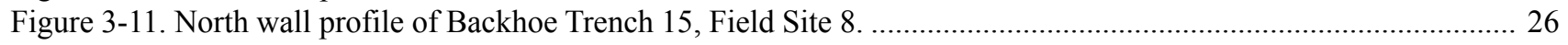

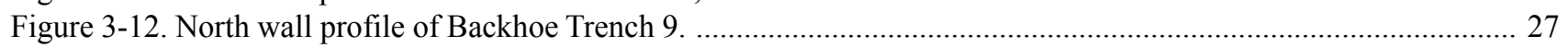

Figure 3-13. North wall profile of Backhoe Trench 14. ............................................................................................... 27

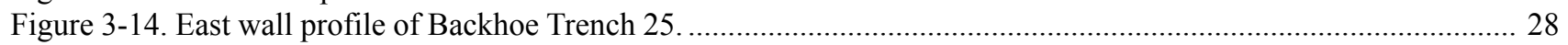

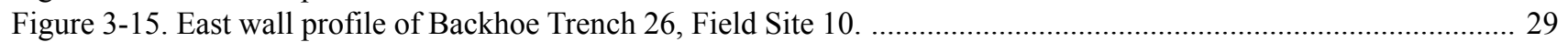

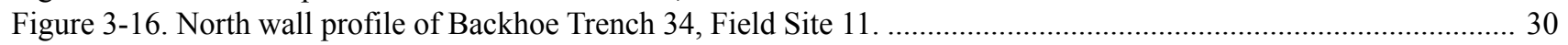

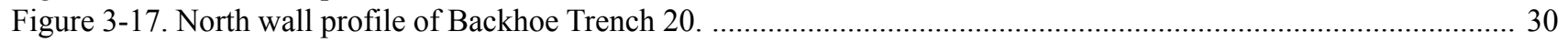

Figure 3-18. Locations of field sites (FS) as defined by the Phase I survey efforts. ....................................... not published

Figure 4-1. Map of Field Site 2 showing locations of hand-excavated units and shovel tests. ...................................... 34

Figure 4-2. Map of Field Site 6 showing locations of hand-excavated units and backhoe trenches. ............................... 36

Figure 4-3. Map of Field Site 5 showing locations of auger bores, the backhoe trench, and

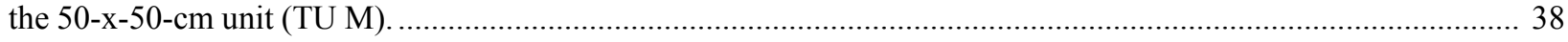

Figure 4-4. Map of Field Site 10 showing locations of auger bores, the backhoe trench, and

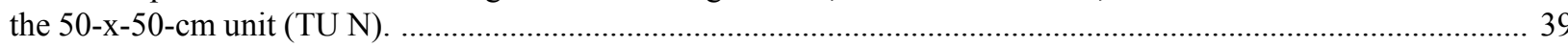

Figure 4-5. Map of Field Site 11 showing locations of backhoe trenches, auger bores and

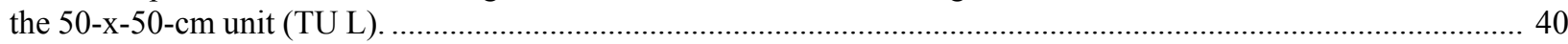

Figure 4-6. Map of Field Site 7 showing locations of auger bores, the shovel test, 50-x-50-cm units, and backhoe

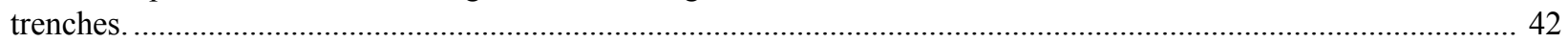

Figure 4-7. Map of Field Site 8 showing locations of auger bores, $50-\mathrm{x}-50-\mathrm{cm}$ units, and backhoe trenches. ................ 43

Figure 4-8. Map of Field Site 9 showing locations of auger bores, 50-x-50-cm units, and backhoe trenches. ................. 44

Figure 5-1. Map of site 41WB635 (FS 2b) showing locations of auger bores, test units, shovel tests,

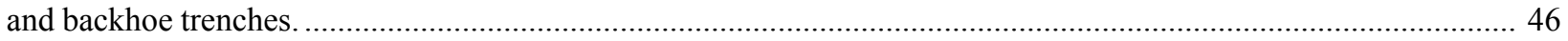

Figure 5-2. Caracara arrow point recovered from 41WB635 (FS 2b)................................................................... 47

Figure 5-3. Biface from southernmost concentration on 41WB635 (FS 2b) ............................................................ 49

Figure 5-4. Standardized mass-specific soil susceptibility values for samples taken adjacent Test Unit E (red) overlaid on standardized artifact numbers from all test units (blue) for 41WB635 ............................................. 52

Figure 5-5. Map of site 41WB637 (FS 5) showing locations of auger bores, shovel tests, the test unit, and

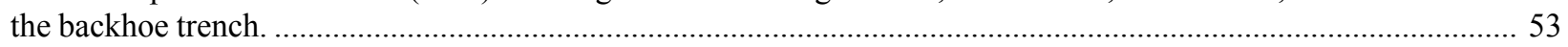

Figure 5-6. Map of site 41WB638 (FS 6) showing locations of test units and backhoe trenches. .................................. 55 
Figure 5-7. Map of site 41WB639 (FS 8b) showing locations of auger bores, 50-x-50-cm units, shovel tests, and backhoe trenches.

Figure 5-8. Tortugas point recovered during Phase II testing at site 41WB639 (FS 8b).

Figure 5-9. Standardized mass-specific soil susceptibility values for samples taken from Test Unit $\mathrm{H}$ and Test Unit J (red) overlaid on standardized artifact numbers (green) for 41WB639.

Figure 5-10. Map of site 41WB640 (FS 11) showing locations of backhoe trenches, auger bores, and the test unit (TU L).

Figure 5-11. Map of the project area showing locations of sites and isolated finds as defined after the Phase II testing. not published 


\section{Tables:}

Table 3-1. Artifacts and Ecofacts Recovered from Field Site 1, by Shovel Test ......................................................... 18

Table 3-2. Artifacts and Ecofacts Recovered from Shovel Tests at Field Site 1, by Level ............................................. 19

Table 3-3. Artifacts and Ecofacts Recovered from Field Site 2, by Shovel Test .......................................................... 20

Table 3-4. Artifacts and Ecofacts Recovered from Shovel Tests at Field Site 2, by Level ............................................. 20

Table 3-5. Artifacts and Ecofacts Recovered from Field Site 3, by Shovel Test ........................................................ 21

Table 3-6. Artifacts and Ecofacts Recovered from Shovel Tests at Field Site 3, by Level ............................................ 22

Table 3-7. Artifacts and Ecofacts Recovered from Field Site 4, by Shovel Test ........................................................ 23

Table 3-8. Artifacts and Ecofacts Recovered from Shovel Tests at Field Site 4, by Level .............................................. 23

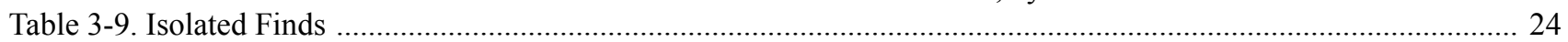

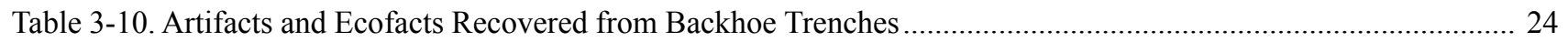

Table 3-11. Correspondence of Field Sites with Backhoe Trenches and Artifact Recovery Data ................................... 25

Table 4-1. Final Depths and Orientation of Backhoe Trenches, Field Site 6 ............................................................... 37

Table 5-1. Correspondence Between Trinomial, Field Site and Provisional Site Numbers ........................................... 45

Table 5-2. Cultural Material from Shovel Tests at 41WB635 (FS 2b) .................................................................... 47

Table 5-3. Cultural Material from Units at 41WB635 (FS 2b) ……..................................................................... 48

Table 5-4. Cultural Material from Auger Bores and Backhoe Trenches at 41WB635 (FS 2b) ..................................... 49

Table 5-5. Vertical Distribution of Artifacts from Units at 41WB635 (FS 2b) ………………................................ 50

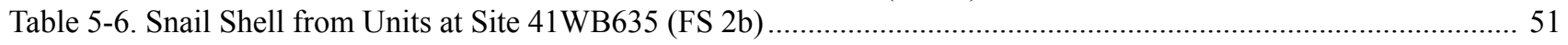

Table 5-7. Vertical Distribution of Adjusted Snail Shell Counts from Units at 41WB635 (FS 2b) .............................. 51

Table 5-8. Cultural Material from Auger Bores and Backhoe Trenches at 41WB637 (FS 5) ....................................... 54

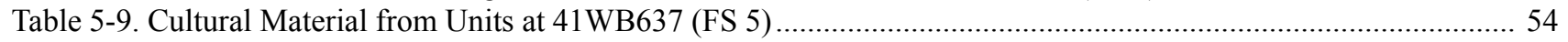

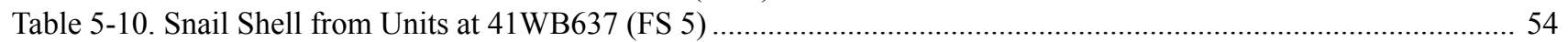

Table 5-11. Vertical Distribution of Snail Shell from Units at 41WB638 (FS 6) ...................................................... 56

Table 5-12. Cultural Material from Auger Bores and Backhoe Trenches at 41WB639 (FS 8b) ................................... 58

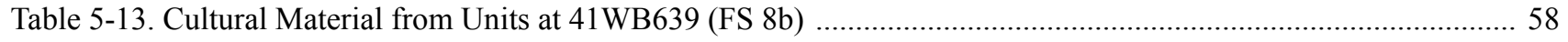

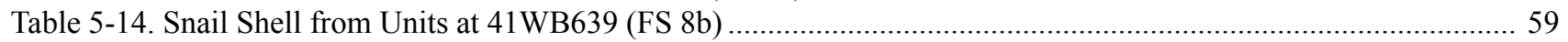

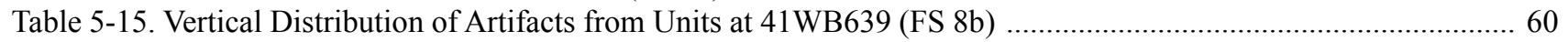

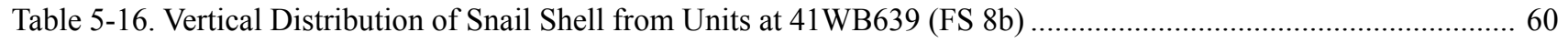

Table 5-17. Cultural Material from Auger Bores, Backhoe Trenches and Units at 41WB640 (FS 11) ...........................63

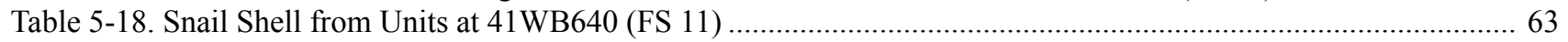

Table A-1. Prehistoric Artifacts Recovered during MACTEC Previous Investigation .................................................... 70

Table B-1. Historic Artifacts Recovered during MACTEC Previous Investigation ...................................................... 72

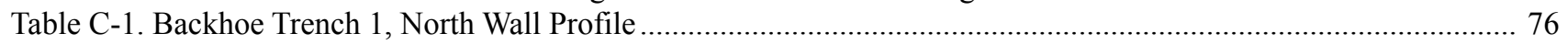

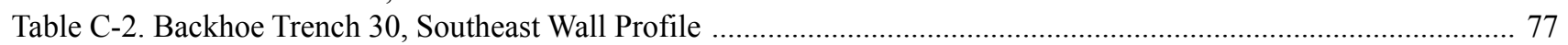

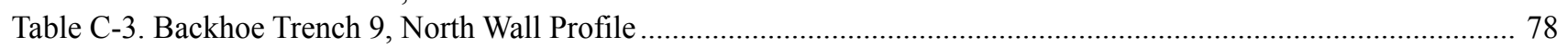

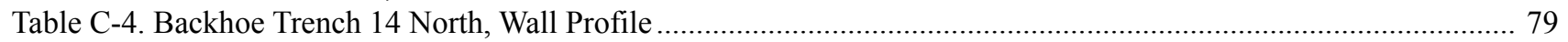

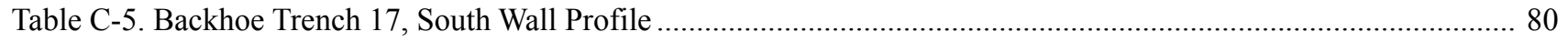

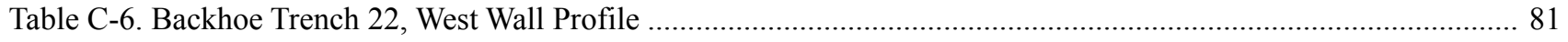

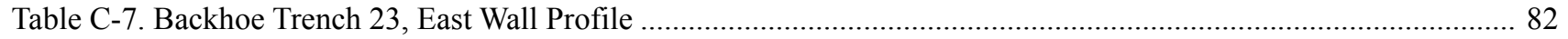

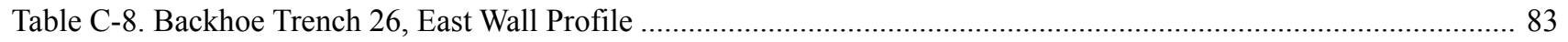

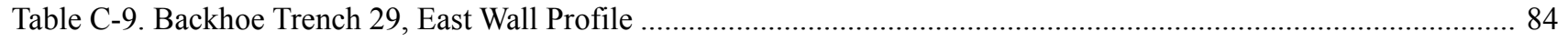

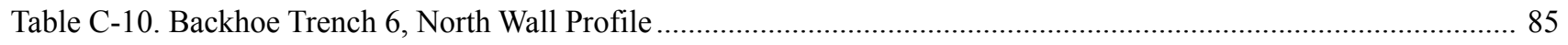

Table C-11. Backhoe Trench 32, North Wall Profile ................................................................................................ 86

Table D-1. Presence/Absence of Cultural Material and Mass Specific Sediment Susceptibility Scores

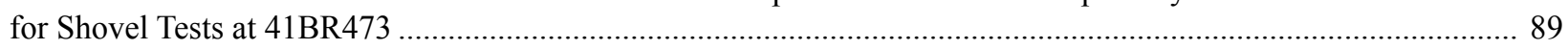

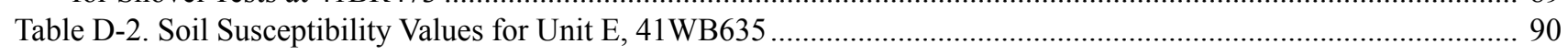

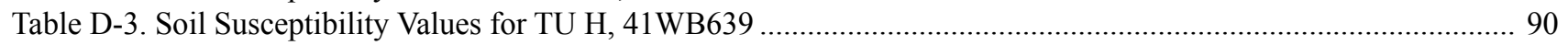

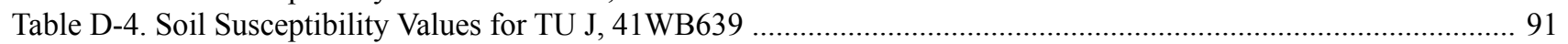




\section{Acknowledgments:}

The successful completion of this project would not have been possible without the assistance of a large number of people. Special thanks go to Robert E. Perry and Dr. Carey B. Oakley of MACTEC Engineering \& Consulting, Inc. who so graciously helped us during fieldwork and provided insightful information and assistance. Thanks also to Scott Evanson, Principal Geologist at MACTEC, for his assistance with contractual matters. Our gratitude also goes to Luis Rubio and Hector Rubio, our machine operators, for their assistance during the auger boring and backhoe trenching processes. Similarly, we would like to thank R. \& J. Environmental, Inc. for their backhoe excavation help on such short notice. Well-deserved recognition goes to the field crew and lab technicians for their hard work during the survey and excavation and processing of the materials obtained during fieldwork. They include the following individuals: Claudia Branton, Leonard Kemp, David Kalinowski, Maggie Moore, Jon Dowling, Cindy Muñoz, Brian Brothers, Lynn Eschenbaun, Linda Martinez, Robert Flournoy, Charles Speer, Bruce Moses, Antonia Figueroa, Kristi Ulrich, Marybeth Tomka, Dr. Raymond Mauldin, and Dr. Steve Tomka. Dr. Russell Greaves served as Project Geoarchaeologist during the survey phase while Antonia Figueroa served as Project Archaeologist. Karla J. Córdova as Project Archaeologist for the Phase II testing. Dr. Raymond Mauldin served as Principal Investigator. Thanks to Bruce Moses and Dr. Raymond Mauldin for the field mapping of the sites. Antonia Figueroa completed the site forms for the project. Bruce Moses and Rick Young produced the graphics for this report and Johanna Hunziker served as technical editor. 



\section{Chapter 1: Introduction}

The Center for Archaeological Research (CAR) of The University of Texas at San Antonio was contracted by MACTEC Engineering \& Consulting, Inc. (hereafter, MACTEC), who in turn were contracted by The GEO Group, Inc., to conduct archaeological investigations involving Phase I intensive pedestrian survey and Phase II National Register of Historic Places (NRHP) eligibility and State Archeological Landmark (SAL) designation testing of sites within the proposed construction area of a detention facility in Webb County, Texas. The survey was conducted on December 13-17, 2004, while the Phase II testing was carried out on March 1-5, March 9-18, and April 2-5, 2005.

The project area is located in Webb County, Texas, approximately 10.5 miles south of the intersection of Interstate Highway 35 and U.S. Highway 83 (Figure 1-1). The Area of Potential Effect (APE) consists of an approximate 30acre footprint within a 160 -acre tract proposed for purchase. The planned facility will include a detention facility with associated parking lots and recreation areas. The impacts within selected portions of the facility footprint where buildings will be erected will extend to a depth of $2 \mathrm{ft}$. below surface. In areas of the facility footprint not affected by building construction, the surface impacts will be limited to the planting of grass cover. Additional Areas of Potential Effect include a 200-meter-wide corridor for storm sewers and sanitary pipes as well as an easement for an access road (Figure 1-2). Subsurface impacts associated with these additional APEs are expected to extend to a maximum depth of $6 \mathrm{ft}$. below surface within a small area at the southern extremity of the utility corridor, where a sewage lift station will be constructed. Subsurface impacts within the proposed access road and utility line corridors are anticipated to extend to a maximum depth of $2 \mathrm{ft}$. below surface.

Section 106 of the National Historic Preservation Act (NHPA) requires federal agencies to take into consideration the effects of proposed undertakings on cultural resources within the APE. While the proposed undertaking is on privately owned property and is funded by private resources, the use of the facility by the United States Marshals Service makes this project a federal undertaking as defined under 36 CFR part 800.16(y). As such, it falls under Section 106 of the NHPA.
The Phase I work consisted of an intensive pedestrian survey of the approximate 160-acre tract proposed for acquisition. Shovel testing and backhoe trenching were undertaken at selected locations to accompany the pedestrian survey. No subsurface investigations were performed within an approximate 28 -acre tract of the property adjacent the Rio Grande (Figure 1-2). This area, investigated using surface reconnaissance only, is located within the Rio Grande 100-year floodplain, and surface disturbances within this area are prohibited without international agreement with the Republic of Mexico. Eleven field sites were documented by the survey work. Of these, eight were tested for NRHP eligibility and possible SAL designation during the Phase II testing.

CAR recommended no additional work at Field Sites 3 and 4 and no Phase II testing was performed at Field Site 1 because the site falls outside the project's footprint and will not be impacted by construction. At the remaining sites, the investigations included hand excavation of test units as well as mechanical auger testing. The testing involved the hand excavation of 1-x-1-meter units on Field Sites 2 and 6, a combination of mechanical augering and a single handexcavated 50-x-50-centimeter unit on Field Sites 5, 10, and 11; and a combination of mechanical augering, backhoe trenching and two hand-excavated 50-x-50-cm units on Field Sites 7, 8, and 9. Five additional backhoe trenches were excavated at Field Site 6 due to difficulties relocating the original backhoe trench (BHT 6).

The results of the investigations suggest that archaeological components with significant research potential, and therefore eligible for NRHP nomination and for formal SAL designation, have been identified on Field Site 8b (41WB639). The site has a buried component that seems to date to the Middle Archaic period, based on the recovery of a Tortugas point at approximately $120 \mathrm{~cm}$ below surface. A low density of debitage was found associated with the buried component, but no features were uncovered. However, the results of the magnetic sediment susceptibility data suggests that this component is associated with a buried surface, enhancing the probability that intact features may be present. Even if no features are present, the recovery of lithic material can contribute to a variety of regional research questions related 


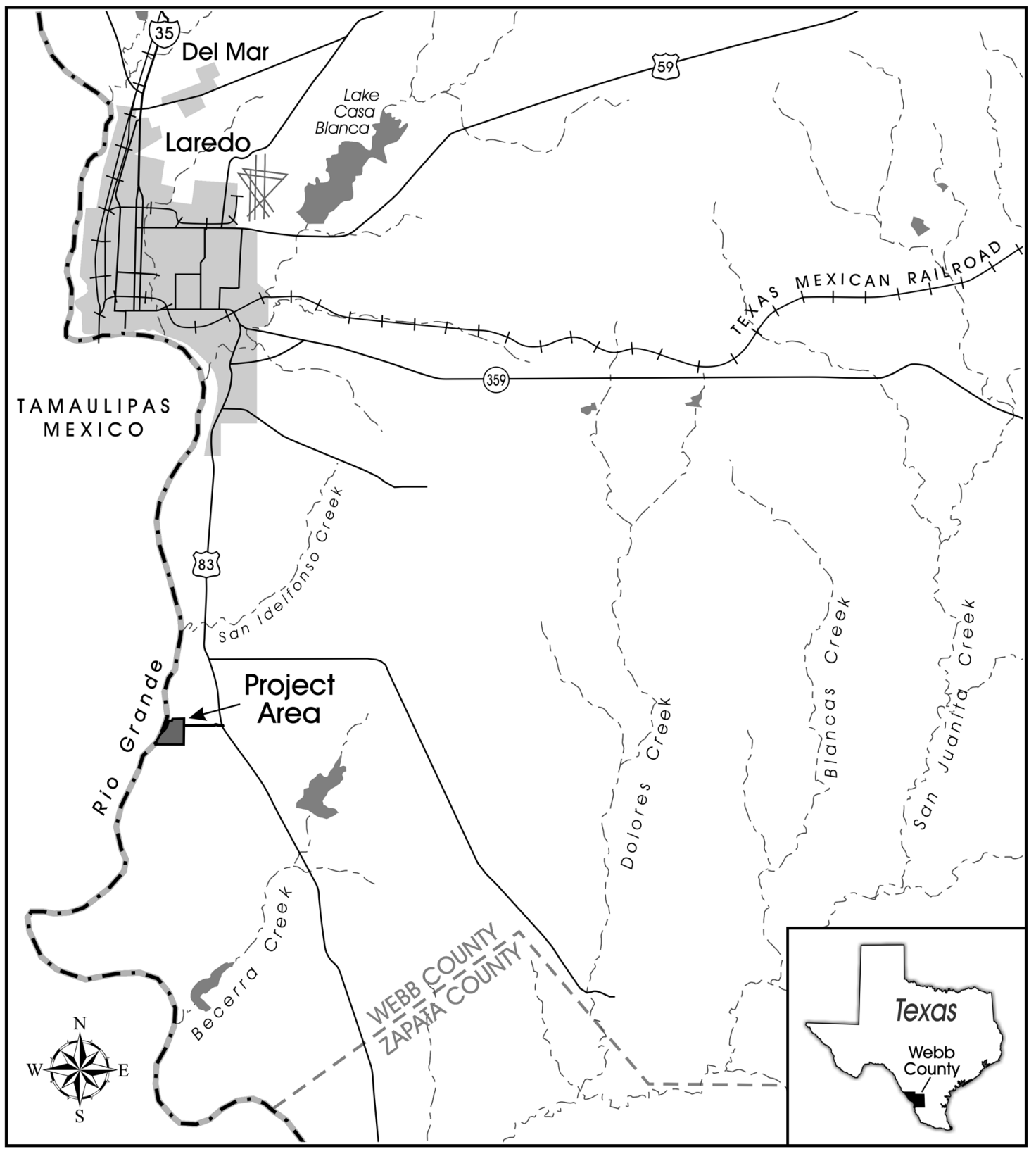

Figure 1-1. General project area location. 
to the Middle Archaic, as the Archaic period has not been well studied in South Texas due to a lack of excavation data and radiocarbon dates (Quigg et al. 2002). Based on the findings within the proposed project area, the site is interpreted as eligible for listing in the NRHP under Criterion D. Likewise, CAR further recommends that the site be designated a SAL under Criterion 1. In addition, archaeological deposits buried below $70 \mathrm{~cm}$ were identified at 41WB637, 41WB638, and 41WB639. The NRHP/SAL eligibility of these deposits has not been fully assessed; however, these sites are located outside of the footprints of buildings and surface disturbances above them will consist of the planting of grass cover. This disturbance will not result in negative impacts to these buried deposits.

The remaining chapters of this report present the methods and results of the survey and testing investigations. Chapter 2 presents background information on the area as well as previous investigations in the area. The Phase I survey investigations carried out by CAR as well as the results of the geoarchaeological work are summarized in Chapter 3. The methods employed during the Phase II investigations are outlined in Chapter 4, while the results and recommendations of these investigations are presented in Chapter 5. Appendices A through $\mathrm{C}$ provide supporting data for the discussions presented in the text. Appendix D presents the results of the standardized mass-specific sediment susceptibility analyses of samples taken from selected locations within the project area. Appendix E is a letter from The GEO Group, Inc. outlining the nature of the surface disturbances in the facility footprint area not subject to building construction.

Site location maps are published in this report due to the sensitivity issues involved with archaeological sites. These maps have been provided to the client and the Texas Historical Commission.

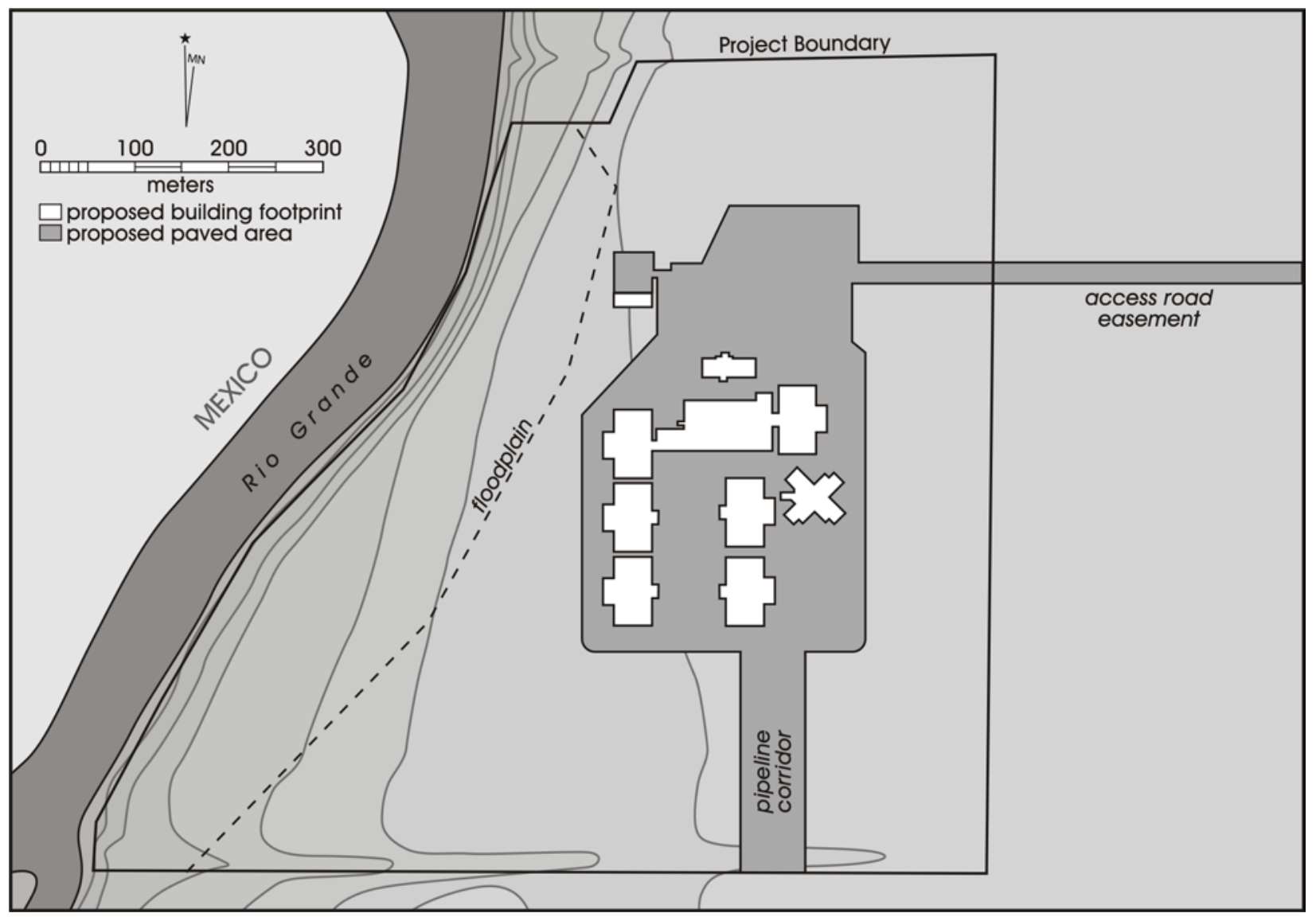

Figure 1-2. Project area with proposed impacts shown. 



\section{Chapter 2: Background and Previous Investigations}

The project area is located south of the city of Laredo on the north-descending bank of the Rio Grande. The locality is situated between $380 \mathrm{ft}$. and $410 \mathrm{ft}$. (116-125 m) AMSL and represents a series of broad, abandoned terraces of the Rio Grande. The northern boundary of the project area runs parallel to, and approximately $30 \mathrm{ft}$. south of, an existing fence line. To the south, the project area is bound by an intermittent stream, to the west by the Rio Grande, and to the east by undeveloped land. During investigations, surface visibility was poor $(<10 \%)$ across the project area due to dense grass cover. In addition, the entire project area was cleared and grubbed by the landowner prior to the initial MACTEC investigations and this was clearly evident from the distribution of large brush piles in the area (Figure 2-1). Fence lines dissect the project area within the floodplain and run parallel to a two-track road. At least two dirt roads were evident on the project area. The land has also been impacted by pipeline installations and ongoing operations of a well that is located in the northwest portion of the property (Figure 2-2).

\section{Environmental Setting}

The project area is located in South Texas in the Rio Grande Valley Region, specifically in the area known as the Western Rio Grande Plain. Presently, the Western Rio Grande Plain is mostly used for cattle and wildlife grazing as well as hunting leases for deer, quail, mourning dove, wild turkey and javelina (Soil Survey Staff 1981). The principal crops are grain sorghum, small grain, cotton and improved pasture (Soil Survey Staff 1981). This chapter presents a summary of the environmental setting of the region to provide a better background for the interpretation of the results of the present investigations.

In general, the topography of South Texas is characterized by gently rolling to flat terrain dissected by intermittent streams (Vierra 1998). Elevation ranges from $50 \mathrm{~m}$ AMSL in the southeast to $300 \mathrm{~m}$ AMSL in the northwest (Soil Survey Staff 1981). The major perennial stream is the Rio Grande, but others run intermittently depending on climatic conditions.

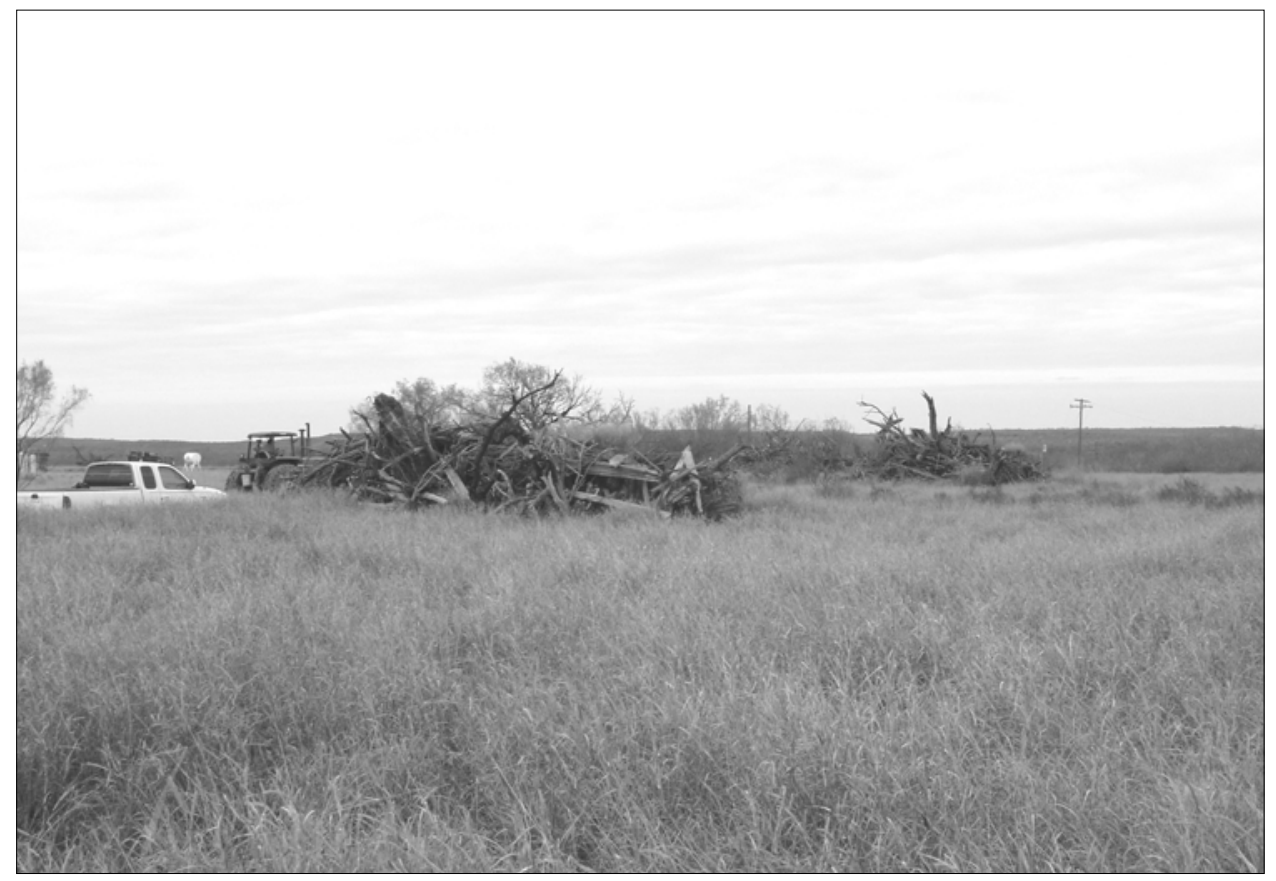

Figure 2-1. Brush piles distributed throughout the project area. 


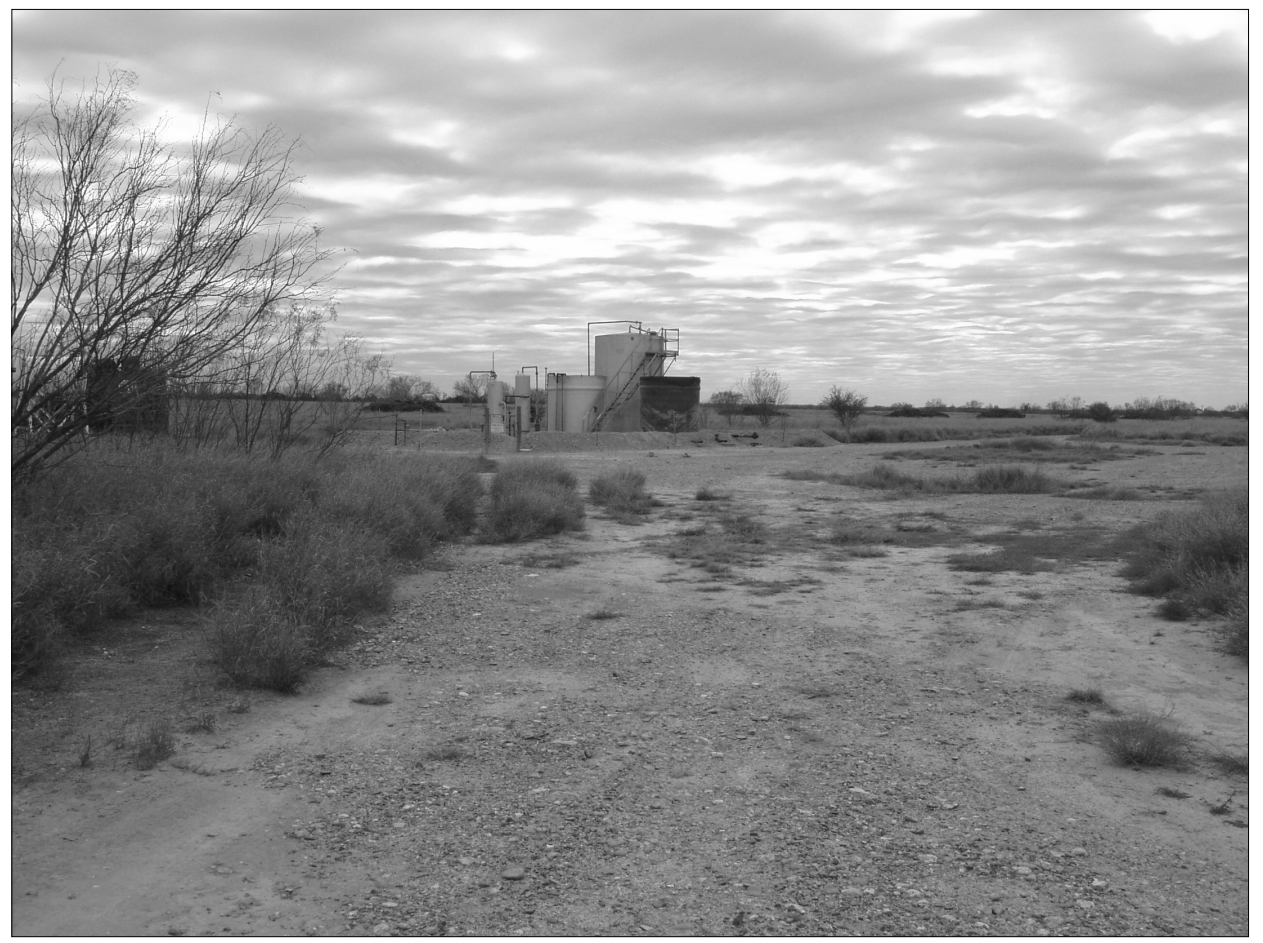

Figure 2-2. Operating well in the northwestern portion of the project area.

\section{Climate and Rainfall}

According to Quigg et al. (2002), the climate of the Laredo region where the project area is located is semi-arid subtropical. Norwine (1995) characterizes the climate of the region as having the following features: 1) a limited amount of available moisture, declining from east to west; 2) extreme inter-annual rainfall variability; and 3) high temperatures and rates of evapotranspiration. The winters in this region are mild with an average temperature of $58^{\circ} \mathrm{F}$ $\left(14^{\circ} \mathrm{C}\right.$; Quigg et al. 2002). Snowfall in the area is uncommon. The average freeze-free period lasts from 260 to 290 days (Soil Survey Staff 1981). The summers in the region are warm, averaging $97^{\circ} \mathrm{F}\left(36^{\circ} \mathrm{C}\right.$; Quigg et al. 2002).

Annual precipitation in the area averages 425 to $525 \mathrm{~mm}$ (Soil Survey Staff 1981). Precipitation is usually greater during the growing season (April to September); however, it is usually not sufficient for cropland and is widely variable from year to year. Rain in the region is frequently associated with tropical storms (Sanders and Gabriel 1985). According to Bomar (1983), Pacific storms and Atlantic hurricanes also produce significant rainfall. Pacific storms occur once every three to five years while Atlantic hurricanes occur once every seven years (Bomar 1983). Humidity is about $60 \%$ and usually increases at night to $80 \%$ (Quigg et al. 2002).

\section{Hydrology}

The Rio Grande and the Nueces River are the major drainages in South Texas along with various small creeks (Figure 2-3). The Rio Grande is located at an elevation of approximately $110 \mathrm{~m}$ AMSL. It drains southeast toward the Gulf of Mexico. The area is surrounded by small creeks, mostly ephemeral along the Rio Grande Valley. These were very likely more numerous and larger in prehistoric times than they are today (Brune 1981). Near Laredo, the Rio Grande has a relatively narrow valley with as many as three alluvial terraces preserved along the valley margins (Quigg et al. 2000). The lower terrace is located north of Laredo and is roughly $120 \mathrm{~m}$ AMSL, whereas the upper terrace is about $128 \mathrm{~m}$ AMSL (Quigg et al. 2000). The sediments that are most likely to preserve archaeological remains in stratified form are the overbank deposits consisting mainly of fine silts and sands located on the Rio Grande terraces (Quigg et al. 2000). Also, there are small creeks along the Rio Grande Valley, some of which have terraces associated with them (Quigg et al. 2000). 


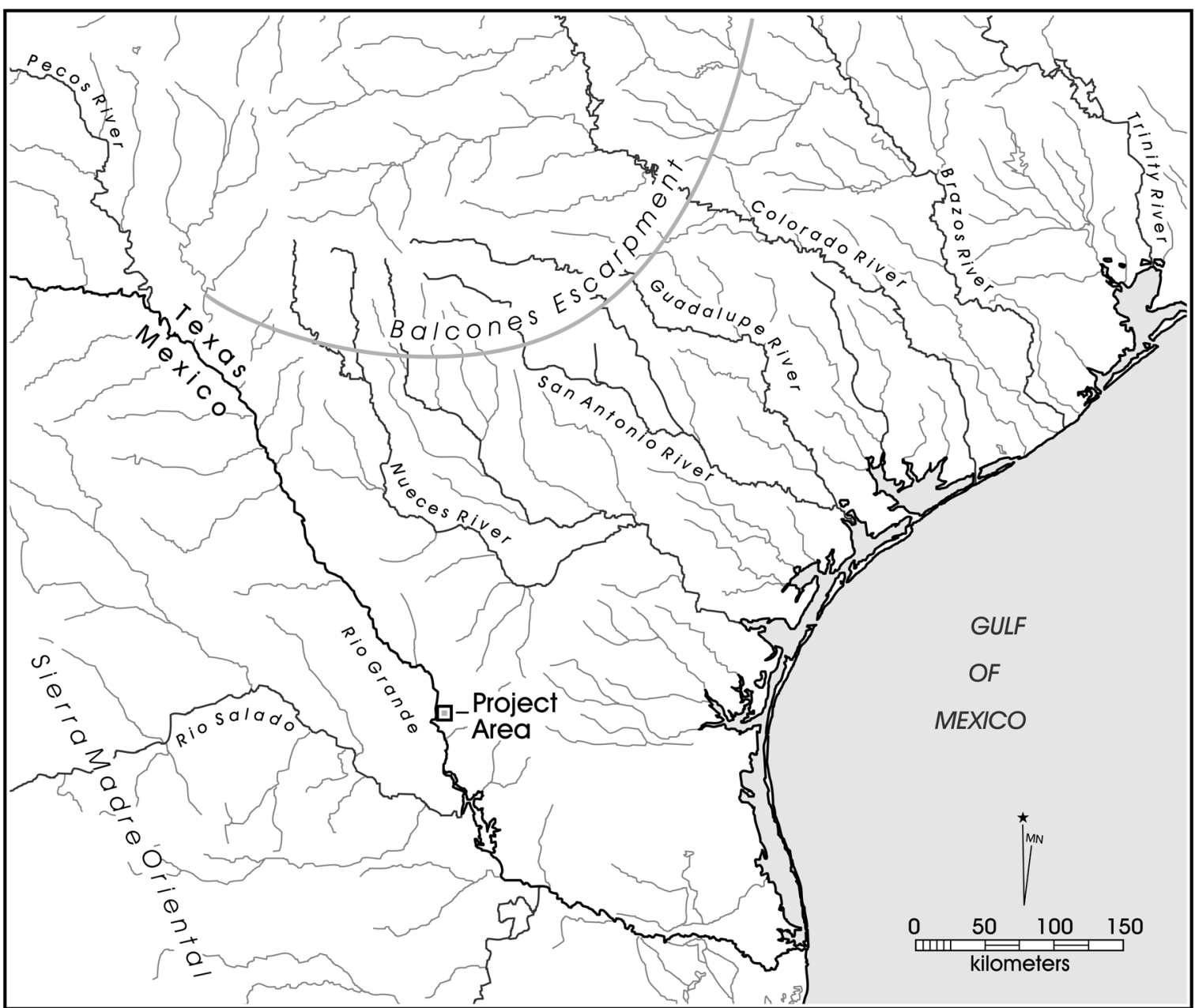

Figure 2-3. Drainages in South Texas.

\section{Geology and Geomorphology}

The general geology of the area has been described by Barnes (1976) as consisting of the underlying Laredo Formation of the Eocene Epoch. Also, Mahoney et al. (2002) described Webb County's geology as primarily dominated by Cenozoic formations beginning with the Paleocene Wilcox and Midway Groups in the northwest and the Miocene Goliad Formation toward the southeast. Uvalde gravels are common in the uplands and on knolls throughout the county (Mahoney et al. 2002). Quaternary terrace deposits in the region, particularly along the Rio Grande, contain a very rich chert-bearing formation. Some chert can also be found in the TertiaryEocene Yegua Formation toward the east-central part of the county as well as in Tertiary-Pliocene Goliad Formation outcrops toward the southwest (Mahoney et al. 2002). Additional raw materials found in the area include petrified wood, chalcedony, and rhyolites.
The lower Rio Grande alluvial valley is a relatively narrow valley incised into Cretaceous and Tertiary strata (Gustavson and Collins 1998). Alluvial deposits can be found along the stream margins and rivers, and are mostly Holocene in age (Quigg et al.2002). Fluvial gravels deposited by the ancestral Rio Grande can also be found in some upland areas. According to Gustavson and Collins (1998), terrace-filling alluvium and floodplain sediments are preserved in the Rio Grande's alluvial valley, but valley incision and sediment transport are the dominant geomorphic processes. The Rio Grande terraces and floodplain alluvium has been described in detail by Gustavson and Collins (1998). The following summary is extracted from that source.

The Rio Grande's alluvial valley is in general less than two kilometers wide with alternating terrace and floodplain alluvium and high bluffs. Three terraces are preserved in the upstream Rio Grande region. High terraces in this part 
of the river valley lie as much as $20 \mathrm{~m}$ above the river at low-flow stage. The subsection where the project area is located is characterized by a $0.4 \mathrm{~m} / \mathrm{km}$ slope and a sinuosity of 1.3. The narrow valley cuts into Eocene clastic sediments of the Kincade, Indio, and Carrizzo formations. Soils in recent Rio Grande alluvium include the Rio Grande and Camargo series soils that develop on the silts and sands of natural levees, and the Matamoros Series soils on the flood basin muds. Rio Grande and Matamoros soils are calcareous and relatively immature soils that have not developed horizons. Lagloria, Reynosa, and Laredo series soils are developing on the older alluvium of intermediate and high terraces. These characteristically thick soils are more mature with shallow horizons containing accumulations of calcium carbonate $\left(\mathrm{CaCO}_{3}\right)$ nodules.

In general terms, the project area is located on the eastern bank of the Rio Grande at elevations of approximately 380 $410 \mathrm{ft}$. (116-125 m) AMSL. The area represents a series of broad, abandoned terraces of the Rio Grande. The proposed facility is situated on the $T_{8}-T_{10}$ surfaces and the proposed roadway ascends to older terraces terminating at the eastern margin of $\mathrm{T}_{12}$. These terraces contain primarily low-energy deposits. The sediments are mostly fine, well-sorted silt loams, loams or clay loams with very few siliceous gravels. The project area consists of deep silt loams that are primarily Lagloria Series soils (Sanders and Gabriel 1985:27-29, 79, Sheet 89) overlying Laredo Formation Eocene sandstones (Groat 1976). The proposed roadway is located across the Laredo Series silty clay loams and Copita fine sandy loams soils (Sanders and Gabriel 1985:22, 29, 74, 79). More detailed geomorphologic descriptions of the project area are presented in Chapter 3 of this report.

\section{Vegetation and Fauna}

The Laredo area is located in the South Texas Brush Country which is part of the western Tamaulipan Thornscrub biotic province (Blair 1950). Figure 2-4 shows the vegetation provinces of Texas. In general, the Tamaulipan Thornscrub biotic zone is characterized by thorny brush including mesquite (Prosopis glandulosa), various species of acacia and Minosa, granjeno (Celtis pallida), lignum vitea (Porliera angustifolia), cenizo (Leucophyllum texanum), white brush (Aloysia texana), prickly pear (Opuntia lindbeimeri), tasajillo (Opuntia leptocaulis), and Condalia and Castela (Quigg et al. 2000). It is not known when the area became dominated by thorny brush vegetation, but in general terms, the vegetation of the area as well as the fauna have been greatly modified during the historic period. The early descriptions of the area suggest that the Rio Grande Valley was covered by forests of willow, cottonwood, and others while the banks of the river lack trees (Inglis 1964:98). Later observations made by Sanchez and Bandelier in 1828 and by Hendricks in 1842 describe the Rio Grande area in the vicinity of Laredo as without trees and containing mostly mesquite with some huisache and cactus (Quigg et al. 2000). According to Hester (2004), mesquite has been present in the area since $6000 \mathrm{BP}$ and the riverine environment present today has been in place since approximately $2250 \mathrm{BP}$.

The faunal diversity of the area has also been significantly altered, resulting in the disappearance of various species such as bison, pronghorn antelope, bear, wolf, and jaguar. These were present in the area up to the beginning of the twentieth century (Doughty 1983:54, 76). On the other hand, species have also been added to the region. Some of the introduced species include armadillo and javelina (Hester 2004). The fauna of the Tamaulipan province is substantial. Blair (1950) mentions at least 61 different species of mammals, 36 species of snakes, 19 lizards, two species of land turtles, 19 species frogs and toads, and three species of urodels. There are also numerous invertebrate species including bivalves.

\section{Paleoenvironment}

Preservation conditions in South Texas are poor because of high soil $\mathrm{pH}$ and low organic content (Vierra 1998). As a result, the information available to reconstruct paleoenvironmental conditions is limited. Various data sets have been used to describe the prehistoric environment of South Texas, but more precise dating is needed to clarify the timing of specific climatic events. Generally, the data for Central Texas is used to describe the paleoenvironment of South Texas as the pattern appears to be applicable. Vierra (1998) outlined a general paleoenvironment for South Texas. The following summary is extracted from this source.

The environment from ca. 12,000 to $800 \mathrm{BP}$ was characterized by mesic conditions associated with the end of the Pleistocene and the beginning of the Holocene. Xeric conditions appeared about 8000-4500 BP with a period characterized by increased moisture around $6000 \mathrm{BP}$. The Altithermal (5000 BP) was characterized by extreme dry and warm conditions. Mesic conditions returned about $4500 \mathrm{BP}$ and have lasted until the present. 


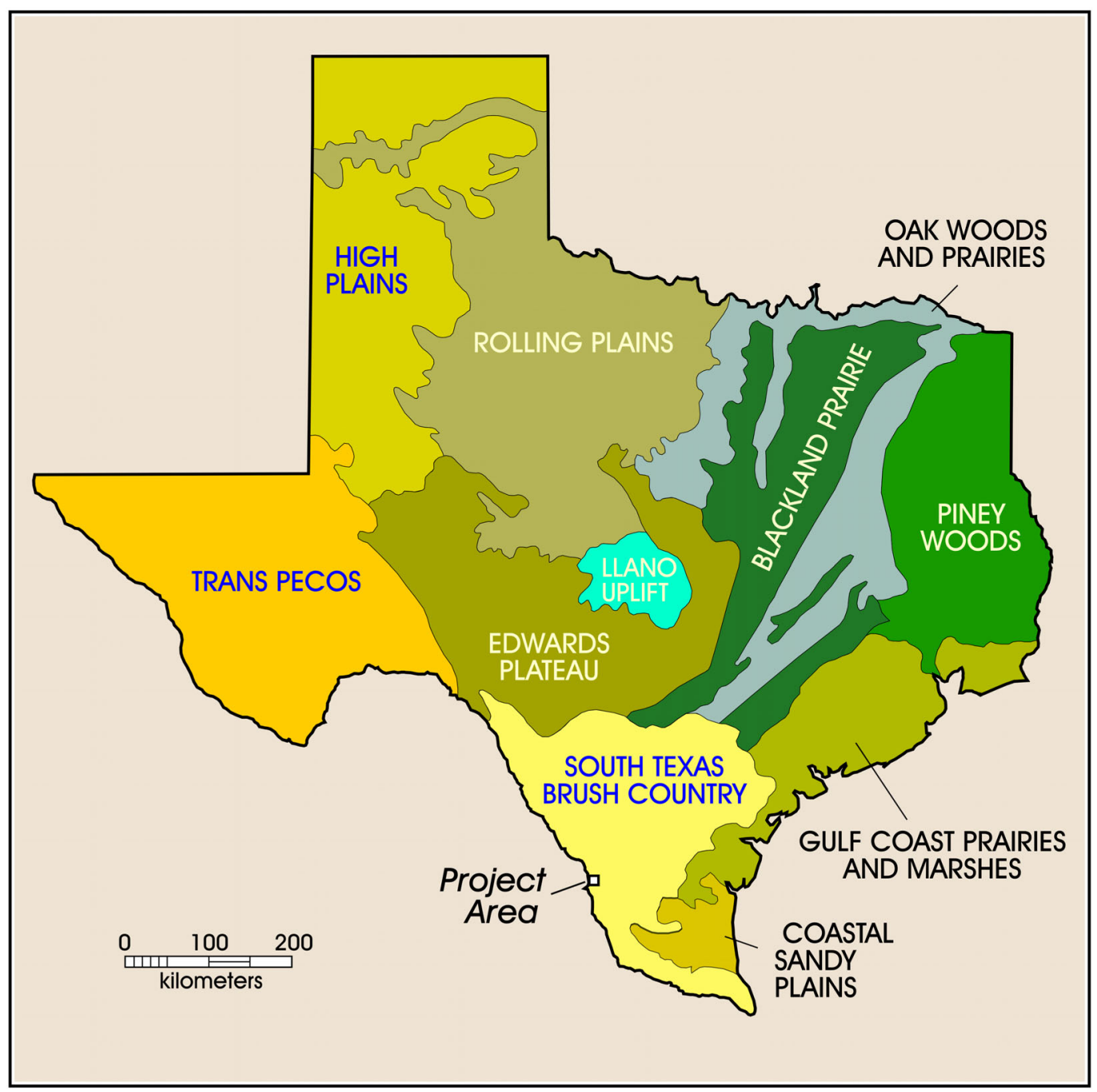

Figure 2-4. Vegetation provinces of Texas.

\section{Cultural Background}

This section summarizes the prehistoric cultural setting for South Texas. This summary is primarily based on a recent, more comprehensive review by Hester (2004). Additional descriptions of the cultural development of South Texas can be found in Black (1989a, 1989b), Collins (1995), Hester (1995), and Turpin (1995). It is important to remember that much of what is known about the prehistory of South Texas is correlated with data from Central Texas, as the chronologies appear to be very similar. Likewise, the chronologies for South Texas are not very well known due to the lack of intensive excavations in the area. For the purposes of this report, the South Texas Cultural Region boundaries are the Balcones Escarpment to the north, the Rio Grande to the west and the Guadalupe and San Antonio rivers to the northeast. The southern boundary is at the mouth of the Rio Grande. The native groups in this region disappeared in the eighteenth century as a result of Spanish-introduced diseases, raiding by Apaches and Comanches, the missionization process, and acculturation (Hester 1989). In general terms, the prehistory of South Texas can be divided into Paleoindian, Archaic, Late Prehistoric, and Protohistoric periods. 


\section{Paleoindian}

The earliest occupations in South Texas began around 11,200 years ago and are represented by Clovis and Folsom points. No mammoth kill or butchering sites have been reported in South Texas. The late Pleistocene fauna and associated lithics found in the Berclair Terrace in Goliad and Bee counties remain enigmatic (Sellards 1940). Clovis points have been found in Wilson, Dimmit, and Atascosa counties. Folsom artifacts are also common in the area of the Rio Grande Plain, specifically in Webb County and near Falcon Reservoir. The most intriguing Paleoindian site excavated in the area is Berger Bluff(41GD30) in Goliad County dating to $9500 \mathrm{BP}$. The site included a hearth, a chipping area, two pits, cores and a biface. Late Paleoindian projectile point types are common in South Texas, but their typologies are problematic since it is hard to distinguish between some of the types (such as Golondrina and Plainview). As a result, characterizing the different stages of the late Paleoindian is difficult as well.

\section{Archaic}

Early Archaic adaptations in South Texas are poorly known and documented, in part, due to the lack of deeply stratified archaeological sites within the region. This period is usually divided into two horizons - the early corner-notched and the early basal-notched (Hester 1995). The early cornernotched period is not very well known, but in general is typified by corner-notched dart points with recurved or notched bases. It is believed that the peoples of this time period were highly mobile and operated in small bands. The temporal span for this time period, based on typological cross-dating, is believed to be from ca. 6000 to 3500 B.C. Occupations associated with this time period are found in Travis County, Choke Canyon Reservoir, on the terraces of Chaparrosa and Turkey creeks, and along the Rio Grande and Nueces rivers.

The subsequent early basal-notched horizon is characterized by specimens with deep basal notches, large barbs, and distinctive long stems. Other recognizable traits of this horizon include large, unifacial Clear Fork tools, smaller forms, and multi-notched Bell/Andice specimens. The early basal-notched horizon dates roughly to $3600-3000$ B.C. This horizon extends from the southern Texas coast, across the Rio Grande Plain, and into northeastern Mexico east of the Sierra Madre Oriental. Specimens from this horizon have been reported in Victoria County, at the mouth of the Nueces River, and at Falcon Reservoir.
The Middle Archaic is characterized by the development of regional patterns. The onset of this period was around 2500 B.C. lasting to about 400 B.C. In general, this period is characterized by unstemmed dart points and smaller unifacially and bifacially beveled tools. Some of the most common artifacts are Tortugas and Abasolo dart points. Assemblages from this time period have been found along the Rio Grande between Falcon Reservoir and Eagle Pass. Cemeteries are also associated with this time period, especially in the later part of the sequence (ca. 800-600 B.C.). Grave goods associated with cemeteries include triangular dart points, marine shell, tabular pieces of sandstone, and tubular sandstone pipes.

The Late Archaic dates from 400 B.C. to around A.D. 600/ 700. Characteristic material for this period includes Shumla, Ensor, Marcos, and Montell points as well as Olmos bifaces and small, triangular gouge-like tools. Grinding implements such as manos and metates are also characteristic of this period in South Texas. A high percentage of the material from this time period is made of heat-treated chert. The presence of manos and metates suggests an increase in the use of plant products such as mesquite and acacia beans. Sites of this time period are almost always located adjacent present stream channels or sloughs.

\section{Late Prehistoric}

The Late Prehistoric in South Texas has been largely correlated to its Central Texas counterpart. Based on that, Edwards and Scallorn points represent the first diagnostic artifacts of the period. A distinctive artifact of this period is the arrow shaft straightener. Pottery was also introduced during this period. The Toyah horizon (A.D. $1250 / 1300$ to $1600 / 1650$ ) is the bestdocumented Late Prehistoric pattern. In South Texas it is represented by Perdiz points, small end scrapers, flake knives, beveled knives, bone-tempered pottery, pipes, ceramic figurines, bone objects, and shell ornaments.

The culture history of the Rio Grande delta area during the Late Prehistoric is intriguing. The cultural pattern present at the time in the area is known as the Brownsville Complex (A.D. 1100-1700). The Brownsville Complex groups located their sites on clay dunes and were hunters, gatherers, and fishers. Use of shell ornaments was widespread during the period, but little else is known about groups composing the Brownsville Complex. Ollas and jadeite and serpentine artifacts have been found associated with the Late Prehistoric in the Rio Grande delta. These finds, in combination with the origin of obsidian artifacts 
found in association with Brownsville Complex sites (Figure 2-5), suggest trading with the Huastecan culture and a connection with central Mexico.

Following the Late Prehistoric, there was a transitional period between the prehistoric period and the historic period for which few written records are available. This period is called the Protohistoric, and in South Texas it covers the sixteenth and seventeenth centuries, before the economy of the groups inhabiting the area was impacted by Spanish explorers and the mission system. This period has not been well studied; therefore it is hard to make generalizations to describe it. Nevertheless, it is believed that the Protohistoric is a continuation of the previous period, as the sporadic European entries had no lasting effect on the economies and cultures of the groups inhabiting South Texas.

\section{Previous Investigations}

Various authors (e.g., Black 1989a; Hester 1995, 2004; Quigg and Cordova 2000; Quigg et al. 2000; and Quigg et al. 2002) have summarized the archaeology of extreme South Texas. However, much still remains to be learned about South Texas prehistory due to limited excavation

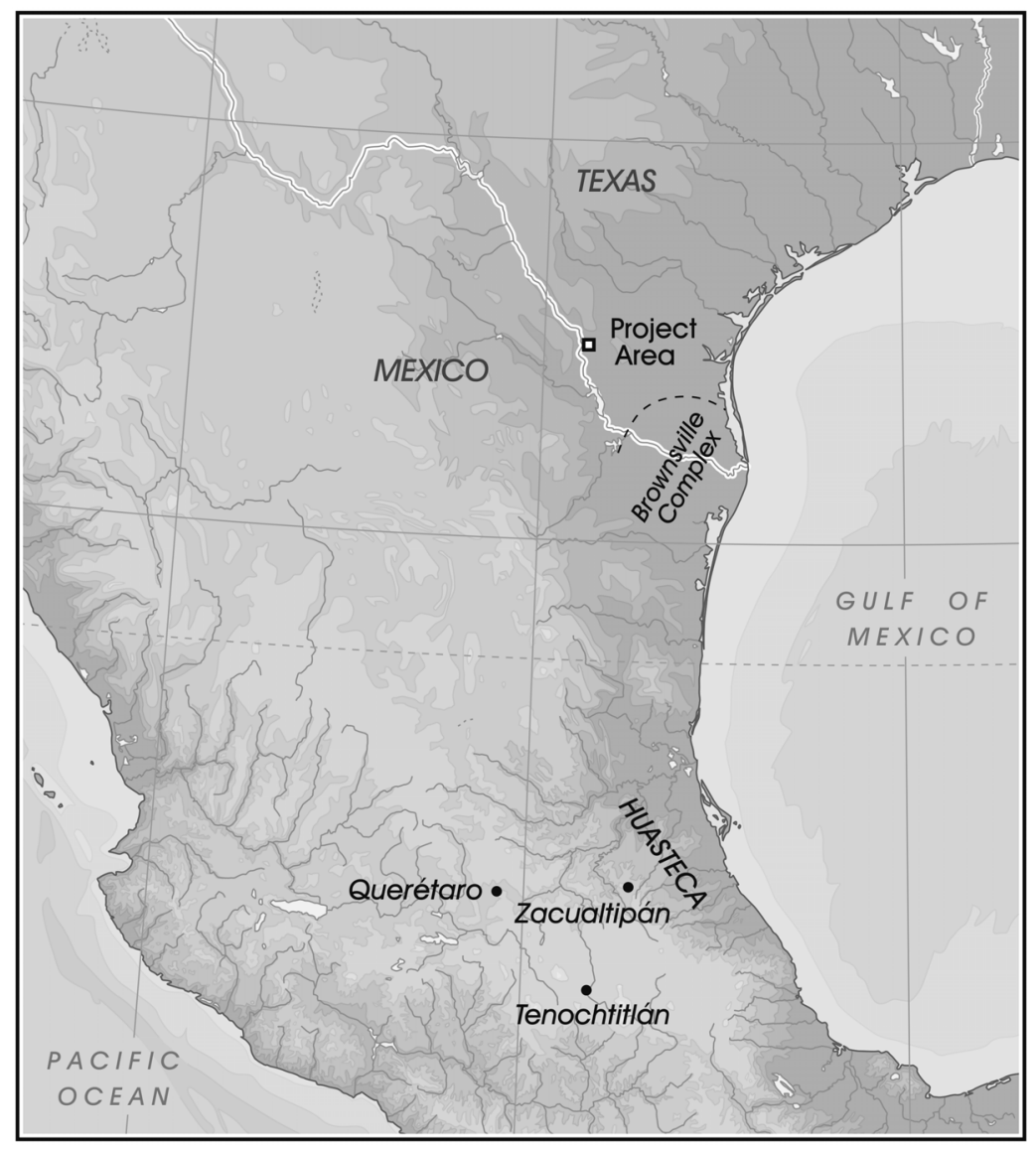

Figure 2-5. Map showing locations of geologic sources of obsidian from the Huasteca Region found in Brownsville Complex sites. projects and radiocarbon dates. The first professional archaeological investigations in the region started in the 1950s associated with the construction of Falcon Reservoir along the Rio Grande (Mahoney et al. 2002). However, even though investigations in the area started in the 1950s, a limited amount of work was performed in the area until the 1970s (Mahoney et al. 2002).

One of the first and few excavated sites in extreme South Texas was 41SR42 dug by Hartle and Stephenson (1951) as part of the Falcon Reservoir salvage project. Excavations at this deep, stratified site yielded many stone tools including 28 Tortugas points as well as flakes, charcoal, burned earth, intact hearth features, and limited amounts of bone (Quigg and Cordova 2000). Subsequently, a number of larger survey projects proliferated in the region. These include the investigations at Choke Canyon Reservoir by Brown et al. (1982) and Hall et al. (1982 and 1986). The Choke Canyon investigations have provided an estimated chronological sequence for the region based on the radiocarbon samples collected (Quigg et al. 2002). Investigations associated with Interstate Highway 37 at Loma Sandia also contributed to the advance of archaeology in the region (Taylor and Highley 1995). Likewise, some testing projects and surveys in Webb County have contributed to the archaeological knowledge of South Texas.

One of the first testing projects in Webb County was conducted at 41 WB206 by the Texas Department of Transportation as part of the Laredo-Colombia International Bridge (McGraw and Thompson 1998). The project recovered surface and subsurface material buried to a depth of $3 \mathrm{~m}$ with humate dates ranging from 3350 B.C. to the fifteenth century A.D.; however, the research potential of the site was limited (Mahoney et al. 2002). An emergency exhumation project at the Laredo cemetery (41WB22) was conducted by McReynolds in 1981, but the first data recovery project in the county was the excavations at the Lino Site (41WB437) by TRC Mariah in 1998 (Quigg et al. 2000). This data 
recovery project was followed by SWCA's mitigation of 41WB314 conducted as part of the Camino Colombia Toll Road project (Miller et al. 2000). Excavations at and in the vicinity of $41 \mathrm{WB} 314$ have provided some information regarding upland sites in South Texas. Testing and subsequent mitigation of the Boiler Site (41WB557) was performed by TRC Mariah in 2000 (Quigg et al. 2002). Subsequently, the Center for Archaeological Research completed data recovery along Becerra Creek, specifically at site 41WB556, during the summer of 2000 (Mahoney et al. 2002).

In general terms, the archaeology of South Texas and Webb County has been studied through a variety of data recovery efforts as well as surveys. There are a large number of sites recorded in the county, nevertheless, the archaeology of the region as well as the county is still not well understood. Some time periods (i.e., Archaic) have been better studied than others. For example, little is known about the Late Prehistoric period in Webb County (Mahoney et al. 2002). As is the case for the South Texas region in general, information from other regions has been used to fill the gaps in our understanding of the prehistoric adaptations in the area.

\section{Previous Investigations in the Immediate Vicinity of the Project Area}

MACTEC conducted background research investigations for the area in the general vicinity of the project area considered for this study. The following summary of previous work in the area is extracted from MACTEC's review of the National Register of Historic Places database and the archaeological files maintained by the Texas Archeological Research Laboratory at The University of Texas at Austin (Perry 2004).

Several archaeological investigations have been conducted in the general vicinity of the proposed project area. Of these, the most significant was a regional study of the Rio Grande alluviums by Gustavson and Collins (1998). In general, they concluded that the deposits along the Rio Grande were predominantly Holocene in age and that the depositional processes have exceeded the erosional processes creating a positive archaeological bias. The next significant investigation in the area was a reconnaissance-level survey conducted in 2003 by Parsons, Brincherhoff, Quade and Douglas, Inc. Their project was located in the property adjacent and north of the current project area. A total of nine archaeological sites was recorded (41WB590 through 41WB598). Three of these sites were recommended as having potential for intact subsurface deposits. One of these sites was dated to the Late Archaic and Late Prehistoric while the other two were dated to the Middle to Late Archaic periods.

Subsequently, Robert Perry of MACTEC conducted a preliminary cultural resources assessment of the current project area for The GEO Group, Inc. that included a review of the National Register of Historic Places database, archaeological files maintained by the Texas Archeological Research Laboratory, historic maps, and aerial photographs (Perry 2004). Field methods employed during the investigations included a pedestrian reconnaissance, surface observation, and the excavation of limited shovel tests (Perry 2004). During the MACTEC investigations, five provisional archaeological sites were identified within the project area (Figure 2-6, not published). Lists of cultural material recovered during the MACTEC investigations are provided in appendices A and B.

Provisional Site Number 1 was described as a prehistoric site with a moderate surface scatter of lithic debitage. Three of the eight shovel tests excavated on site were positive. They revealed that the cultural deposits reached a depth of $27 \mathrm{~cm}$ below surface (cmbs). No diagnostic cultural material was recovered from the site. The cultural material recovered from the shovel tests consisted of lithic debitage $(n=3$; Appendix A).

Provisional Site Number 2 was identified as a multicomponent site, delineated solely by surface artifacts. The historic component consisted of decorated and undecorated ceramic sherds (lead-glazed, white earthernwares, and stonewares), nails, and glass (aqua, amber and purple; Appendix B). The prehistoric component consisted of a scatter of lithic debitage (Appendix A).

Provisional Site Number 3 was identified as a prehistoric site consisting of a light scatter of lithic debitage present along a north-south running fence line. The site was delineated solely on surface representation. Provisional Site Number 4 also was identified along a surface disturbance that ran north-south and consisted of a moderately dense scatter of lithic debitage and a late reduction stage biface. Provisional Site Number 5, also a prehistoric site, was a sparse surface distribution of lithic debitage and natural gravels (Appendix A). No diagnostic artifacts were identified on any of the sites. Given the planned preliminary nature of the assessment, no shovel testing was performed on these three sites so the depth of the cultural deposits remained unknown. 


\section{Chapter 3: Phase I Intensive Pedestrian Survey and Geoarchaeological Investigations}

During the week of December 13-17, 2004, CAR conducted an intensive pedestrian archaeological survey of the approximate 160-acre tract proposed for acquisition. Within the APE of the proposed undertaking, the survey was accompanied by shovel testing and backhoe trenching at selected locations. In the area representing approximately 28 acres located within the active Rio Grande floodplain, no subsurface investigations were conducted and the work was limited to surface reconnaissance.

\section{Pedestrian Survey Methods}

On December 13, 2004, the entire 160-acre tract was traversed prior to the commencement of shovel testing due to uncertainty about the location of the floodplain boundary. During the pedestrian survey, crews traversed the project area along 30-m transects that were oriented east-west. There were 28 transects, each was flagged at its starting and ending points for relocation purposes. Aerial photographs with clearly marked transects and hand-held compasses were used to orient crew members along each survey transect. The limits of the floodplain that were to be the subject of surface reconnaissance and the boundaries of the project area, the facility footprint, and pipeline and access road easements were delimited on December 14 by mowing paths around the perimeter and inserting stakes at the corners. Refer to Figure 1-2 for the boundaries of the project area including the location of the facility footprint, pipeline, and access road easements.

When there was evidence of a surface distribution of cultural material during survey it was marked with flagging tape. In addition, the beginning and ending points of the distribution were mapped with a Trimble GeoExplorer II Global Positioning System (GPS) unit.

For the purpose of this survey, a site was defined as a location containing either (1) five or more surface artifacts within a 15 -m radius (ca. $706.9 \mathrm{~m}^{2}$ ) or; (2) a location containing a single cultural feature, such as a hearth, either on surface or exposed in a shovel or auger test or; (3) a location with a positive shovel test or backhoe trench containing at least three artifacts within a given 10-cm level or section of trench or at least four artifacts within any auger level $(40 \mathrm{~cm})$ or;
(4) a location with a positive shovel or auger test containing at least five total artifacts or; (5) two positive shovel or auger tests or two positive backhoe trenches located within $30 \mathrm{~m}$ of each other. All other artifacts were classified as isolated occurrences or finds.

During the survey, shovel tests were excavated in accordance with the Texas Historical Commission's archaeological survey standards at an average of one (1) shovel test for every (3) three acres. The shovel tests were spaced such that consistent coverage was achieved within the survey area. Only temporally or technologically diagnostic artifacts (i.e., projectile points, scrapers, gouges, etc.) were collected from the surface during this survey. Prior to collection, the position of any such artifact was mapped with a GPS unit. At the request of the landowner, all collected artifacts will be returned following analysis and publication of this report.

When cultural material was encountered in a shovel test, the unit was deemed positive and was marked with pin flags or flagging tape. All shovel test locations were recorded using a GPS unit. Shovel test locations were also sketched onto topographic maps or aerial photographs as a backup to GPS provenience information. Any additional observations considered pertinent were included as comments on the standard shovel test excavation form.

Following the initial survey of the APE, the crew was to return to positive shovel tests to excavate additional tests in their vicinity. Unfortunately, several positive shovel tests could not be relocated and no additional shovel tests were excavated in their vicinity. These shovel tests will be briefly mentioned in the discussion of the survey results.

Shovel tests were $30 \mathrm{~cm}$ in diameter and were excavated to a maximum depth of $60 \mathrm{~cm}$ below surface, unless otherwise prevented from reaching this depth. All shovel tests were excavated in arbitrary $10-\mathrm{cm}$ levels. Deposits from these tests were screened through $1 / 4$-inch mesh, all artifacts were collected, and observations on the shovel tests were recorded on standardized forms. A shovel test form was completed for each excavated shovel test. Data collected from each shovel test included the final excavation depth, a tally of all materials recovered from each $10-\mathrm{cm}$ level, and a brief soil description (texture, consistence, sediment color, inclusions). 
When new sites or the previously recorded provisional sites were encountered during survey, shovel tests were excavated within the vicinity of the previous positive shovel tests and/ or surface scatter of materials to define the extent of the distribution (i.e., site boundary). Between six and ten additional shovel tests were excavated to define a site's boundary. Using the site definition presented previously, once an artifact concentration was identified as a site, crew members established a datum consisting of a length of rebar hammered into the ground at the site's center. Using the GPS units, CAR surveyors took readings from the datum of the site, all features, and from sufficient points along the perimeter to define the site boundary. Diagnostic artifacts were collected and their locations recorded with a GPS unit. In addition, sketch maps were drawn showing site boundaries, datum locations, shovel tests, collected items, features, areas of high artifact density, and physical features on the landscape. Archival-quality digital color photographs were made of all sites and artifacts when appropriate.

If artifacts did not constitute a site, they were classified as isolated occurrences or finds. In all cases, isolated finds were recorded on separate forms prepared for this project and their locations were mapped using GPS units. As with onsite surface finds, only diagnostic artifacts were collected from surface. On the other hand, all artifacts derived from shovel tests were collected by provenience and returned to the CAR laboratory for analysis.

\section{Backhoe Trenching Methods}

Based on the types of impacts expected across the project area, backhoe trenching was proposed in three distinct parts of the project area: (1) the facility footprint; (2) the easement of the sewer and sanitary water lines; and (3) the access road entering the 160 -acre site.

Trenches within the proposed facility footprint were excavated to a target depth of $2 \mathrm{~m}$ below the current ground surface (Figure 3-1). The 2-m-deep trenches within the proposed detention facility footprint were excavated with a bench approximately $1 \mathrm{~m}$ deep on the southern side to permit safe examination of these deep alluvial soils. All trenches excavated along the proposed roadway route and storm sewer lines were excavated to a target depth of $1.5 \mathrm{~m}$ below surface. Each trench was approximately $1 \mathrm{~m}$ wide and was targeted to be approximately $5 \mathrm{~m}$ long. All trenches within the proposed facility and sewer line areas were excavated east-west, perpendicular to the course of the Rio Grande. Trench orientation permitted maximum examination of any temporal variation in floodplain deposits. Trenches

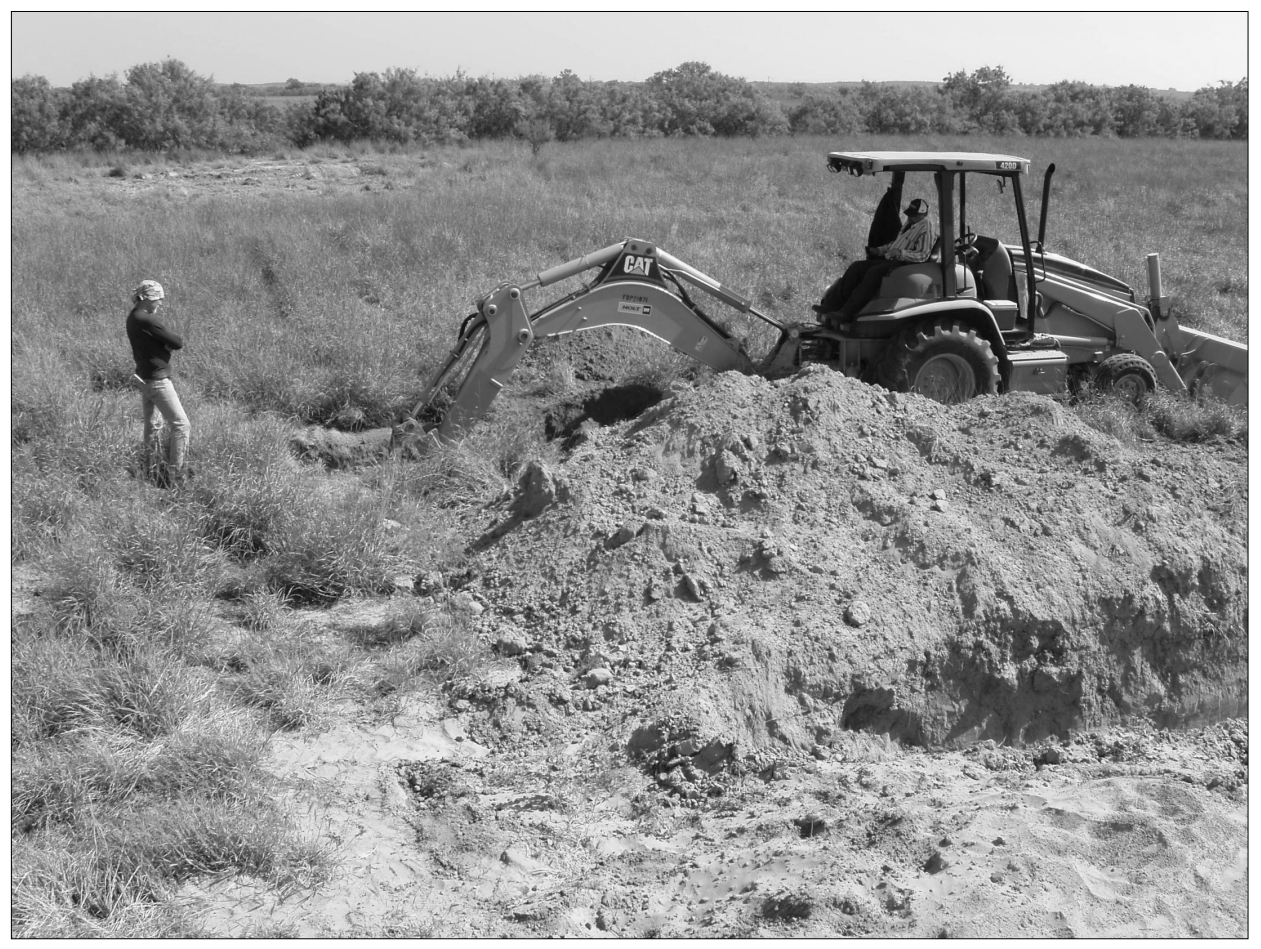

Figure 3-1. Backhoe trenching activities, Backhoe Trench 6-4 at Field Site 6. 
excavated along the proposed access road were oriented north-south and centered on the indicated centerline to maximize the probability that they would be within the actual 25 -ft. to 80 -ft. right-of-way.

Both walls of each backhoe trench were examined for evidence of any potential archaeological specimens, features, or significant indicators of formation events. However, only one wall of each exposure was systematically troweled for profiling. Troweling involved full cleaning of the entire exposure. One wall of each backhoe trench was profiled and drawn. Full soil descriptions were performed on selected profiles that included samples from the facility footprint, sewer line locations, and the proposed access road. Complete field soil observations included soil texture, consistence (wet and dry), presence and morphology of clay films, grain coatings, structure, abundance and size of roots, abundance and size of pores, presence of calcium carbonate, horizon boundaries, and Munsell colors (wet and dry). These attributes permit designation of the soil and sedimentary horizons in standard soil nomenclature (Birkeland 1984: 353-360; Soil Survey Staff 1993:117-135). Soils were also examined for the presence of potentially datable charcoal or other organics.

\section{Laboratory Methods}

The artifacts recovered during the survey were returned to the CAR laboratory. All artifacts recovered were identified and analyzed. Processing of recovered artifacts began with washing and sorting into appropriate categories (e.g., debitage, projectile points, bifaces, unifaces, etc.). Individual categories were analyzed by specific attributes designed for each group. All data was entered into Access and Excel spreadsheets, and copies of electronic and paper records will be submitted to the client upon request. All artifacts were returned to the land owner and all copies of projectrelated records are permanently curated at the Center for Archaeological Research.

\section{Results of Survey Investigations}

A total of 98 shovel tests was excavated within the 132-acre portion of the area proposed for acquisition outside of the Rio Grande floodplain (Figure 3-2). Of these, 43 (44\%) were positive. The 28 acres falling within the Rio Grande floodplain were subject to surface reconnaissance only. No sites were identified within the Rio Grande floodplain as a result of this reconnaissance. Four of the five previously

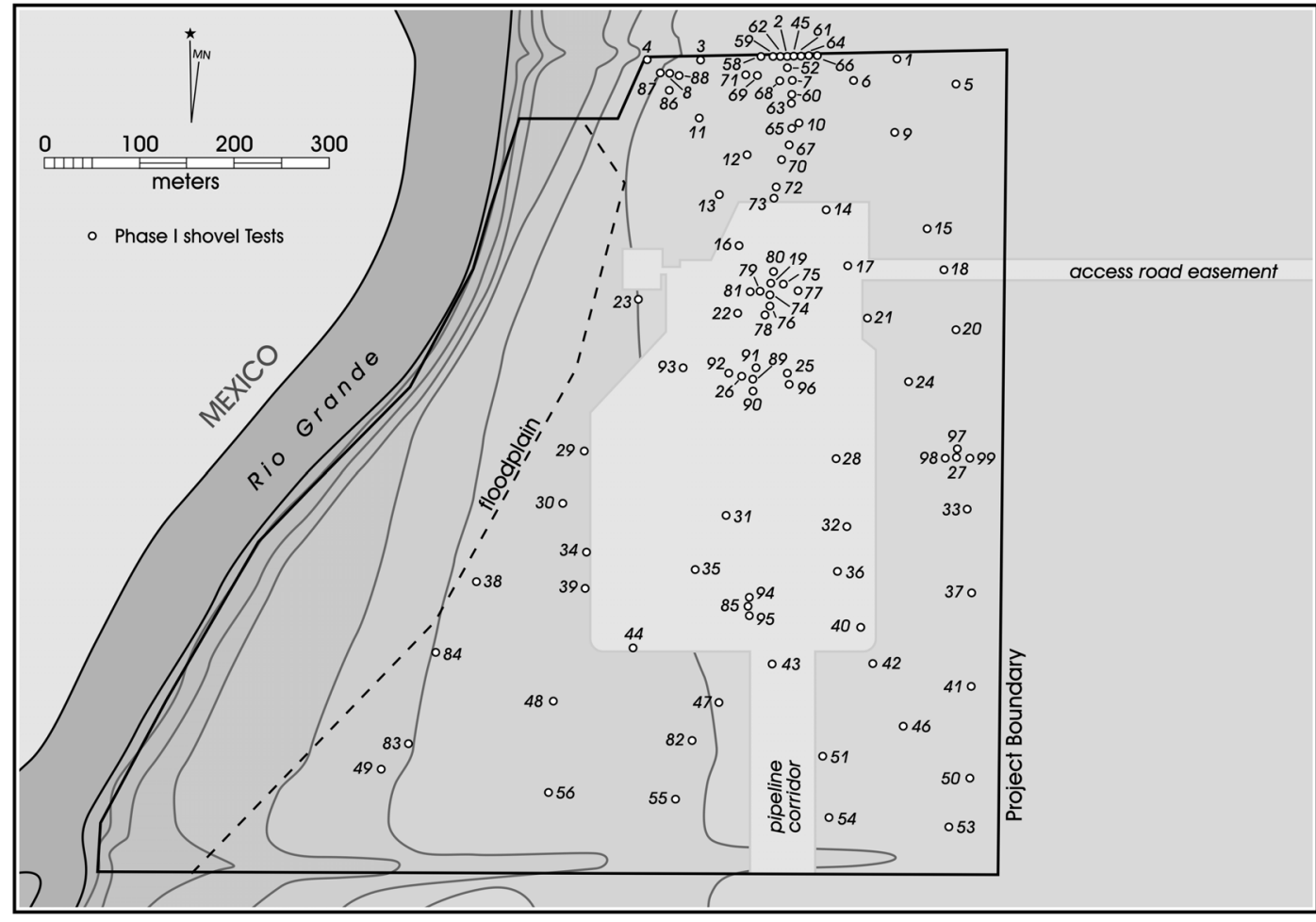

Figure 3-2. Project area with locations of shovel tests. 
identified sites were relocated during the survey and shovel testing of the 132-acre portion of the project area. No surface or subsurface indication of Provisional Site 5 could be identified during the CAR survey.

Thirty-five backhoe trenches were excavated during the geomorphological investigations of the project area. Of these, 20 were excavated in the proposed location of the detention facility, five in the water and sewer line corridor, and 10 in the proposed access road right-of-way (Figure 3-3).

Based on the survey, shovel testing, and backhoe trenching, 11 sites were defined (Field Sites 1-11). Field Sites 1-4 were identified through shovel testing while Field Sites 5-11 were identified through backhoe trenching. The sites identified during shovel testing are discussed in the following sections, while the sites identified through backhoe trenching are discussed under Results of Geoarchaeological Investigations.

\section{Field Site 1}

Field Site 1 is located in the north-central portion of the project area and combined MACTEC Provisional Sites 1 and 3 (Figure 3-4). Field Site 1 is $14,725 \mathrm{~m}^{2}$ in size and consists of a prehistoric component with modern contamination. A fence line defines the northern boundary of the site and a two-track dirt road runs east-west through the northern portion of the site. Surface and subsurface cultural material continues up to the fence line indicating that the site boundaries extend beyond the limits of the project area. At the time of survey, surface visibility in the site area was poor due to high grass cover that was predominant over the entire project area. A total of 22 shovel tests was excavated to determine the site boundary and depth of cultural materials. No backhoe trenches were excavated on this site. Sixteen $(73 \%)$ of the shovel tests were positive for cultural material. Cultural material was encountered to a maximum depth of $60 \mathrm{cmbs}$. An array of prehistoric and modern cultural material was recovered from the first three levels of the shovel tests with a mixture of lithic debitage, lithic tools, burned rock, charcoal, mussel shell fragments, glass and metal (Tables 3-1 and 3-2). The average number of lithic debitage per positive shovel test was 5.4, with peaks in Level $2(n=15)$ and Level $5(n=23)$. Modern glass occurred in Level 6 of Shovel Test (ST) 52 and could be indicative of some disturbance in the area by pipe trenches. No features or diagnostic artifacts were identified on the site and the age of the prehistoric component is unknown.

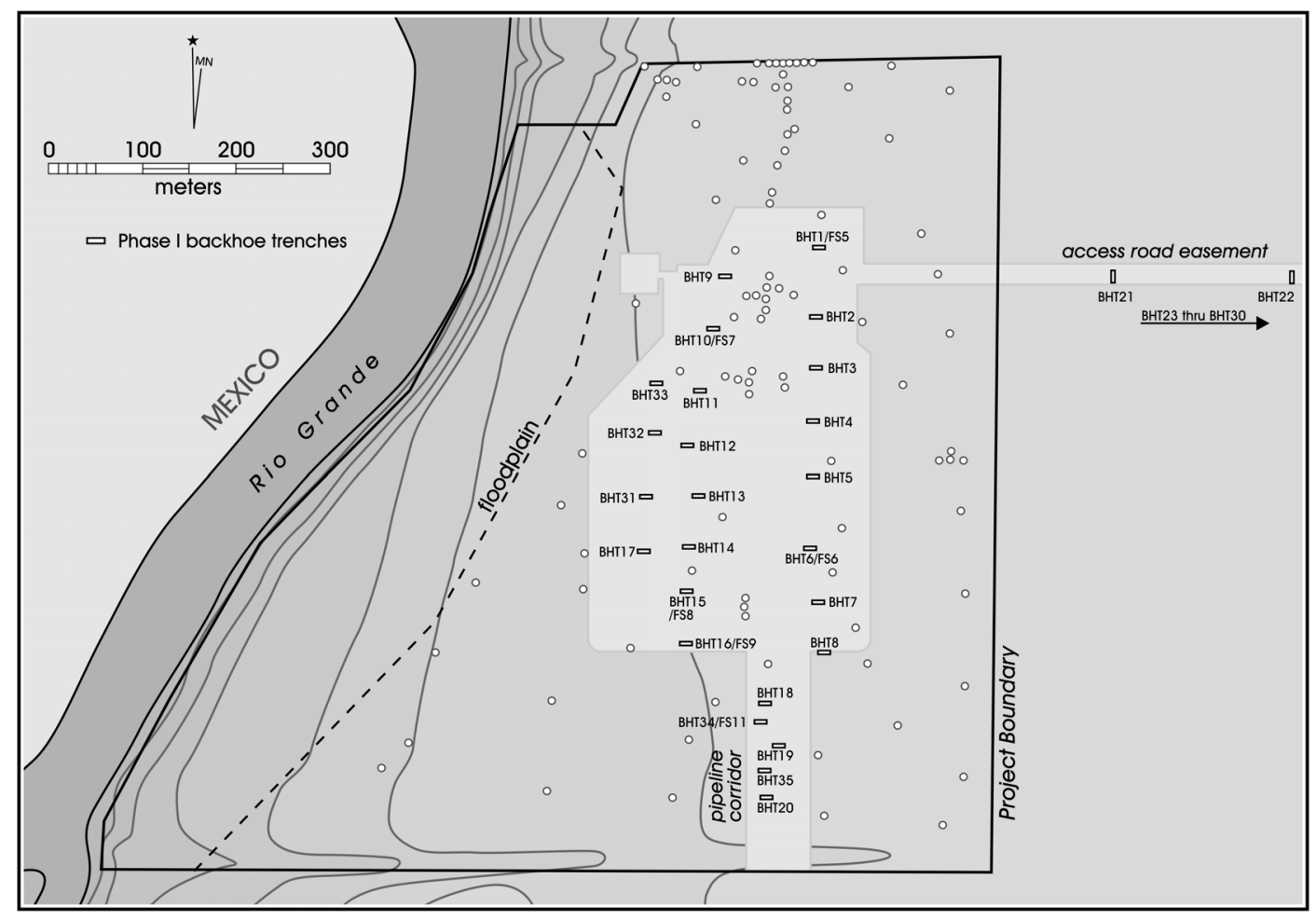

Figure 3-3. Project area with locations of backhoe trenches. 


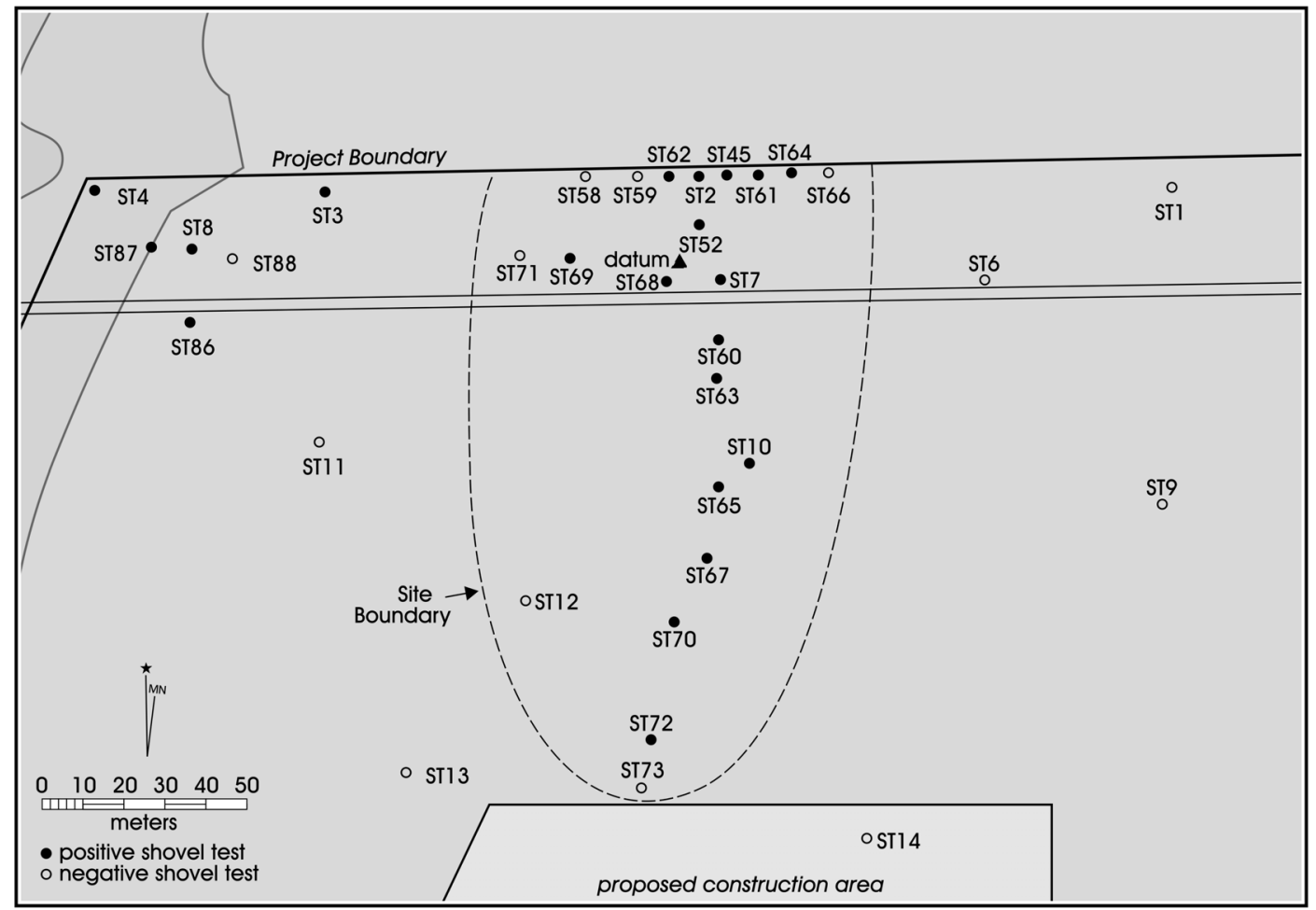

Figure 3-4. Map of Field Site 1 showing locations of shovel tests.

\section{Field Site 2}

Field Site 2 (the northern portion of MACTEC Provisional Site 4) is located in the central portion of the project area along a north-south orientated fence line. The fence line is the eastern boundary of the site (Figure 3-5). The site is approximately $1,947 \mathrm{~m}^{2}$ in size. Surface visibility on the site was poor, with exception of the area along the fence line where lithic debitage was evident. A total of 10 shovel tests was excavated to determine the boundaries of the site and the depth of cultural materials. Six (60\%) of the shovel tests were positive for cultural materials. Cultural material was encountered to a maximum depth of $60 \mathrm{cmbs}$. A very low density of artifacts $(n=19)$ was recovered from shovel tests; materials included lithic debitage (an average of 2.5 per positive shovel test), burned rock, mussel shell fragments, charcoal and lithic tools (Tables 3-3 and 3-4). Lithic debitage was encountered throughout Levels 1-6, while burned rock, charcoal, and mussel fragments were sparse. Lithic tools $(n=2)$ were recovered from Levels 2 and 4. No features were identified on the site. One diagnostic Caracara arrow point dating to the Late Prehistoric period was recovered from Level $4(30-40 \mathrm{cmbs})$ of ST 74.

\section{Field Site 3}

Field Site 3, MACTEC Provisional Site 2, is located along the northern boundary of the project area and is bound by fence lines to the north and west (Figure 3-6). This multicomponent site is $2,015 \mathrm{~m}^{2}$ in size with historic and prehistoric materials. A two-track dirt road, also associated with Field Site 1, runs along the southern portion of the site. Surface visibility was poor on the site, except along the twotrack road where glass and ceramics were observed. Six shovel tests were excavated on this site to determine the depth of cultural materials and to define site boundaries. No backhoe trenches were excavated on site. Five (83\%) of the shovel tests were positive for cultural material. Historic and prehistoric cultural material was encountered to a depth of $50 \mathrm{cmbs}$. Artifacts included glass, metal, ceramics, debitage, charcoal and mussel shell fragments (Tables 3-5 and 3-6). A modern brick structure is located approximately $40 \mathrm{~m}$ to the south of the site (Figure 3-7). The majority of the historic material (an average of 12.8 per positive shovel test) recovered from the shovel tests consisted of metal $(n=35)$ and glass $(n=27)$. One ceramic sherd each was encountered in Level 1 of ST 86 and Level 5 of ST 87. The 
Table 3-1. Artifacts and Ecofacts Recovered from Field Site 1, by Shovel Test

\begin{tabular}{|c|c|c|c|c|c|c|c|c|c|}
\hline Shovel Test & Level & Debitage & Lithic Tool/Core & Burned Rock & Charcoal & Mussel Shell & Glass & Metal & Total \\
\hline 2 & 3 & 4 & & & & & & & 4 \\
\hline 2 & 6 & 1 & & & & & & & $\overline{1}$ \\
\hline 7 & 2 & 5 & & & & & & & 5 \\
\hline 7 & 4 & 3 & & & & & & & 3 \\
\hline 7 & 5 & 11 & & & & & & & 11 \\
\hline 10 & 5 & & 1 & & & & & & 1 \\
\hline 45 & 1 & 1 & & & & & & & 1 \\
\hline 45 & 2 & 1 & & 1 & & 1 & & & 3 \\
\hline 45 & 6 & 1 & & & & & & & 1 \\
\hline 52 & 1 & 2 & & & & & & & 2 \\
\hline 52 & 2 & 1 & & & & & & & 1 \\
\hline 52 & 3 & 3 & & & & & & & 3 \\
\hline 52 & 4 & 3 & & & & & & & 3 \\
\hline 52 & 5 & 3 & & & & & & & 3 \\
\hline 52 & 6 & & & & & & 1 & & 1 \\
\hline 60 & 1 & & & & & & & 1 & 1 \\
\hline 60 & 2 & 1 & & & & & & & 1 \\
\hline 60 & 3 & 1 & & & & & & & 1 \\
\hline 60 & 6 & 1 & & & & & & & 1 \\
\hline 61 & 1 & 1 & & 1 & 1 & 1 & 2 & & 5 \\
\hline 61 & 2 & 3 & & & & 1 & 1 & & 5 \\
\hline 61 & 3 & 1 & & 1 & & & & & 2 \\
\hline 61 & 4 & 1 & & & 1 & & & & 1 \\
\hline 61 & 5 & 1 & & & & & & & 1 \\
\hline 61 & 6 & 1 & & & & & & & 1 \\
\hline 62 & 3 & 1 & & & & & & & 1 \\
\hline 63 & 1 & 3 & & & & & & & 1 \\
\hline 63 & 2 & 1 & & & & & & & 3 \\
\hline 63 & 4 & 2 & & & & & & & 2 \\
\hline 63 & 6 & 3 & & & & & & & 3 \\
\hline 64 & 4 & 3 & & & & & & & 3 \\
\hline 65 & 2 & 1 & & & & & & & 1 \\
\hline 65 & 3 & 1 & & & & & & & 1 \\
\hline 65 & 5 & 1 & & & & & & & 1 \\
\hline 67 & 2 & 1 & & & & & & & 1 \\
\hline 68 & 4 & 4 & & & & & & & 4 \\
\hline 68 & 5 & 5 & & & & & & & 5 \\
\hline 69 & 2 & 1 & & & & & & & 1 \\
\hline 70 & 1 & 3 & & & & & & & 3 \\
\hline 70 & 3 & 1 & & & & & & & 1 \\
\hline 70 & 5 & 1 & & & & & & & 1 \\
\hline 72 & 1 & 1 & & & & & & & 1 \\
\hline 72 & 5 & 1 & & & & & & & 1 \\
\hline 72 & 6 & 3 & & 1 & & & & & 4 \\
\hline \multicolumn{2}{|l|}{ Total } & 87 & 1 & 4 & & 3 & 4 & 1 & 100 \\
\hline
\end{tabular}

* Charcoal count stands for presence; not included in total count. 
Table 3-2. Artifacts and Ecofacts Recovered from Shovel Tests at Field Site 1, by Level

\begin{tabular}{|c|c|c|c|c|c|c|c|c|}
\hline Level & Debitage & Lithic Tool/Core & Burned Rock & Charcoal & Mussel Shell & Glass & Metal & Total \\
\hline 1 & 11 & & 1 & 1 & 1 & 2 & 1 & 16 \\
\hline 2 & 15 & & 1 & & 2 & 1 & & 19 \\
\hline 3 & 12 & & 1 & & & & & 13 \\
\hline 4 & 16 & & & 1 & & & & 16 \\
\hline 5 & 23 & 1 & & & & & & 24 \\
\hline 6 & 10 & & 1 & & & 1 & & 12 \\
\hline Total & 87 & 1 & 4 & & 3 & 4 & 1 & 100 \\
\hline
\end{tabular}

* Charcoal count stands for presence; not included in total count.

historic component dates to the late nineteenth and early twentieth centuries (1880s-1920s), based on the ceramics recovered from the previous MACTEC investigation (Appendix B). A single piece of lithic debitage was recovered from Level 2 of ST 86, located south of the two-track road, although numerous other pieces of debitage were noted by Robert Perry on the site's surface during the previous MACTEC investigation (Appendix A). No features were identified on the site.

\section{Field Site 4}

Field Site 4 (the southern portion of MACTEC Provisional Site 4) is a prehistoric site located south of Field Site 2, in the north-central portion of the project area (Figure 3-8). While originally this area was part of Provisional Site 4, shovel test excavations performed between the two sites were negative, essentially splitting MACTEC Provisional Site 4

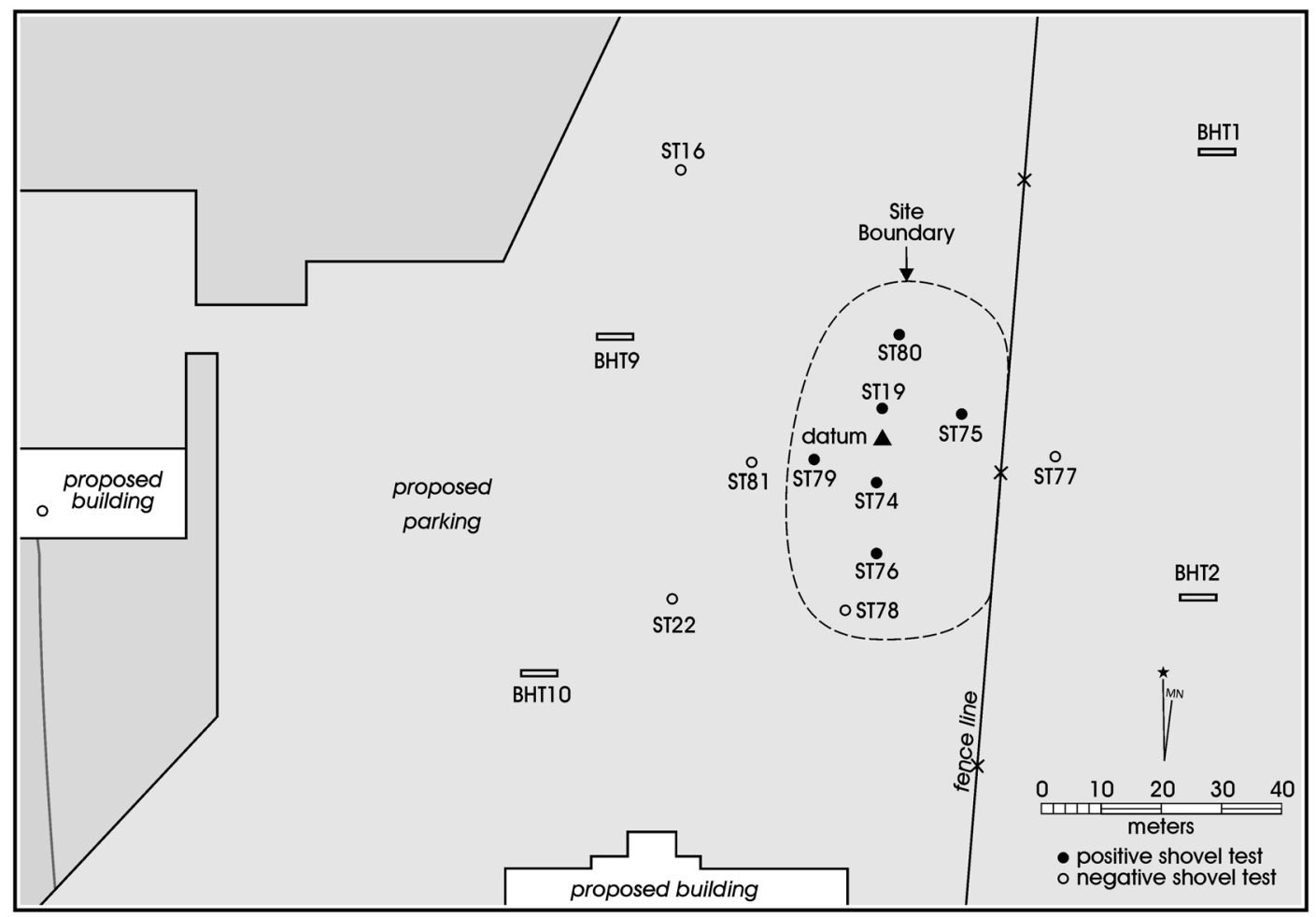

Figure 3-5. Map of Field Site 2, showing locations of shovel tests. 
Table 3-3. Artifacts and Ecofacts Recovered from Field Site 2, by Shovel Test

\begin{tabular}{|c|c|c|c|c|c|c|c|}
\hline Shovel Test & Level & Debitage & Lithic Tools/Cores & Burned Rock & Charcoal & Mussel Shell & Total \\
\hline 19 & 1 & 1 & & & & & 1 \\
\hline 19 & 2 & & & & 1 & & 0 \\
\hline 19 & 3 & 1 & & & & & 1 \\
\hline 19 & 4 & 1 & & & & 1 & 2 \\
\hline 19 & 5 & & & & 1 & & 0 \\
\hline 19 & 6 & 1 & & & 1 & & 1 \\
\hline 74 & 1 & 1 & & & & & 1 \\
\hline 74 & 2 & 1 & & & & & 1 \\
\hline 74 & 4 & & 1 & & & & 1 \\
\hline 75 & 1 & 1 & & & & & 1 \\
\hline 75 & 4 & 2 & & & & & 2 \\
\hline 75 & 3 & 2 & & & & & 2 \\
\hline 76 & 2 & 1 & 1 & & & & 2 \\
\hline 79 & 1 & & & 1 & & & 1 \\
\hline 79 & 3 & 1 & & & & & 1 \\
\hline 79 & 4 & 1 & & & & & 1 \\
\hline 80 & 5 & 1 & & & & & 1 \\
\hline \multicolumn{2}{|l|}{ Total } & 15 & 2 & 1 & & 1 & 19 \\
\hline
\end{tabular}

* Charcoal count stands for presence, not included in total count.

Table 3-4. Artifacts and Ecofacts Recovered from Shovel Tests at Field Site 2, by Level

\begin{tabular}{|c|c|c|c|c|c|c|}
\hline Level & Debitage & Lithic Tools/Cores & Burned Rock & Charcoal & Mussel Shell & Total \\
\hline 1 & 3 & & 1 & & & 4 \\
\hline 2 & 2 & 1 & & 1 & & 3 \\
\hline 3 & 4 & & & & & 4 \\
\hline 4 & 4 & 1 & & 1 & 1 & 6 \\
\hline 5 & 1 & & & & & 1 \\
\hline 6 & 1 & & & 1 & & 1 \\
\hline Total & 15 & 2 & 1 & & 1 & 19 \\
\hline
\end{tabular}

* Charcoal count stands for presence; not included in total count.

in half. Field Site 4 measures $3,120 \mathrm{~m}^{2}$ in size. Visibility was poor except for a few clear areas toward the western margin of the site and along the fence line where two to three bifaces and pieces of lithic debitage were noted. Eight shovel tests were excavated in the area to define site boundaries; four of the tests were positive for cultural materials. Artifacts were encountered to a depth of $50 \mathrm{cmbs}$. Cultural material recovered consisted of debitage (an average of 3.3 per positive shovel test; $n=13$ ) and a mussel shell fragment (Tables 3-7 and 3-8). Backhoe trenches were excavated to the east, north, and southwest of Field Site 4. No cultural materials were noted in the walls of the trenches or in the backdirt. No features were identified on the site and the age of the component cannot be determined, given the lack of prehistoric temporal diagnostics.

\section{Isolated Finds}

There were 11 shovel tests (STs 1, 5, 13, 16, 27, 35, 36, 41, 47,54 , and 85 ) that were located in non-site areas and yielded isolated artifacts (Table 3-9). Additional shovel tests that were negative for cultural materials were excavated in the vicinity of STs 27 and 85 . The remaining shovel tests could not be relocated because the flags marking their locations had been removed. 


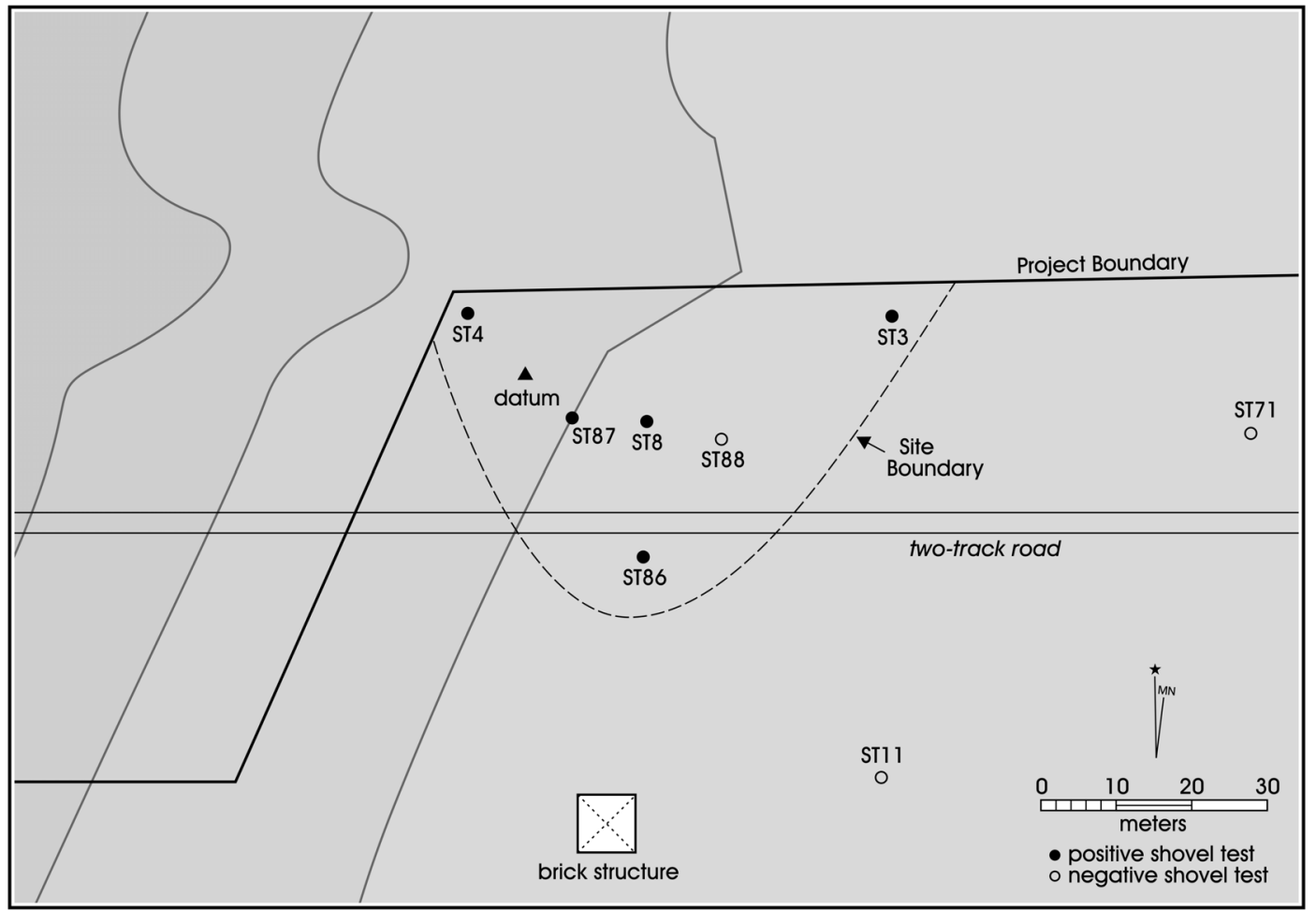

Figure 3-6. Map of Field Site 3 showing locations of shovel tests.

Table 3-5. Artifacts and Ecofacts Recovered from Field Site 3, by Shovel Test

\begin{tabular}{|c|c|c|c|c|c|c|c|c|}
\hline Shovel Test & Level & Debitage & Charcoal & Mussel Shell & Metal & Glass & Ceramic & Total \\
\hline 3 & 1 & & & 1 & 1 & 4 & & 6 \\
\hline 3 & 2 & & & & & 1 & & 1 \\
\hline 3 & 3 & & & & 1 & & & 1 \\
\hline 3 & 4 & & 1 & & & 1 & & 1 \\
\hline 3 & 5 & & & & & 1 & & 1 \\
\hline 4 & 2 & & & & 1 & 1 & & 2 \\
\hline 4 & 3 & & & & 1 & 11 & & 12 \\
\hline 4 & 4 & & & & & 4 & & 4 \\
\hline 8 & 2 & & & & & 1 & & 1 \\
\hline 8 & 3 & & & 1 & & & & 1 \\
\hline 8 & 5 & & & 1 & & & & 1 \\
\hline 86 & 1 & & & & & 1 & 1 & 2 \\
\hline 86 & 2 & 1 & & & & & & 1 \\
\hline 87 & 1 & & & & 5 & 1 & & 6 \\
\hline 87 & 2 & & & & 2 & & & 2 \\
\hline 87 & 3 & & & & 8 & 1 & & 9 \\
\hline 87 & 4 & & & & 15 & & & 15 \\
\hline 87 & 5 & & & & 1 & & 1 & 2 \\
\hline Total & & 1 & & 3 & 35 & 27 & 2 & 68 \\
\hline
\end{tabular}

* Charcoal count stands for presence; not included in total count. 
Table 3-6. Artifacts and Ecofacts Recovered from Shovel Tests at Field Site 3, by Level

\begin{tabular}{|c|c|c|c|c|c|c|c|}
\hline Level & Debitage & Charcoal & Mussel Shell & Metal & Glass & Ceramic & Total \\
\hline 1 & & & 1 & 6 & 6 & 1 & 14 \\
\hline 2 & 1 & & & 3 & 3 & & 7 \\
\hline 3 & & & 1 & 10 & 12 & & 23 \\
\hline 4 & & 1 & & 15 & 5 & & 20 \\
\hline 5 & & & 1 & 1 & 1 & 1 & 4 \\
\hline Total & 1 & & 3 & 35 & 27 & 2 & 68 \\
\hline
\end{tabular}

* Charcoal count stands for presence; not included in total count.

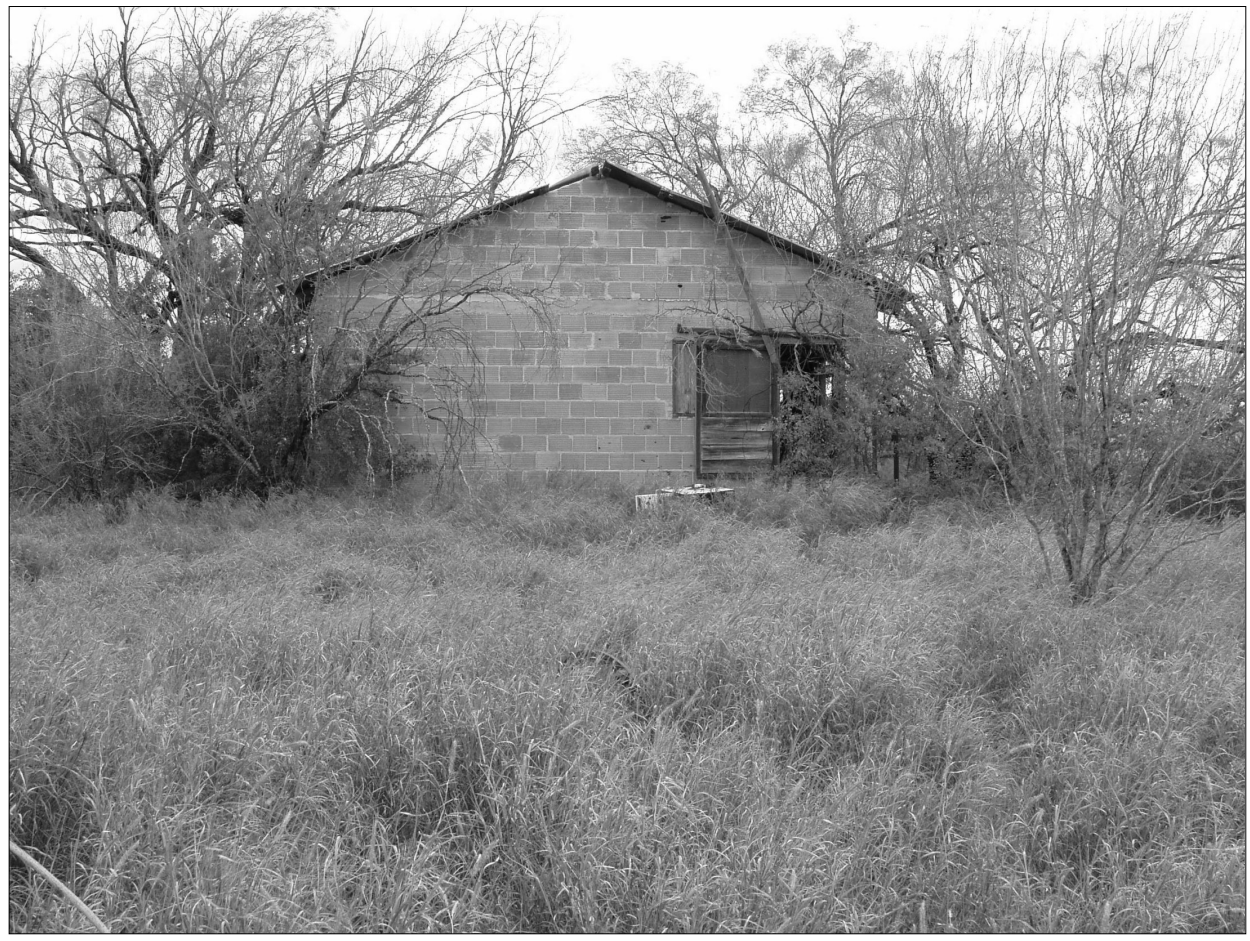

Figure 3-7. Brick structure located south of Field Site 3.

\section{Results of Geoarchaeological Investigations}

The proposed facility location is situated on the $T_{8}-T_{10}$ floodplains and the proposed access road ascends to older terraces terminating at the eastern margin of $\mathrm{T}_{12}$. The majority of the investigations focused on the proposed detention facility footprint area within the $\mathrm{T}_{8}-\mathrm{T}_{10}$ surfaces. In addition to shovel testing efforts within the project area, backhoe trenching was employed to examine the potential for buried archaeological deposits and better understand landscape and archaeological site formation. A total of 20 backhoe trenches was excavated within the proposed location of the detention facility, five trenches were placed within the indicated 200$\mathrm{ft}$. corridor where water and sewer lines are to be placed, and 10 trenches were excavated along the proposed access road on the eastern side of the facility (see Figure 3-3). Nine backhoe trenches contained artifacts and ecofacts. The artifacts and ecofacts recovered from backhoe trenches are presented in Table 3-10. Profile descriptions for selected backhoe trenches are presented in Appendix C. 


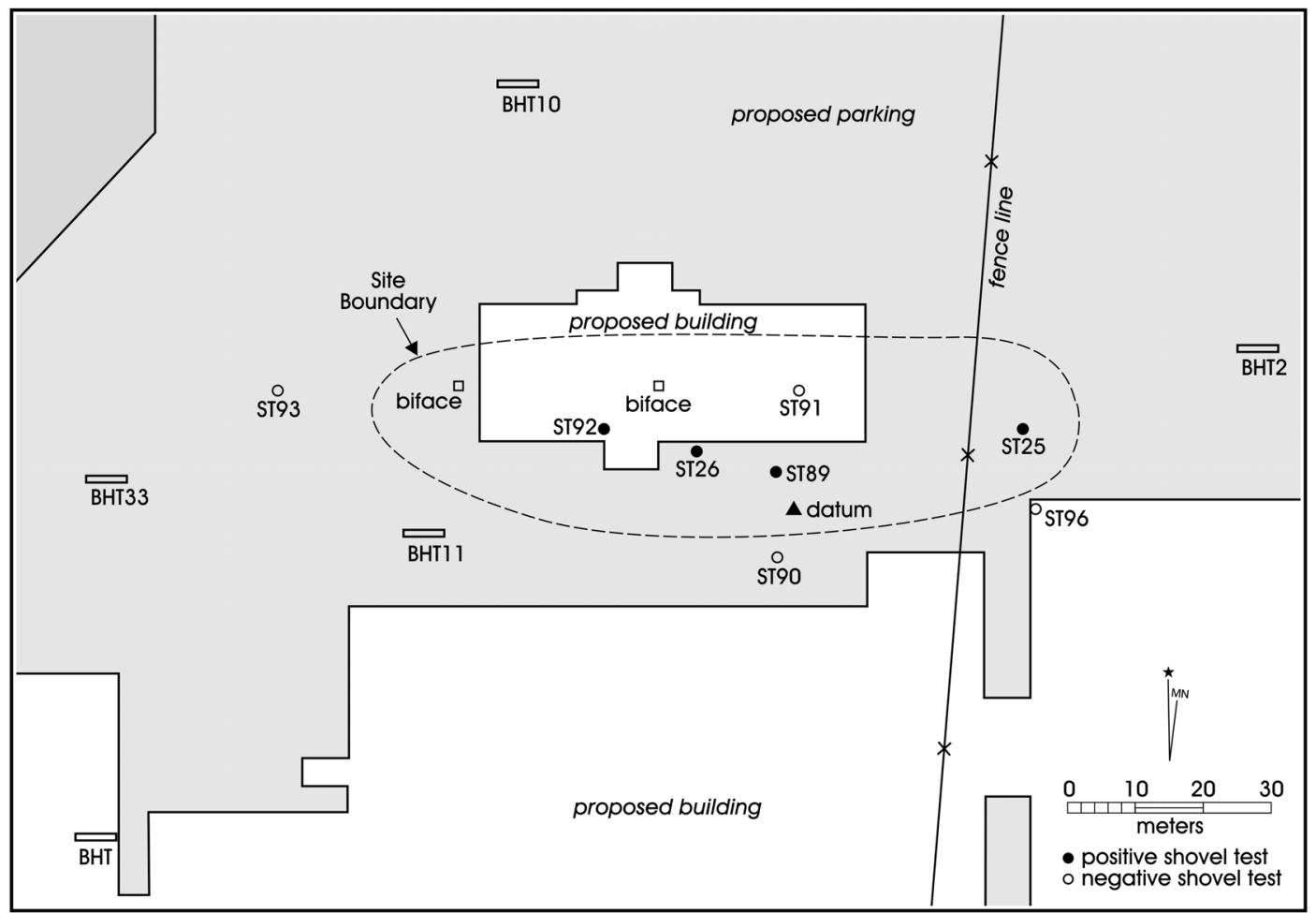

Figure 3-8. Map of Field Site 4 showing locations of shovel tests.

Table 3-7. Artifacts and Ecofacts Recovered from Field Site 4, by Shovel Test

\begin{tabular}{|c|c|c|c|c|}
\hline Shovel Test & Level & Debitage & Mussel Shell & Total \\
\hline 25 & 1 & 1 & & 1 \\
\hline 25 & 3 & 1 & & 1 \\
\hline 25 & 4 & 1 & & 1 \\
\hline 26 & 1 & 1 & & 1 \\
\hline 89 & 5 & 1 & & 1 \\
\hline 92 & 2 & 1 & & 1 \\
\hline 92 & 4 & 6 & 1 & 7 \\
\hline 92 & 5 & 1 & & 1 \\
\hline \multicolumn{2}{|c|}{ Total } & 13 & 1 & 14 \\
\hline
\end{tabular}

Table 3-8. Artifacts and Ecofacts Recovered from Shovel Tests at Field Site 4, by Level

\begin{tabular}{|c|c|c|c|}
\hline Level & Debitage & Mussel Shell & Total \\
\hline 1 & 2 & & 2 \\
\hline 2 & 1 & & 1 \\
\hline 3 & 1 & & 1 \\
\hline 4 & 7 & 1 & 8 \\
\hline 5 & 2 & & 2 \\
\hline Total & 13 & 1 & 14 \\
\hline
\end{tabular}


Table 3-9. Isolated Finds

\begin{tabular}{|c|c|c|c|}
\hline Shovel Test & Level & Artifact & Count \\
\hline 1 & 3 & Debitage & 1 \\
\hline 5 & 1 & Debitage & 1 \\
\hline 5 & 2 & Debitage & 1 \\
\hline 13 & 3 & Debitage & 1 \\
\hline 16 & 1 & Debitage & 2 \\
\hline 27 & 1 & Debitage & 1 \\
\hline 27 & 3 & Debitage & 1 \\
\hline 35 & 1 & Debitage & 1 \\
\hline 35 & 1 & Lithic tools and cores & 1 \\
\hline 36 & 1 & Debitage & 1 \\
\hline 41 & 1 & Debitage & 1 \\
\hline 47 & 3 & Debitage & 1 \\
\hline 54 & 3 & Debitage & 1 \\
\hline 85 & 3 & Debitage & 3 \\
\hline & & & 17 \\
\hline
\end{tabular}

Table 3-10. Artifacts and Ecofacts Recovered from Backhoe Trenches

\begin{tabular}{|c|c|c|}
\hline Backhoe Trench & Artifact/Ecofact & Count/Weight (g) \\
\hline 1 & Debitage & 1 \\
\hline 6 & Bone & 29.61 \\
\hline 9 & Mussel shell & 73.86 \\
\hline 10 & Debitage & 1 \\
\hline 10 & Lithic tools and/or cores & 1 \\
\hline 15 & Debitage & 1 \\
\hline 15 & Debitage & 1 \\
\hline 16 & Debitage & 1 \\
\hline 16 & Debitage & 1 \\
\hline 20 & Mussel shell & 4.13 \\
\hline 26 & Lithic tools and/or cores & 1 \\
\hline 34 & Debitage & 1 \\
\hline
\end{tabular}

\section{Backhoe Trenches within the Proposed Facility Footprint}

Twenty backhoe trenches (BHTs 1-17 and 31-33) were placed within the proposed area of the detention facility footprint. All of these trenches contained primarily lowenergy sediments and soil profiles characterized by recent plow zone soils (Ap) unconformably overlying $\mathrm{B}$ and $\mathrm{Bw}$ soils. Two plow zones were visible in several trenches indicating a previous deeper plow zone $(\sim 50 \mathrm{cmbs})$ and a more recent shallow depth of plowing $(\sim 35-40 \mathrm{cmbs})$. C horizons conformably underlie the $\mathrm{B}$ horizons and are mostly
$\mathrm{Ck}$ or $\mathrm{Cn}$ soils with fine filaments and soft masses of $\mathrm{CaCO}_{3}$ or other unidentified salts. Almost all of the $\mathrm{C}$ horizons are fine silt loams. Small gravel clasts were present in only three of the trenches (BHTs 12, 17, and 31) within this portion of the project area. Only BHT 17 (Figure 3-9) contained a dense clast-supported $2 \mathrm{C}$ horizon indicative of a higher-energy deposit. The fine sediment texture and context of all trenches indicates that the $\mathrm{T}_{8}-\mathrm{T}_{10}$ floodplains where the proposed facility will be situated all represent low-energy floodplain deposits. The potential for intact archaeological deposits in this setting is high.

Buried artifacts were identified in five trenches (BHTs 1, 6, 10,15 , and 16) within this area. BHT 1 contained a single flake at the top of the $\mathrm{C} 1$ horizon at a depth of $63 \mathrm{cmbs}$. This locality was defined as Field Site 5 (Table 3-11). A small amount of bone $(29.61 \mathrm{~g})$ was recovered from the backdirt during excavation of BHT 6 . The bone was not observed in situ and was recovered exclusively from backdirt removed by the backhoe. The approximate provenience for the bone is $0-2 \mathrm{~m}$ west of the eastern end of BHT 6 and approximately $80-100 \mathrm{~cm}$ below the ground surface. Careful inspection of both walls failed to identify any bone still in place within the trench. Twenty-one bone fragments were recovered. The bone is chemically weathered. It exhibits previous dry bone fractures and had been broken from the backhoe excavation of this trench. The largest piece (69 $\mathrm{mm}$ ) is a portion of the right proximal diaphysis of a human ulna. None of the other pieces are currently identified as human; however, the sizes are consistent with human bones. Three pieces appear to be articular processes of vertebrae, five are unspecified long bone shaft fragments, and the remaining 12 are unidentifiable small fragments (less than $11 \mathrm{~mm}$ ). This bone was not recognized as human at the time of the fieldwork. No evidence of a burial pit was observed within BHT 6. The lack of other bone, the lack of evidence of a burial pit, and the older breaks on this bone suggest that it has been previously disturbed. This locality was defined as Field Site 6 (Table 3-11).

An early stage biface was recovered from BHT 10 in the middle of the Ck2 horizon at $146 \mathrm{cmbs}$ (Figure 3-10). A flake also was present at the top of the $\mathrm{Ck} 2$ sediment at a depth of $120 \mathrm{cmbs}$. This locality is defined as Field Site 7 (Table 3-11). Two adjacent flakes were collected from the top of the Ck2 horizon of BHT 15 at a depth of $155 \mathrm{cmbs}$ (Figure 3-11). This locality is defined as Field Site 8 (Table 3-11). A single artifact was found near the soil surface associated with the base of the plow zone in BHT 16. This 


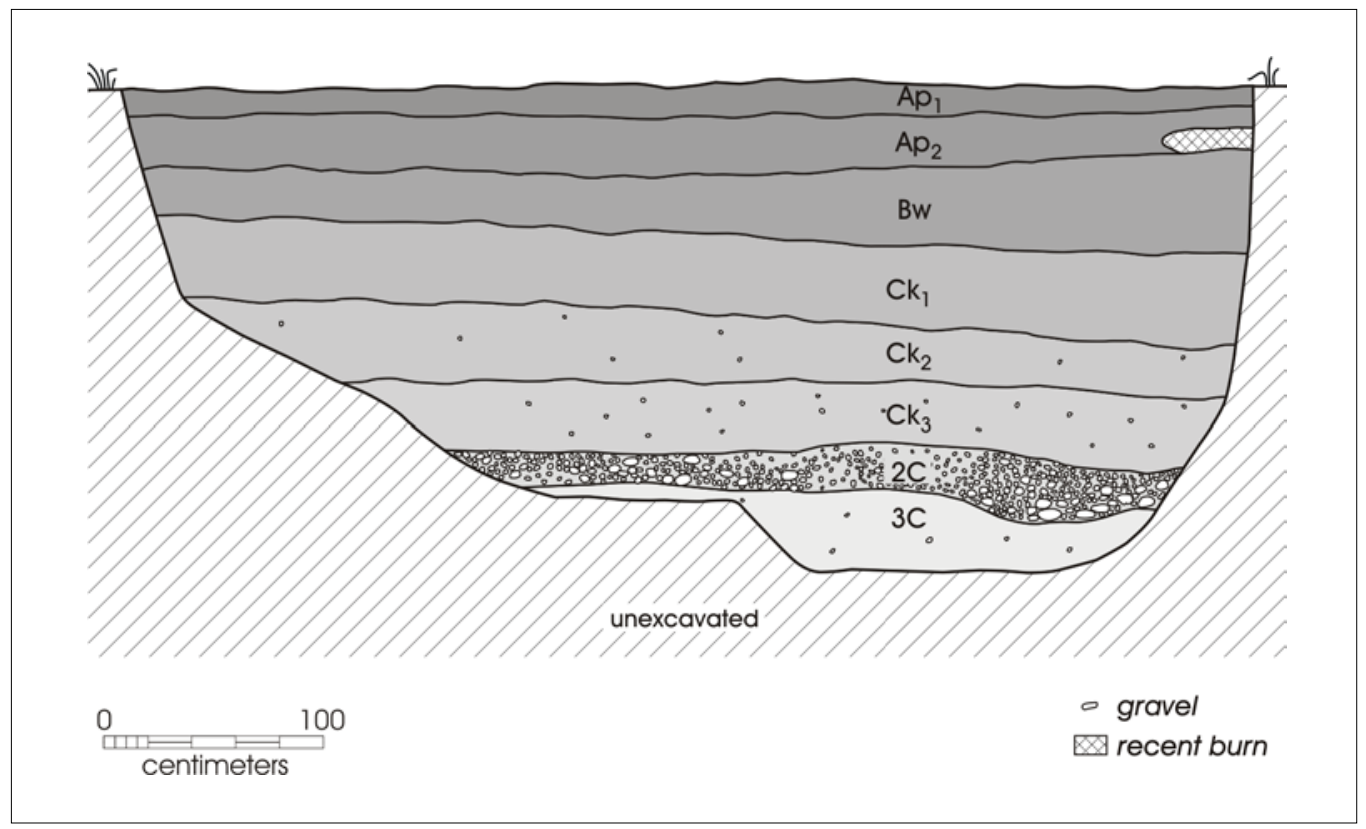

Figure 3-9. South wall profile of Backhoe Trench 17.

flake was at approximately $48 \mathrm{cmbs}$. One additional flake was recovered at the top of the Ck2 horizon at a depth of $134 \mathrm{cmbs}$ within this trench. This locality is defined as Field Site 9 (Table 3-11).

A few additional materials may or may not be indicative of the presence of non-lithic archaeological artifacts; however, the cultural or natural association of these could not be unambiguously evaluated from the backhoe trenches. Two mussel shells (73.86 g) were recovered from the middle of the $\mathrm{Ck} 2$ horizon in BHT 9 (Figure 3-12) at depths of 83-91 cmbs. No other artifacts or clasts were associated with these shells. A relatively large amount of sandstone was present in the top of the Ck2 deposit of BHT 14 (Figure 3-13). Two pieces of sandstone, ranging from $10-17 \mathrm{~cm}$ in maximum dimension, were collected. Additional, much smaller (less than $4 \mathrm{~cm}$ ) pieces of rubified sandstone were present in the same sediment. The reddening of this sandstone could be due to chemical weathering. No charcoal or unambiguous evidence of thermal modification was apparent in this rock. The presence of these large clasts was not associated with evidence of localized, high-energy alluvial deposits.

Table 3-11. Correspondence of Field Sites with Backhoe Trenches and Artifact Recovery Data

\begin{tabular}{|l|c|l|c|}
\hline Field Site & Backhoe Trench & \multicolumn{1}{|c|}{ Artifact Type } & Depth Below Surface \\
\hline Field Site 5 & BHT 1 & 1 flake & $63 \mathrm{cmbs}$ \\
\hline Field Site 6 & BHT 6 & $\begin{array}{l}21 \text { bone fragments (1 is a human } \\
\text { proximal ulna) }\end{array}$ & approx. 80-100 cmbs \\
\hline Field Site 7 & BHT 10 & 1 flake & $120 \mathrm{cmbs}$ \\
\cline { 2 - 4 } & & 1 early stage biface & $146 \mathrm{cmbs}$ \\
\hline Field Site 8 & BHT 15 & 2 flakes & $155 \mathrm{cmbs}$ \\
\hline Field Site 9 & BHT 16 & 1 flake & $48 \mathrm{cmbs}$ \\
\cline { 2 - 4 } & & 1 flake & $134 \mathrm{cmbs}$ \\
\hline Field Site 10 & BHT 26 & 1 early stage biface & $75 \mathrm{cmbs}$ \\
\hline Field Site 11 & BHT 34 & 1 flake & $113 \mathrm{cmbs}$ \\
\hline
\end{tabular}




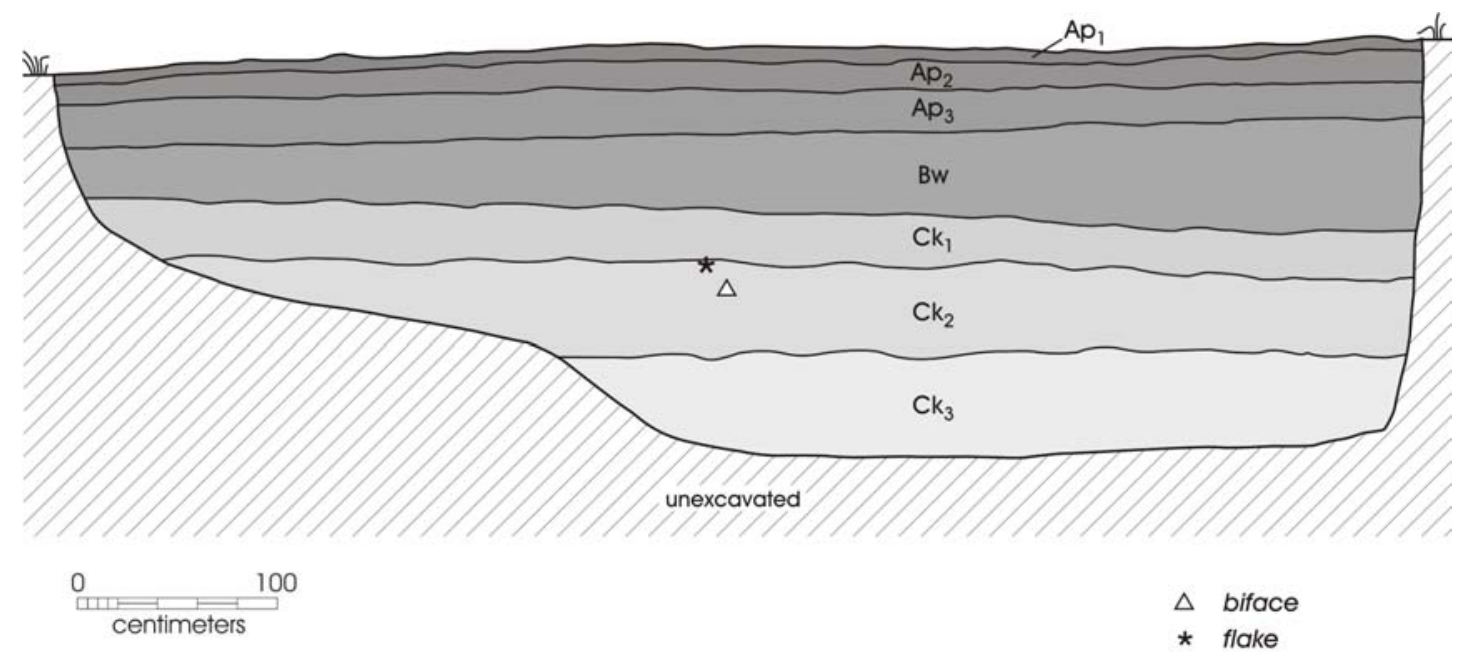

Figure 3-10. North wall profile of Backhoe Trench 10, Field Site 7.

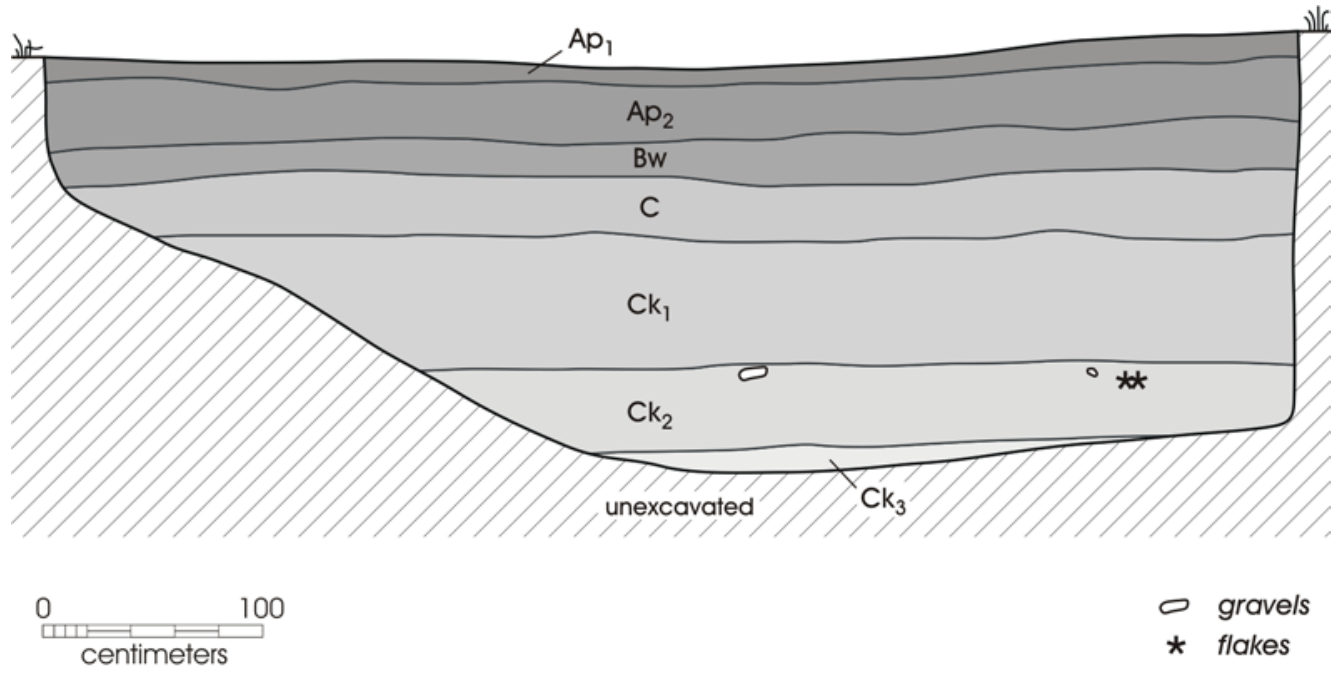

Figure 3-11. North wall profile of Backhoe Trench 15, Field Site 8. 


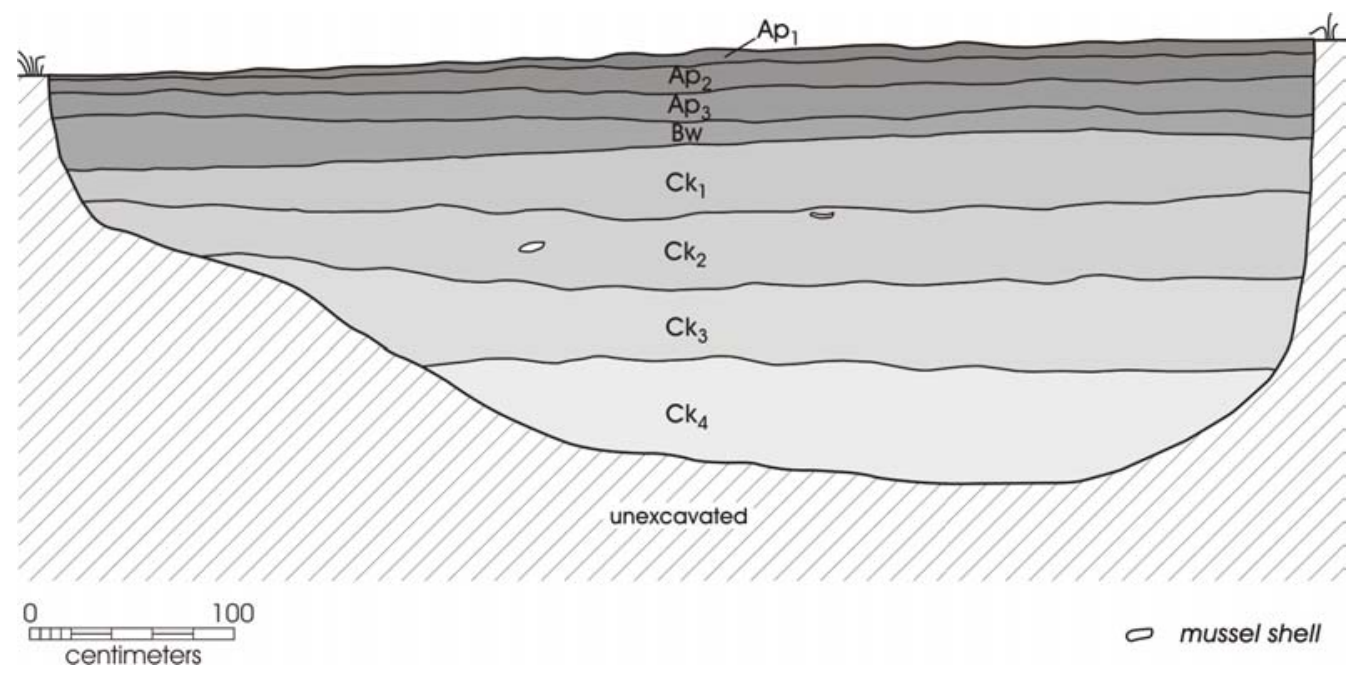

Figure 3-12. North wall profile of Backhoe Trench 9.

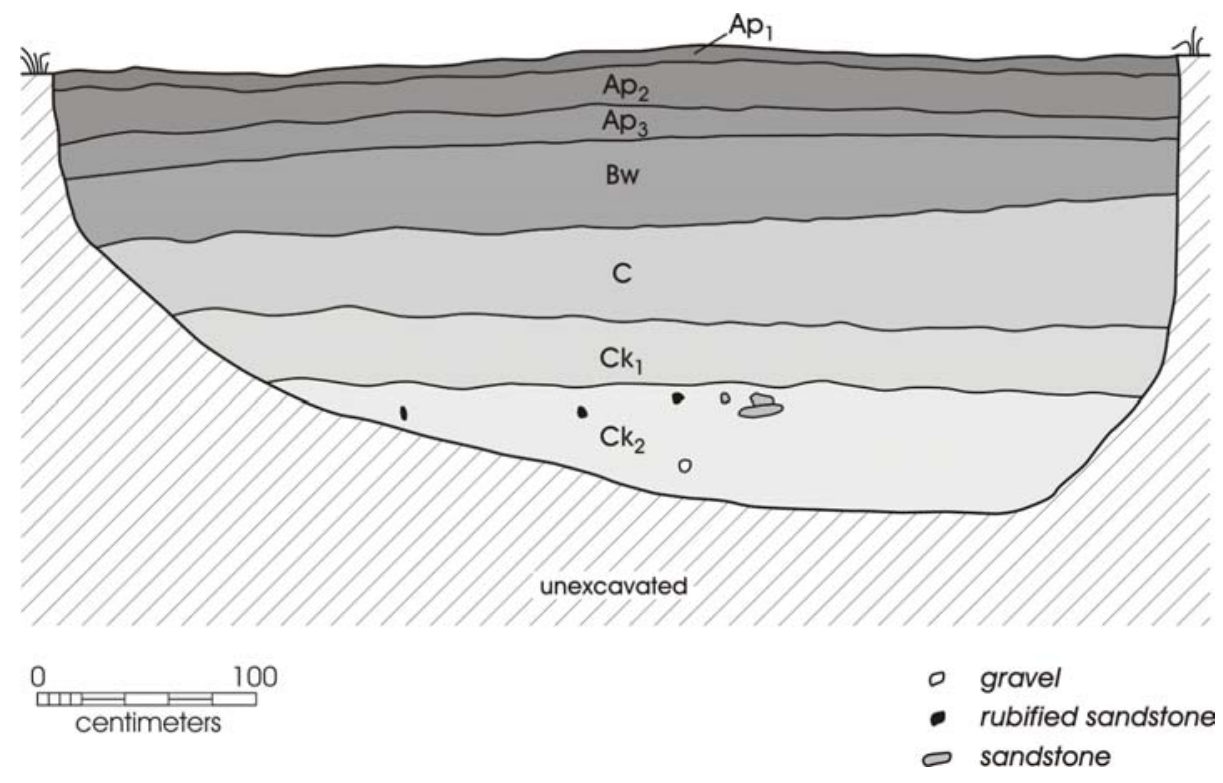

Figure 3-13. North wall profile of Backhoe Trench 14. 


\section{Backhoe Trenches within the Proposed Access Road}

Ten backhoe trenches (BHTs 21-30) were excavated along the proposed route of the access road to the detention facility. This testing of the roadway extended from the $T_{10}$ to the $T_{12}$ floodplain surfaces. The easternmost trench (BHT 30) was placed adjacent a much older abandoned high terrace that contained more abundant gravels than were evident in the settings where subsurface trenching was performed. The uppermost $\mathrm{A}$ horizon and underlying thin $\mathrm{C}$ sediment contained abundant gravels colluvially derived from this older terrace. There also were some gravels present in the lowermost horizons of BHT 30. Soils and sediments at the western end of the proposed roadway were identical to those examined within the facility footprint. Higher-energy gravels were present in the $2 \mathrm{C}$ and $4 \mathrm{C}$ sediments of BHT 23. There also were less dense gravels in the lowermost deposits of BHT 25 , but that trench contained extensive and deep disturbance that appears to be from excavation of an irrigation canal (Figure 3-14). Such irrigation ditches are apparent across several portions of the project area. A small number of redeposited limestone clasts were present in the upper Bt1 soil of BHT 29, just below the plow zone. Calcium carbonate on the upper sides of these clasts indicate that they had been moved from the context where the carbonate would have formed only on the underside when they were in situ. Evidence of older, more-developed soils than those in the proposed facility location was apparent in BHTs 22-30. The greater development on the eastern portion of the $T_{10}$ surface is probably due to time-transgressive effects of floodplain development. Only BHT 26 contained buried archaeological material in this corridor sample of the proposed roadway. One early stage biface was recovered from the middle of the Bt horizon at a depth of $75 \mathrm{cmbs}$ in BHT 26 (Figure 3-15). This same trench contained several small rubified pieces of sandstone at the base of the Bt horizon from 89-93 cmbs. There was no evidence of charcoal or any archaeological feature and it is uncertain whether the rubification was from chemical weathering or thermal alteration. A single piece of gravel also was present in the base of the Bt, but the sandstone clasts were not associated with any clear evidence of highenergy alluvial deposition. This locality is defined as Field Site 10 (Table 3-11).

\section{Backhoe Trenches within the Proposed Water and Sewer Line Corridor}

Five backhoe trenches (BHTs 18-20 and 34-35) were placed within the identified 200-ft.-wide corridor for water and sewer lines south of the detention facility. These trenches were located on the $\mathrm{T}_{9}$ floodplain surface. Sediments and soils observed in these trenches were analogous to those described for the main detention facility area. Small gravel clasts were present in the lowermost $\mathrm{C} 3$ and $2 \mathrm{C}$ horizons of BHTs 19 and 20. Buried archaeological material was present

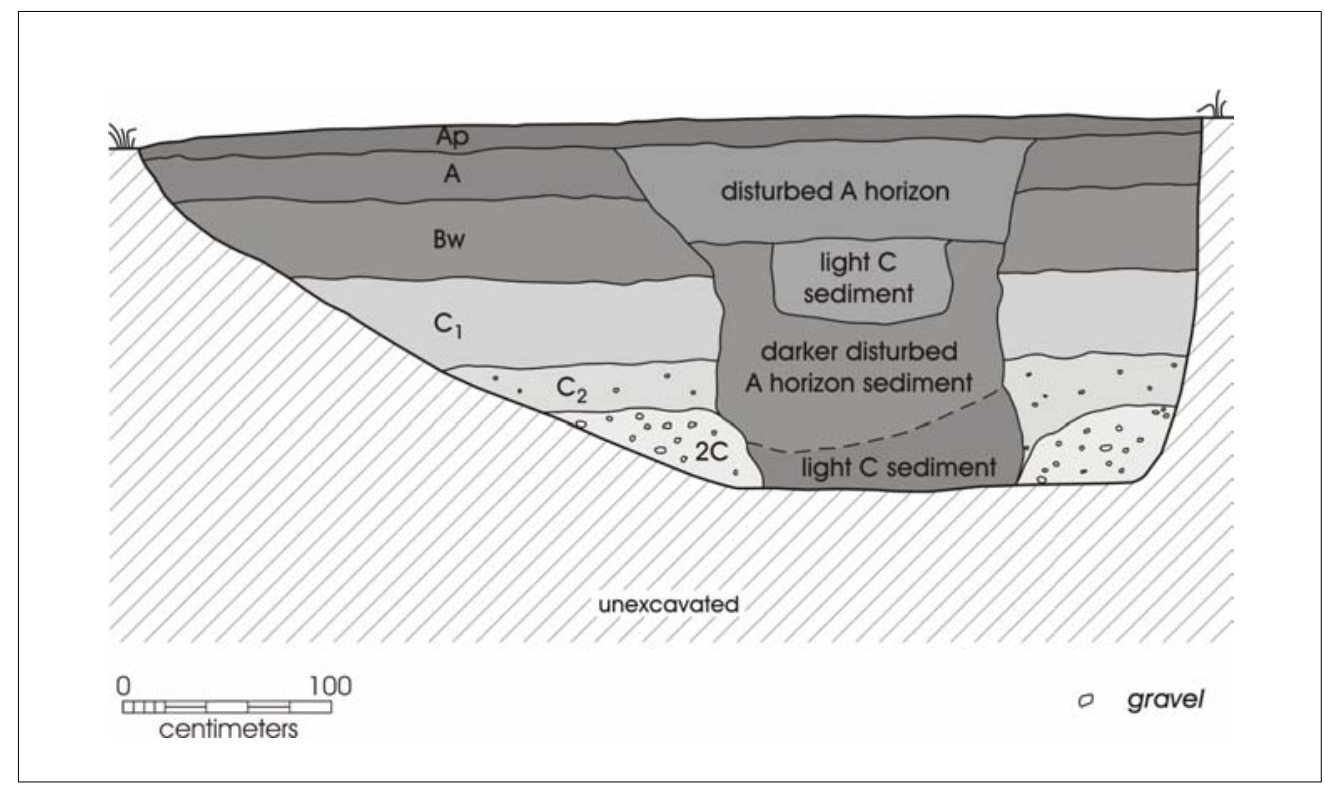

Figure 3-14. East wall profile of Backhoe Trench 25. 


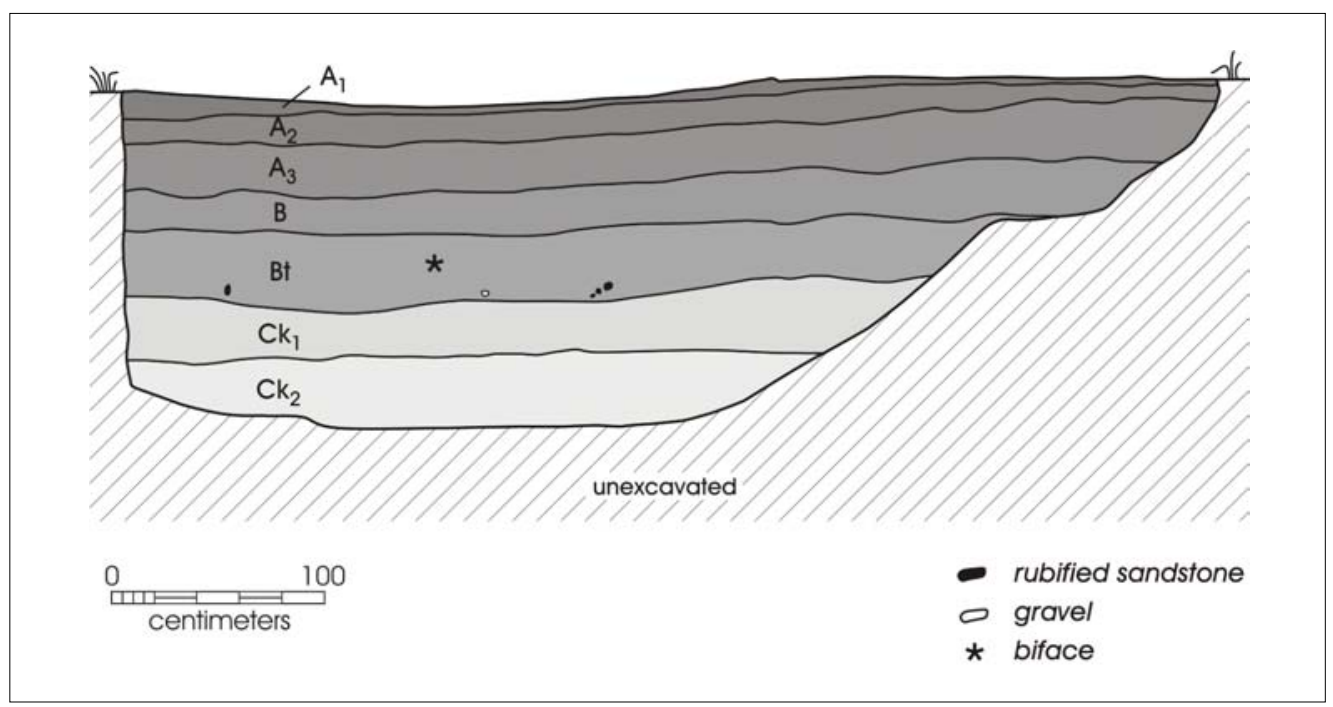

Figure 3-15. East wall profile of Backhoe Trench 26, Field Site 10.

only in BHT 34 where a single flake was recovered at the top of the $\mathrm{C} 3$ horizon at a depth of $113 \mathrm{cmbs}$ (Figure 3-16). This locality is defined as Field Site 11 (Table 3-11).

In addition, a single sample of charcoal was identified and collected from the upper portion of the $\mathrm{C} 2$ horizon in BHT 20 at a depth of $112 \mathrm{cmbs}$ (Figure 3-17). This represented a small concentration of individual flecks of charcoal that were not associated with any evidence of features, artifacts, or an identifiable past ground surface. This was the only charcoal observed during the geoarchaeological investigations.

\section{Phase I Results and Recommendations}

From December 13-17, 2004, CAR conducted Phase I archaeological work on a 160 -acre property near Laredo, Webb County, Texas. The archaeological work consisted of an intensive pedestrian archaeological survey of approximately 132 acres of the property. Within this area, the survey was accompanied by shovel testing and backhoe trenching. In the remaining portion of the project area, representing approximately 28 acres located within the Rio Grande floodplain, no subsurface investigations were conducted and work was limited to surface reconnaissance, at the request of the land owner. Ninety-eight shovel tests and 35 backhoe trenches were excavated across the property. Of the 35 backhoe trenches, 20 were excavated to a depth of $2 \mathrm{~m}$ below surface within the facility footprint. Of the remaining backhoe trenches, five were excavated within the projected easement of the sewer and water lines on the south side of the project area and 10 were excavated across the proposed northeast access road into the facility. These last 15 were excavated to a depth of $1.5 \mathrm{~m}$ below surface.

\section{Summary of Survey Results}

The pedestrian survey, in combination with the geomorphological investigations, resulted in the documentation of 11 field sites (FS 1-11; Figure 3-18, not published). Four of these field sites (FS 1-4) are manifested on surface and also contain artifacts buried to a depth of $60 \mathrm{~cm}$ below surface, the terminal depth of the hand-excavated shovel tests. Three (FS 1, 2, and 4) of the four consist of prehistoric components and the fourth (FS 3 ) is a multi-component site with moderate numbers of historic artifacts and a single piece of debitage. The boundaries of Field Sites 1 and 3 extend beyond the project area to the north. Field Site 2 is within the proposed parking area north of the building footprints. Field Site 4 covers most of the footprint of a proposed building. Field Sites 5-11 were defined based on the presence of small quantities of cultural materials within backhoe trenches.

Field Site 1 measures 14,725 $\mathrm{m}^{2}$ and is located outside of the facility footprint. Seventy-three percent (16 of 22) of the shovel tests excavated on Field Site 1 were positive with a mean of 5.4 prehistoric artifacts per shovel test. Artifacts occurred from Levels 1-6, with peaks in Levels 2 and 5. 


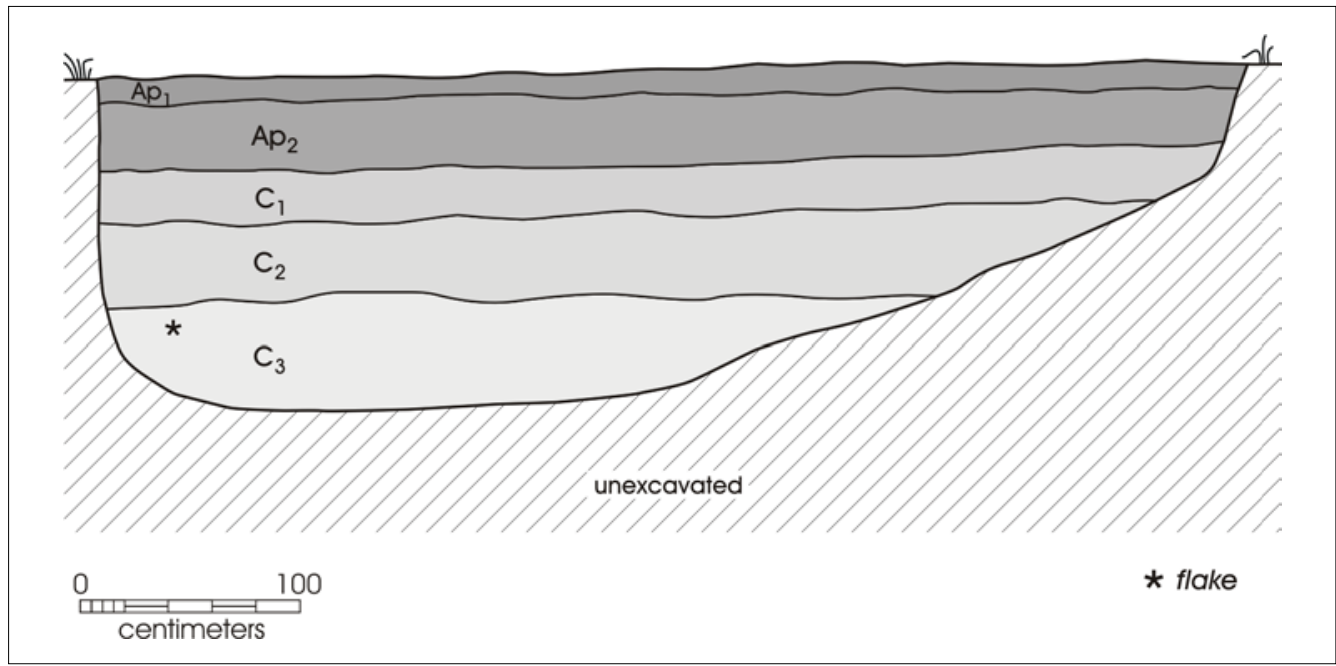

Figure 3-16. North wall profile of Backhoe Trench 34, Field Site 11.

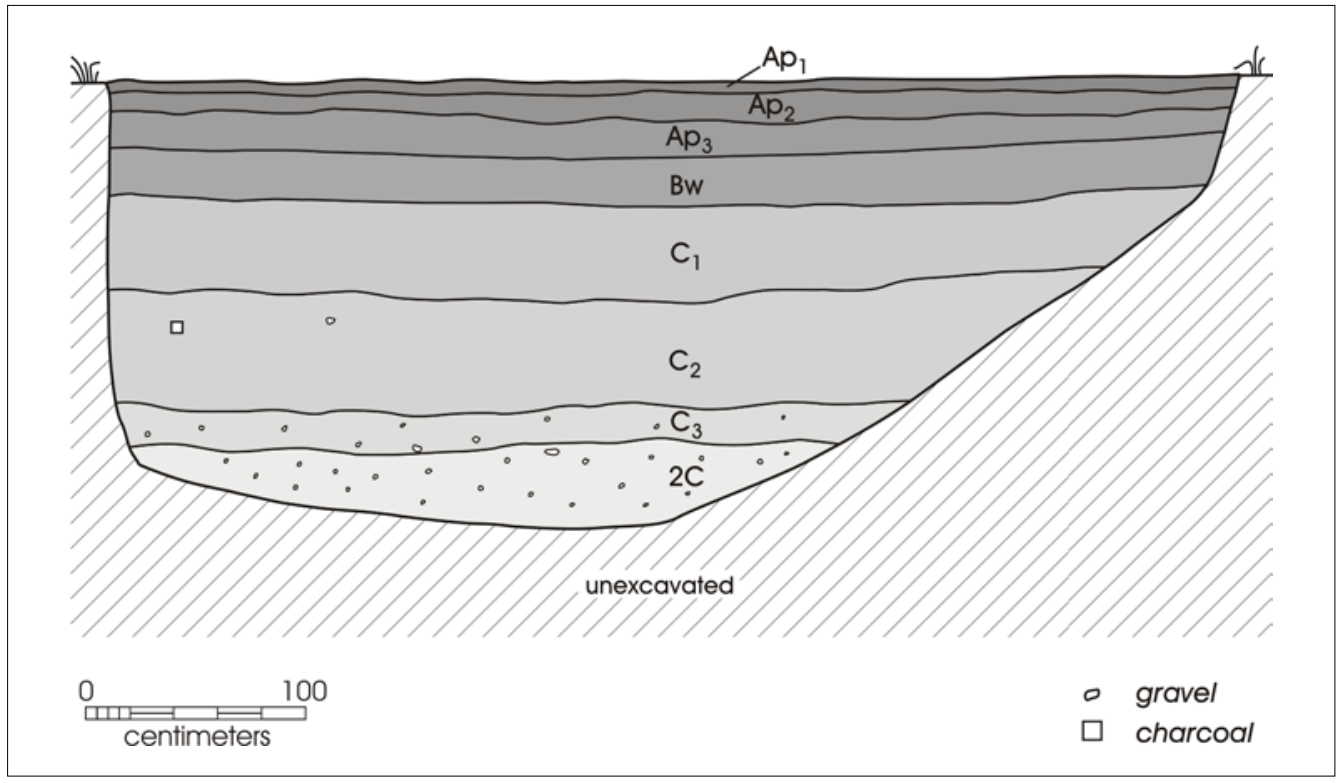

Figure 3-17. North wall profile of Backhoe Trench 20. 
Three of the eight shovel tests excavated by Robert Perry of MACTEC on this site also showed subsurface artifacts from 15-27 cmbs. Overall, 63\% (19 of 30) of the shovel tests excavated on site were positive. No features were identified on site. The age of the component cannot be determined given the lack of prehistoric temporal diagnostics.

Field Site 2 measures $1,947 \mathrm{~m}^{2}$ and is located within the facility footprint. Sixty percent ( 6 of 10) of the shovel tests excavated on site were positive with a mean of 2.3 prehistoric artifacts per shovel test. Artifacts occurred from Levels 16 , with a weak clustering in Levels 1-4. No features were identified on site. At least a portion of the prehistoric component may date to the Late Prehistoric period, judging from the Caracara arrow point recovered from Level 4 (30$40 \mathrm{cmbs}$ ) of ST 74.

Field Site 3 measures $2,015 \mathrm{~m}^{2}$ and is located outside of the facility footprint. It is a multi-component site with abundant historic artifacts and a single chert flake. Eighty-three percent (5 of 6) of the shovel tests excavated on site contained historic artifacts with a mean of 5.4 artifacts per shovel test. Artifacts occurred from Levels 1-5, with a concentration in Levels 3-4. No features were identified on site. The historic component dates from the late nineteenth and early twentieth centuries (1880s-1920s), based on the temporally diagnostic historic surface artifacts recovered primarily by MACTEC during the previous reconnaissance of the property.

Field Site 4 measures $3,120 \mathrm{~m}^{2}$ and is partially located within the footprint of a proposed building. Fifty percent (four of eight) of the shovel tests excavated on site were positive with a mean of 2.6 prehistoric artifacts per shovel test. Artifacts occurred in Levels 1-5, with a small peak in Level 4. No features were identified on site. The age of the component cannot be determined given the lack of prehistoric temporal diagnostics.

Field Sites 5-11 were defined based on prehistoric artifacts noted in the walls (FS 5 and 7-11) or within the backdirt (FS 6) of backhoe trenches excavated within the project area. These cultural manifestations consisted of isolated or minimal densities of debitage and/or bifaces. An exception to this is Field Site 6 where human remains were identified in the backdirt from BHT 6. All archaeological materials were encountered between $63-168 \mathrm{~cm}$ below the current ground surface. Except for a single flake at the base of the plow zone in BHT 16 and the disturbed human remains in BHT 6 , there was no evidence of post-depositional disturbances of the archaeological artifacts. Field Sites 5-9 are located within the paved area of the proposed facility. Field Site 10 is in the proposed access road easement while Field Site 11 is within the sewer and water line easement.

Of these six field sites, Field Site 6 is of particular interest given the identification of one clearly human skeletal fragment - a proximal ulna - and several other smaller unidentifiable bone fragments that are likely to be human. These fragments were identified in the backdirt of the backhoe trench (BHT 6) immediately after the bucket of dirt was removed from the trench, therefore, it is possible to provide an approximate depth to the finds as $80-100 \mathrm{cmbs}$. No additional clearly identifiable cultural remains were recovered from this backhoe trench and the ulna fragment was identified as human in the CAR laboratory following cleaning and comparison with comparative specimens.

Other remains that may or may not be associated with prehistoric occupations of the project area were noted during backhoe trenching. Two mussel shells were identified in BHT 9 at $83-91 \mathrm{cmbs}$ and several pieces of sandstone that did not appear to represent alluvial gravels were identified in both walls of BHT 14 at a depth of $160-168 \mathrm{cmbs}$. A single charcoal sample was identified and collected from BHT 20 at a depth of $112 \mathrm{cmbs}$. Small numbers of surface artifacts were present near almost all of the trenches within the facility footprint but not along the proposed roadway or sewer and water line corridor. Although no features or dense archaeological deposits were encountered, the fine silty clay deposits indicate that cultural materials have a high probability for horizontal and vertical spatial integrity.

In addition to identifying buried cultural materials, the geomorphological investigations were also able to document the alluvial deposits present within the project area. The project area consists of deep silt loams that are primarily Lagloria series soils (Sanders and Gabriel 1985:27-29, 79, Sheet 89) overlying Laredo Formation Eocene sandstones (Groat 1976). The proposed roadway extends eastward across Laredo series silty clay loams and Copita fine sandy loam soils (Sanders and Gabriel 1985:22, 29, 74, 79). The Lagloria soils are calcareous floodplain soils with few clasts that parallel the Rio Grande as narrow terrace deposits. These are commonly used as irrigated pasture land and less often for irrigated crops. There are several visible irrigation ditches across the project area and one or two plow zones were readily apparent in most of the trench profiles. The Laredo silty clay loams form ephemeral drainages and also 
are used for similar economic activities to the Lagloria soils. At the eastern end of the project area, the proposed access road extends through an area mapped as containing Copita fine sandy loam; however, soil descriptions indicate that the majority of the soil examined more closely resembles older time-transgressive expression of the Laredo series floodplain soils. The profiled sections of the facility footprint area and the western portion of the proposed roadway are comparable to those described by Gustavson and Collins (1998:62-65) on one Rio Grande terrace north of Laredo.

These terraces contain primarily low-energy deposits. The texture of the sediments is mostly fine, well-sorted silt loams, loams or clay loams. There are few siliceous gravels present on the ground surface of the main facility area. The potential for preservation of archaeological deposits within these fine, low-energy terrace deposits is excellent. The eastern margin of the proposed roadway location (BHT 30) contained more abundant gravels that appear to be derived colluvially from higher terraces adjacent Highway 83. Gravels were present within $\mathrm{C}$ horizons of five backhoe trenches (BHTs 12, 17, 19,20 , and 31 ) in the western portion of the proposed facility location and in three of the trenches (BHTs 23, 25, and 30) that tested the access road location. Large outcrops of Rio Grande gravels were not seen in the vicinity of the project area. Outcrops of Laredo formation sandstone are apparent along nearby portions of Highway 83 and at the western margin of the $T_{1}$ surface forming $\sim 4 \mathrm{~m}$ high bluffs above the $\mathrm{T}_{0}$ floodplain of the Rio Grande.

\section{Recommendations}

Following the conclusion of the pedestrian survey, at the client's request and with the approval of the Texas Historical Commission reviewer (Debra Beene), CAR produced an interim report detailing the results of the survey and geomorphic investigations (Figueroa et al. 2005). The report also made recommendations regarding the eligibility for NRHP nomination and SAL designation of the newly documented sites. These recommendations are summarized here.

Given the density of prehistoric materials on Field Site 1, CAR recommended limited subsurface testing to investigate the possibility of stratified buried components and determine the ages of these components. Alternately, given that the site limits fall outside of the facility footprint, avoidance of impact to this site was recommended as the preferred strategy.
Due to the presence of a buried Caracara arrow point and the fact that $60 \%$ of the shovel tests produced prehistoric artifacts, CAR recommended limited testing of Field Site 2. Buried and intact Late Prehistoric Caracara components are poorly known and not well documented in South Texas and the possibility that such could exist within the project area was worthy of further investigation.

The multi-component Field Site 3 consists of a single flake representing the prehistoric component and non-diagnostic historic artifacts recovered during shovel testing. The historic component appears to date to the late nineteenth and early twentieth centuries. Therefore, CAR recommended no additional archaeological work at this site.

Field Site 4 is a low-density prehistoric site that lacks temporal diagnostics and intact features. Given its low research potential, CAR recommended no additional work at this site.

Finally, Field Sites 5-11 represented buried archaeological deposits (FS 5 and 7-11) and human remains (FS 6). Given that human remains were found in Field Site 6 (BHT 6), which is within the facility footprint, Phase II testing was recommended to define whether these remains were isolated finds or represented a buried archaeological component. The remaining field sites (FS 5 and 7-11), defined based on finds in backhoe trenches, potentially represented buried cultural remains reflective of prehistoric occupation surfaces. This possibility and the likelihood that they denoted buried archaeological components warranted the recommendation for additional investigation. Therefore, CAR recommended mechanical auger borings in the vicinities of these positive backhoe trenches (BHTs 1, 10, 15, 16, 26, and 34) to establish whether these finds represented buried archaeological components or simply isolated finds.

Following the review of the interim report, these recommendations were approved by the Texas Historical Commission (THC) and CAR produced a scope of work detailing the proposed Phase II testing approach. The scope of work was reviewed by the client and the THC prior to the inception of the Phase II investigations. Following the submission of the interim report for THC review, the client informed CAR that the archaeological component defined at Field Site 1 would not be impacted because it falls outside of the facility footprint. The testing plan outlined in the scope of work for the Phase II testing is presented in the next chapter. 


\section{Chapter 4: Phase II National Register of Historic Places Eligibility and State Archeological Landmark Designation Testing}

From March 1-5 and March 9-18, 2005, CAR conducted Phase II archaeological testing work on the 160-acre property near Laredo, Webb County, Texas, for MACTEC Engineering \& Consulting, Inc. Phase II testing at Field Site 6 was performed between April 2 and April 5, 2005. The purpose of the Phase II archaeological testing was to determine whether any of the eight field sites (FS 2 and 511) for which additional work was recommended following the Phase I survey were eligible for listing in the National Register of Historic Places (NRHP) and/or for formal designation as State Archeological Landmarks (SALs).

The proposed eligibility testing strategy stated that sites found to have intact features, and/or isolable archaeological components that contain artifacts representative of aspects of the lithic technology, and/or good faunal preservation indicative of diet and subsistence practices, and temporally diagnostic artifacts or datable organic materials were to be considered eligible for NRHP nomination and/or formal SAL designation. Sites with multiple components characterized by poor stratigraphic integrity, or low-density cultural deposits that lack datable materials and/or temporally diagnostic specimens, would not be considered eligible for nomination and/or formal designation.

The following section outlines the Phase II testing strategy used at each of the eight sites. Subsequently, the methods employed for the excavation of mechanical auger borings, backhoe trenches and the hand excavation of 1-x-1-m and $50-\mathrm{x}-50-\mathrm{cm}$ units is discussed in detail. Given that Field Sites 2 and 6 are somewhat different from the other six, the testing methods recommended by CAR were uniquely tailored for each of these sites. On the other hand, since Field Sites 5 and $7-11$ were rather similar, the field methods proposed for the investigation of each of these were alike.

\section{Field and Laboratory Methods}

\section{Testing Strategy}

Field Site 2 was tested using five 1-x-1-m hand-excavated test units across the site limits in the vicinity of positive shovel tests and/or surface artifact concentrations (Figure 4-1). The goal of the excavation of these units was to establish whether an isolable and undisturbed Late
Prehistoric component was present on site as suggested by the previous work. Given that the upper $30 \mathrm{~cm}$ of the site's deposits have been impacted by root plowing and possibly chaining, the manual excavations commenced after the upper $30 \mathrm{~cm}$ of matrix was removed by hand using shovels. Furthermore, because the previous investigations documented archaeological materials from $30-60 \mathrm{cmbs}$, the hand excavations of the 1-x-1-m units continued for five levels to a depth of $80 \mathrm{cmbs}$. This allowed us to extend the investigations approximately $20 \mathrm{~cm}$ below the projected subsurface impacts (estimated at $2 \mathrm{ft}$.) within the facility footprint.

In addition to the work summarized above, magnetic susceptibility samples were collected from an area adjacent Test Unit E (TU E; Figure 4-1). As discussed in Appendix D, magnetic susceptibility can help document the presence of buried surfaces, as well as organics and heating of sediments often associated with cultural occupation on such a surface. Samples were collected using a bucket auger, and sampling was at $10-\mathrm{cm}$ intervals from the surface down to $90 \mathrm{cmbs}$.

For Field Site 6, the site with the disturbed human remains, the proposed testing strategy had to be modified due to difficulties relocating BHT 6. First, the original testing strategy is discussed in detail followed by a description of the actual work performed at the site. Originally, CAR proposed to re-excavate BHT 6 to a depth of $150 \mathrm{cmbs}$. Once the trench was reopened, CAR proposed to excavate a 1-x-2-m unit off one of the walls of the trench to investigate in greater detail the vicinity of the location from where the remains were recovered. Note that it was not possible to ascertain during survey exactly where from within the trench the human remains were recovered. Proveniences within the 1-x-2-m unit were to be tied to the individual 1-x-1-m units but the two units were to be excavated concurrently so that each level was entirely excavated in both units before proceeding to the next level.

In addition to the 1-x-2-m unit, three isolated 1-x-1-m units were to be excavated within a 30-m diameter circle centered on BHT 6 to investigate in a cautious manner whether any additional human remains were present in the area. As in the case of Field Site 2, it was proposed that the upper $30 \mathrm{~cm}$ of deposits be scraped off the top of each excavation unit. The Phase I geomorphic work had documented that these deposits have been disturbed through plowing and chaining. 


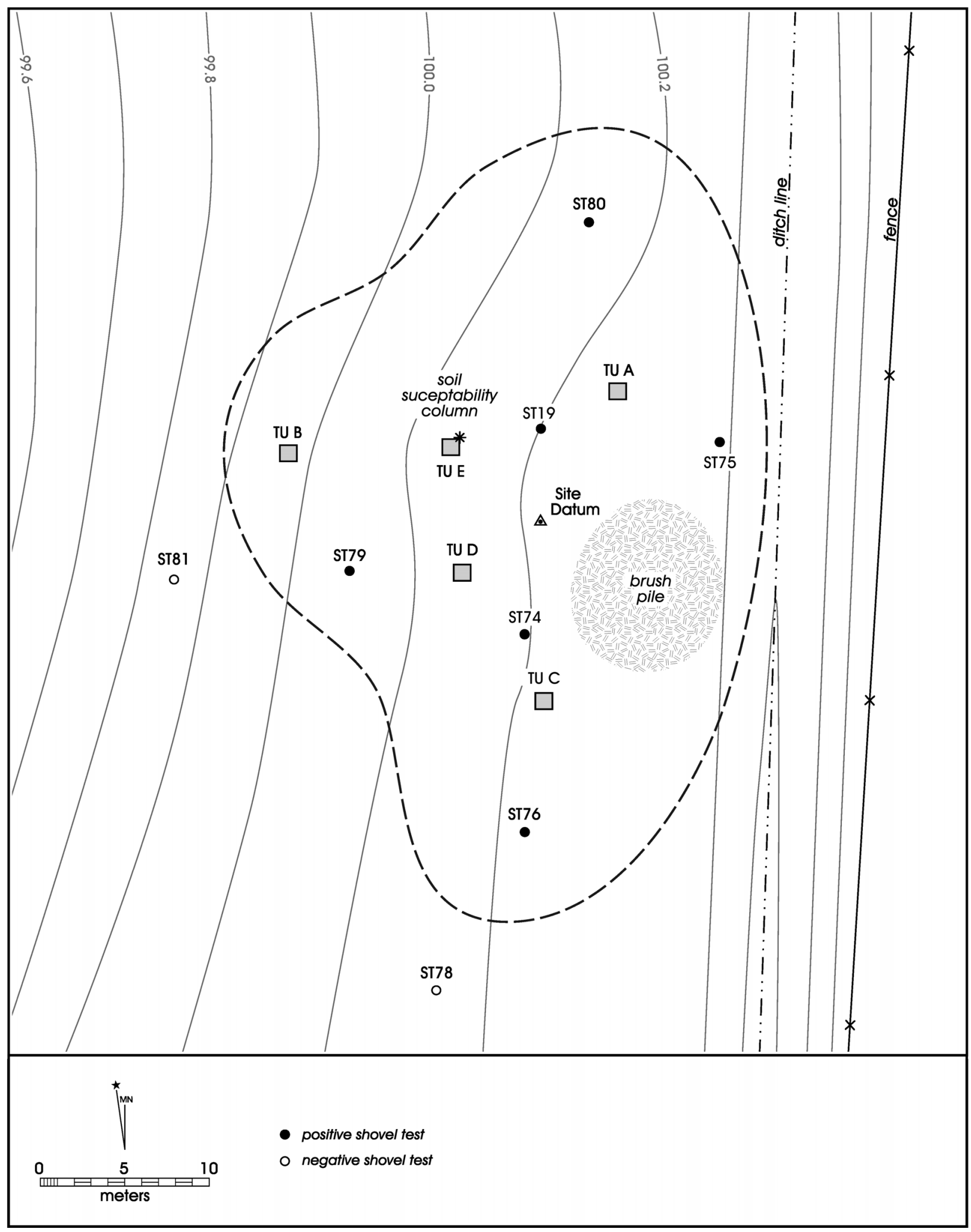

Figure 4-1. Map of Field Site 2 showing locations of hand-excavated units and shovel tests. 
Difficulties were encountered when trying to relocate BHT 6 and a third visit to the project area was required to complete the Phase II testing (April 2-5, 2005). Time constraints obligated us to modify the proposed testing strategy. First, BHT 6 was reopened to a depth of $185 \mathrm{cmbs}$. Once the backhoe trench was reopened, a 1-x-2-m test unit composed of Test Units 1 and 2 was located about $0.5 \mathrm{~m}$ southwest of the southern wall of BHT 6 (Figure 4-2). A 1-x-1-m unit (TU 3) was excavated off the northeast side of the northern wall of BHT 6. Proveniences within the 1-x-2-m unit were tied to the individual $1-\mathrm{x}-1-\mathrm{m}$ units. The two units were excavated concurrently so that each level was entirely excavated in both units before proceeding to the next level. The upper $40 \mathrm{~cm}$ of deposits from the top of each excavation area within the 1-x-2-m unit were scraped off manually using shovels. Hand excavations began after the upper $40 \mathrm{~cm}$ of deposits were removed and continued in arbitrary $10-\mathrm{cm}$ levels to a depth of $150 \mathrm{cmbs}$ in TU 1 and $160 \mathrm{cmbs}$ in TU 2. In the case of TU 3, the top $60 \mathrm{~cm}$ of deposits were removed prior to the hand excavation of the unit. Hand excavations began after removal of the upper deposits and continued to a depth of $160 \mathrm{cmbs}$. In the case of each test unit, the overburden removed by shoveling represented the plow zone.

A total of five additional backhoe trenches was excavated in the vicinity of Field Site 6 (BHT 6-1 to BHT 6-5). Figure 4-2 shows the locations of the backhoe trenches. Depths of the backhoe trenches ranged from $175 \mathrm{cmbs}$ to $210 \mathrm{cmbs}$. Table 4-1 shows the final depths of each of the additional backhoe trenches excavated at Field Site 6 as well as their orientation. Excavation of the backhoe trenches was monitored by an archaeologist. The backdirt piles were carefully examined for the presence of cultural material and human remains. The walls of each backhoe trench were examined as well.

In Field Sites 5, 10, and 11, the backhoe trenches revealed that the deepest cultural remains occur at a maximum depth of $113 \mathrm{cmbs}$ (FS 11, BHT 34). Because a four-foot auger can reach to this depth, it was proposed to combine systematic mechanical auger borings and hand excavations to investigate the nature and extent of buried cultural deposits in the vicinity of the positive backhoe trenches that defined these field sites.

Twenty-four mechanically excavated auger borings were excavated within a 32-x-32-m area centered on each of the positive backhoe trenches that defined the sites. The auger bore located in the center of each backhoe trench (auger bore number 13 in each case) was marked, but not excavated as the area was already inspected during backhoe trenching. The auger borings were positioned $8 \mathrm{~m}$ apart and were excavated in three 40 -cm increments to a depth of 120 cmbs. Subsequently, the positive backhoe trench on each site was re-excavated and one $50-\mathrm{x}-50-\mathrm{cm}$ unit was excavated off one wall of each trench. Excavation proceeded to a depth of $120 \mathrm{cmbs}$ in each unit. Figures 4-3, 4-4, and 4-5 show the locations of the auger bores and $50-\mathrm{x}-50-\mathrm{cm}$ handexcavated units at Field Sites 5, 10, and 11.

At Field Sites 7, 8, and 9, the backhoe trenches revealed that the deepest cultural remains occur at a maximum depth of $155 \mathrm{cmbs}$ (FS 8, BHT 15). Even though a four-foot auger can reach only to an approximate depth of $120 \mathrm{cmbs}$, CAR felt that systematic mechanical auger borings in combination with hand-excavated units would be an effective means of examining deposits to a depth of $150 \mathrm{cmbs}$. It was assumed that the auger borings would allow systematic inspection of the upper $120 \mathrm{~cm}$ of deposits while the remaining $30 \mathrm{~cm}$ would be investigated using hand-excavated units.

As in the case of the previous three field sites, 24 auger borings were mechanically excavated within a $32-x-32-m$ area centered on each of the positive backhoe trenches that defined the sites. The auger borings were positioned $8 \mathrm{~m}$ apart and were excavated in three $40-\mathrm{cm}$ levels to a depth of $120 \mathrm{cmbs}$. The auger borings were placed so that number 13 was located in the center of each positive backhoe trench. In each case, auger boring number 13 was marked but not excavated. Following the auger testing, the positive backhoe trench on each site was re-excavated and one additional backhoe trench was excavated to a depth of $150 \mathrm{cmbs}$ on each of the three field sites. The placement of the second backhoe trench was at the discretion of the project archaeologist and conditioned by the recovery of cultural materials from the auger borings. Once the stratigraphy of the newly excavated trenches was documented, a 50-x-50-cm unit was manually excavated off one wall of each of the two trenches present at each field site. Excavation proceeded to a depth of $150 \mathrm{cmbs}$ in each unit, given that this would encompass the deepest cultural remains found at any of the three field sites. Figures 4-6 to 4-8 illustrate the locations of the backhoe trenches, hand-excavated units, and auger bores at Field Sites 7,8 and 9.

On Field Site 8, magnetic susceptibility samples were collected at $5-\mathrm{cm}$ intervals from the face of one of the 50-x$50-\mathrm{cm}$ test units (TU H). Twenty-nine samples were collected from the surface down to $145 \mathrm{cmbs}$. A similar 


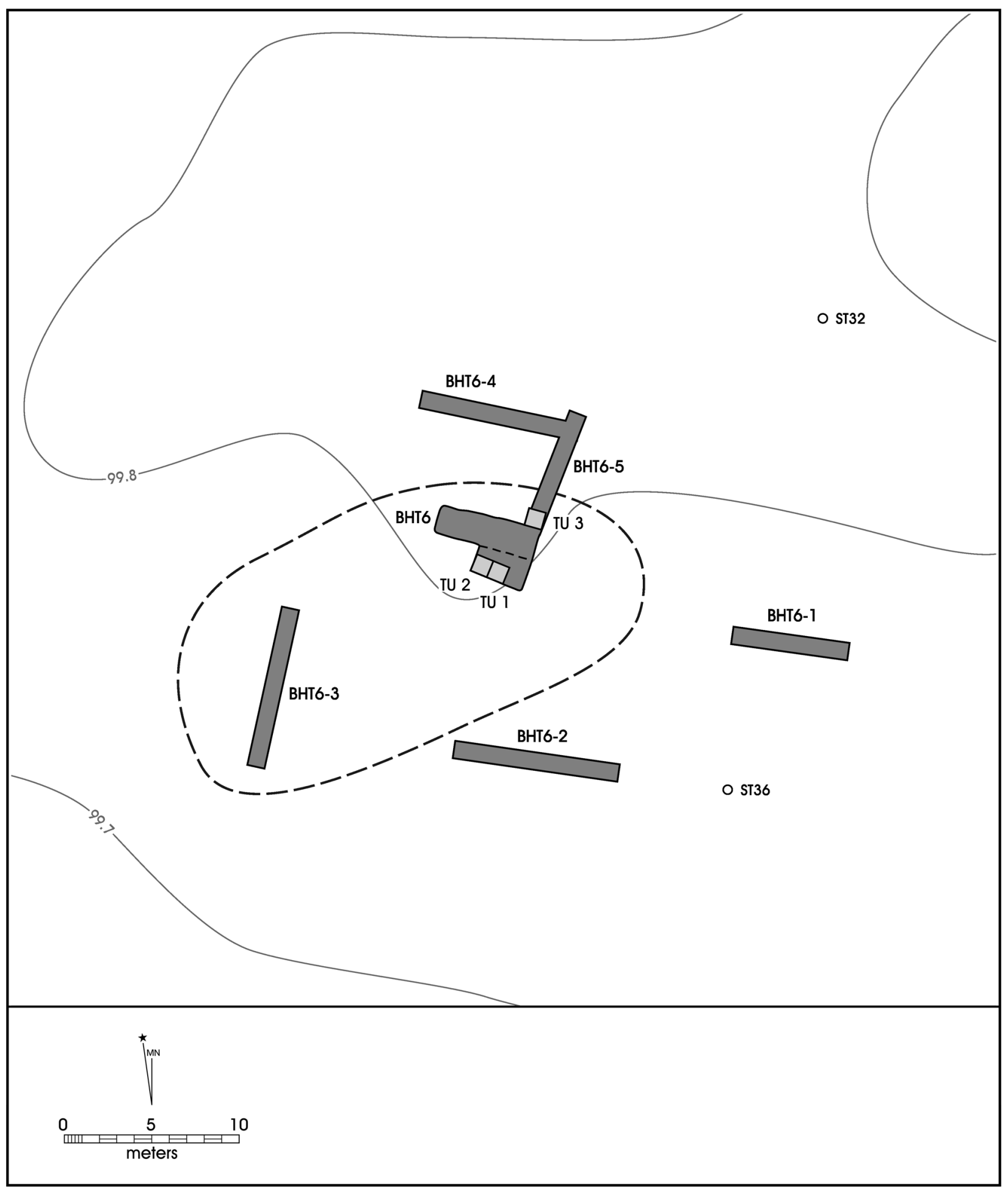

Figure 4-2. Map of Field Site 6 showing locations of hand-excavated units and backhoe trenches. 
collection strategy was employed on Field Site 9 with susceptibility samples collected at $5-\mathrm{cm}$ intervals from TU J, a 50-x-50-cm unit. As with the Field Site 8 collections, samples were taken from the surface down to $145 \mathrm{cmbs}$ (see Appendix D).

\section{Field Methods Employed}

As mentioned, excavation methods included mechanically excavated auger borings and backhoe trenches, and handexcavated 1-x-1-m, 1-x-2-m, and 50-x-50-cm units. The actual methods of excavation are described below.

\section{Auger Borings}

The auger borings were $23 \mathrm{~cm}$ (9 inches) in diameter excavated to a maximum depth of $120 \mathrm{~cm}$ below surface, unless otherwise prevented from reaching this depth. They were excavated in three $40-\mathrm{cm}$ levels. All sediments removed from these tests were screened through 1/4-inch mesh, all artifacts were collected, and observations on the borings were recorded on standardized forms. A form was completed for every excavated auger bore. Data collected from each auger bore included details of recovery in each $40-\mathrm{cm}$ level, including a notation on any cultural materials recovered, a brief soil description (texture, consistence, color, natural clasts), and any other information considered pertinent to evaluating the archeological potential of these deposits.

\section{Backhoe Trenches}

The re-excavation of the previously excavated trenches proceeded according to the following protocol. Trenches were excavated to their original dimensions. At least one of the originally excavated walls where cultural materials had been noted during profiling was exposed during reexcavation. Once the wall was exposed, a portion of the wall measuring roughly $1-2 \mathrm{~m}$ was hand-cleaned in the area designated for the placement of the hand-excavated unit.

Newly excavated trenches were approximately $10 \mathrm{~m}$ long and did not exceed a maximum of $1.5 \mathrm{~m}$ in depth. Backhoe trenches excavated in the vicinity of FS 6 were an exception due to the unique circumstances surrounding the testing of the site. Refer to Table 4-1 for depths of the additional backhoe trenches in FS 6. An archaeologist monitored the excavation of each of the backhoe trenches. In addition, the backdirt piles were carefully examined for presence of cultural material or possible human remains. One wall of each backhoe trench was profiled and drawn or the profile
Table 4-1. Final Depths and Orientation of Backhoe Trenches, Field Site 6

\begin{tabular}{|c|c|c|}
\hline BHT Number & Depth (cmbs) & Orientation \\
\hline $6-1$ & 175 & E-W \\
\hline $6-2$ & 185 & E-W \\
\hline $6-3$ & 195 & N-S \\
\hline $6-4$ & 195 & E-W \\
\hline $6-5$ & 210 & N-S \\
\hline
\end{tabular}

was correlated with the profiles recorded during the Phase I survey if enough similarities justified this undertaking. Both walls were troweled and examined for evidence of any potential archaeological artifacts, features, or significant indicators of formation events. Soil descriptions were performed, however, full soil descriptions were not necessary for all profiles as similar soils and sediments could be correlated across trenches. Color digital images of a representative sample of the exposed profiles were taken. All cultural materials noted in profiles were collected.

\section{Hand-excavated $1-x-2-m, I-x-1-m$, and 50-x-50-cm Units}

The 1-x-2-m, 1-x-1-m and/or 50-x-50-cm units were excavated in 10-cm levels. Excavations were performed using trowels, shovels, hand picks or a combination of all three. All matrix from these units was screened through 1/4-inch mesh and all materials were collected and bagged by level.

\section{Mapping Procedures}

Mapping procedures started in the field when crew members recorded the locations of any diagnostic artifacts using a GPS unit. Only the locations of diagnostic artifacts were recorded. The locations of diagnostic artifacts were also sketched onto aerial photographs and a 1:24,000-scale USGS topographic map. Isolated finds (single specimens), defined as artifacts found at a distance of $30 \mathrm{~m}$ or more from other surface cultural materials, were also mapped with a GPS unit. Likewise, CAR surveyors took GPS readings on the locations of all shovel tests, auger bores, backhoe trenches, site datums, and points along the perimeters of site boundaries. These were also sketched onto aerial photographs and topographic maps. Sketch maps illustrating the locations of site boundaries, site datums, shovel tests, collected items, areas of high artifact density, and physical features on the landscape were also produced in the field. 


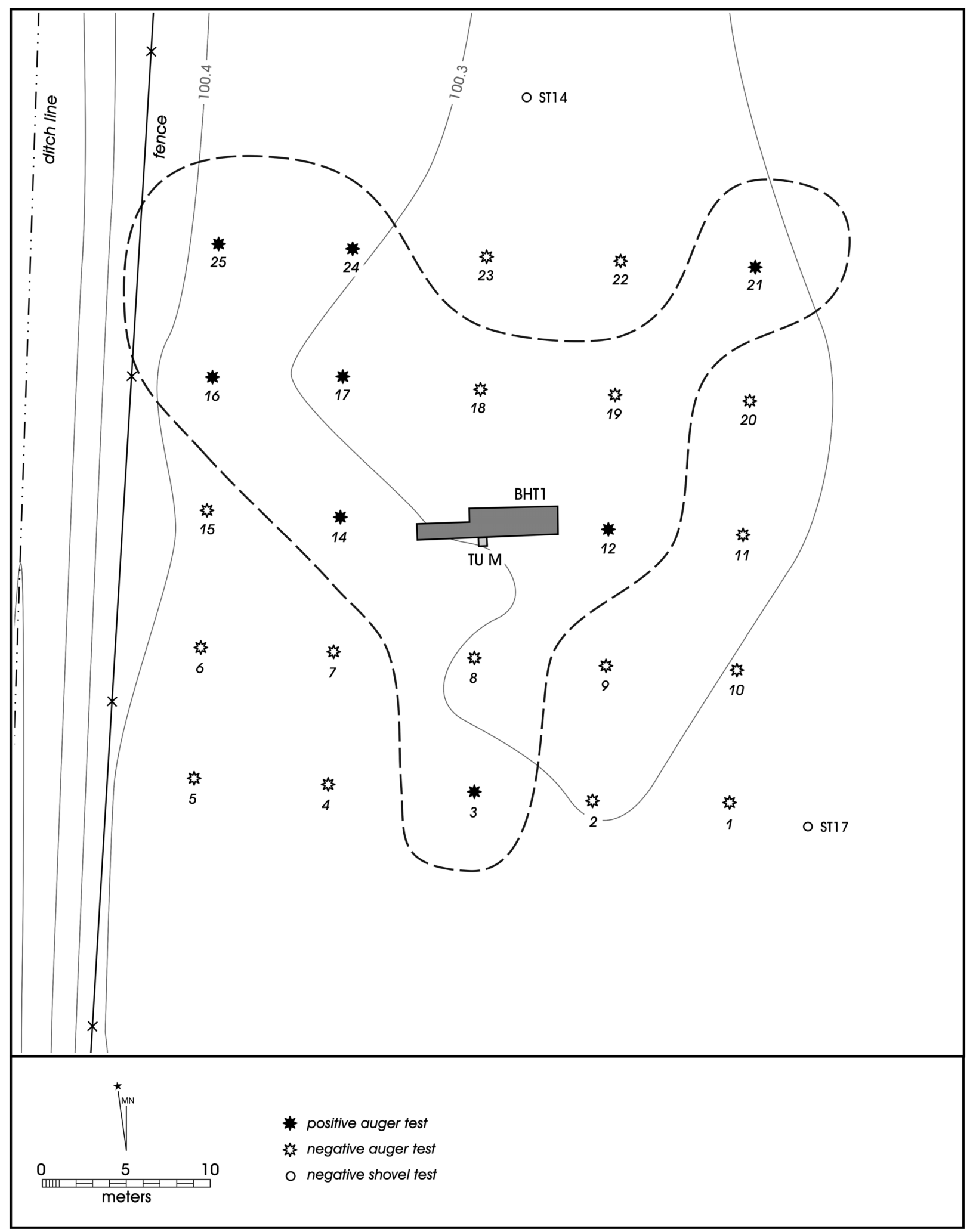

Figure 4-3. Map of Field Site 5 showing locations of auger bores, the backhoe trench, and the 50-x-50-cm unit (TU M). 


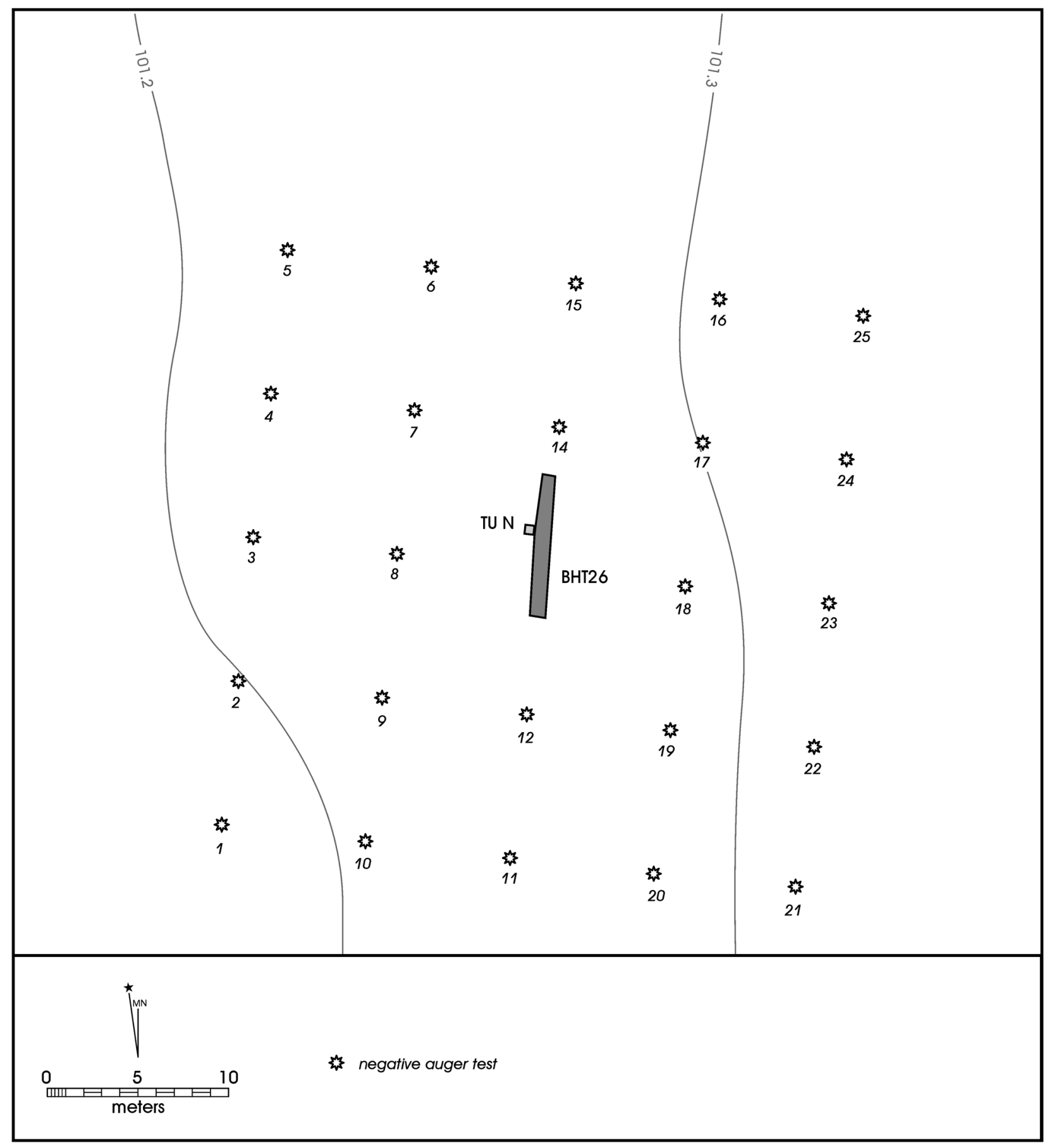

Figure 4-4. Map of Field Site 10 showing locations of auger bores, the backhoe trench, and the 50-x-50-cm unit (TU N). 


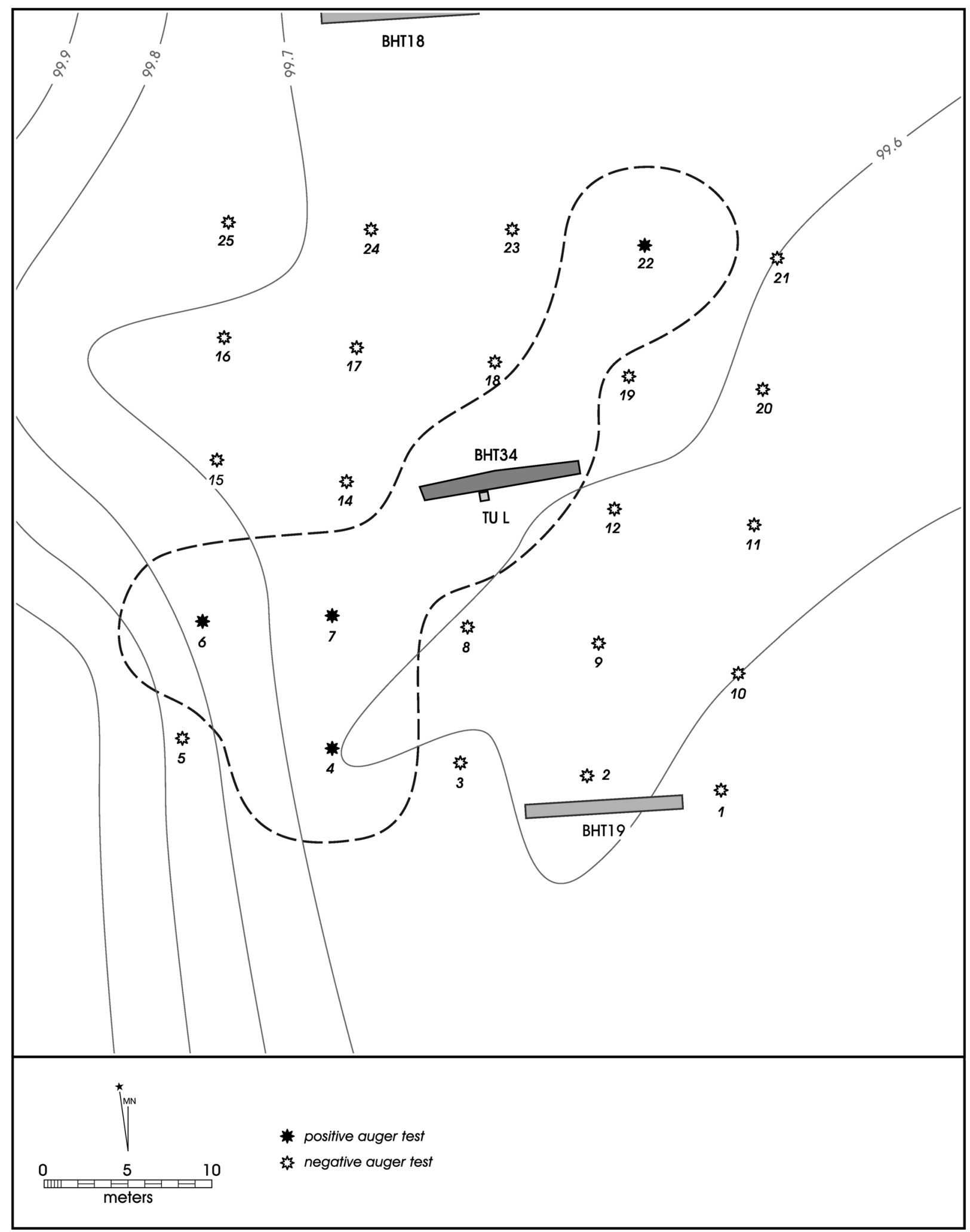

Figure 4-5. Map of Field Site 11 showing locations of backhoe trenches, auger bores and the 50-x-50-cm unit (TU L). 
Subsequently, as a part of the Phase II testing, CAR staff used a Sokkia 6E Total Data Station (TDS) and a SDR33 data collector to collect both plan-view data and topographically oriented spatial data for revising and creating topographic maps and plan views. During this process, a series of control points were placed across the project area and excavation controls (i.e., datums, control points) were tied together. The TDS was then used to collect spatial information related to site boundaries, locations of units, shovel tests, auger borings, and physical features on the landscape. The GPS data was downloaded using Pathfinder Office and processed using ARCGIS to produce the maps and sketches accompanying this report and the site forms submitted to the Texas Archeological Research Laboratory. The TDS data was processed using Surfer and Carlson Survey Software.

\section{Laboratory Methods}

All cultural materials obtained during the excavations or profile descriptions were retained and returned to the CAR laboratory for processing and analysis. The initial processing consisted of the cleaning of the materials and their sorting into analytical categories (i.e., debitage, stone tools, etc.). Provenience labels were included in each newly bagged artifact category prior to providing them to the analyst.

Individual categories were then analyzed by specific attributes designed for each group. All data was entered into an Excel spreadsheet. Subsequent to proper analyses and/ or quantification, and in consultation with the client and the landowner, some artifact classes possessing little scientific value were discarded. Artifact classes discarded include snail shell, natural rocks, modern glass, unidentifiable metal fragments, plastic, and heat spalls. In all instances, however, discarded materials were documented and their counts included in the final report and curation documentation.

After the analyses of the artifact were completed, the artifacts were temporarily stored at the CAR facility until the acceptance of the draft report by the Texas Historical Commission. Following that, the artifacts were returned to the landowner. All records generated during the project were prepared in accordance with federal regulation 36 CFR part 79, and Texas Historical Commission requirements for State Held-in-Trust collections. Field notes, forms, photographs, and drawings were placed in labeled archival folders. Photographs, slides, and negatives were labeled with archivally appropriate materials and placed in archivalquality sleeves. All field forms were completed with pencil.
Documents and forms were printed on acid-free paper and any soiled forms were placed in archival-quality page protectors. Maps and illustrations produced by ink-jet printers also were placed in archival-quality page protectors. A copy of this report and all computer disks pertaining to the investigations are curated at CAR with the field notes and documents. Also, State of Texas Archeological Data Site Forms were completed for each archaeological site defined during this project. 


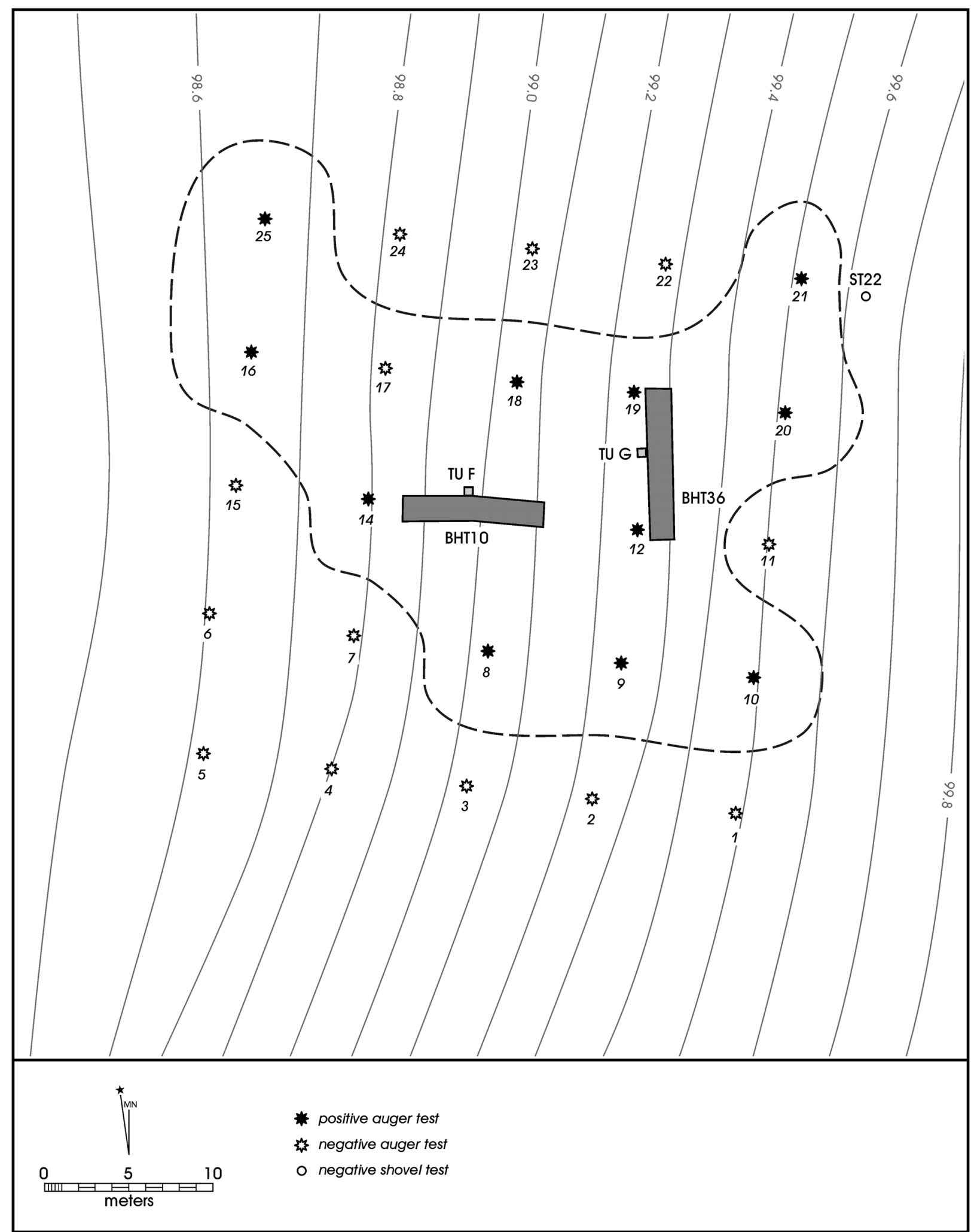

Figure 4-6. Map of Field Site 7 showing locations of auger bores, the shovel test, 50-x-50-cm units, and backhoe trenches. 


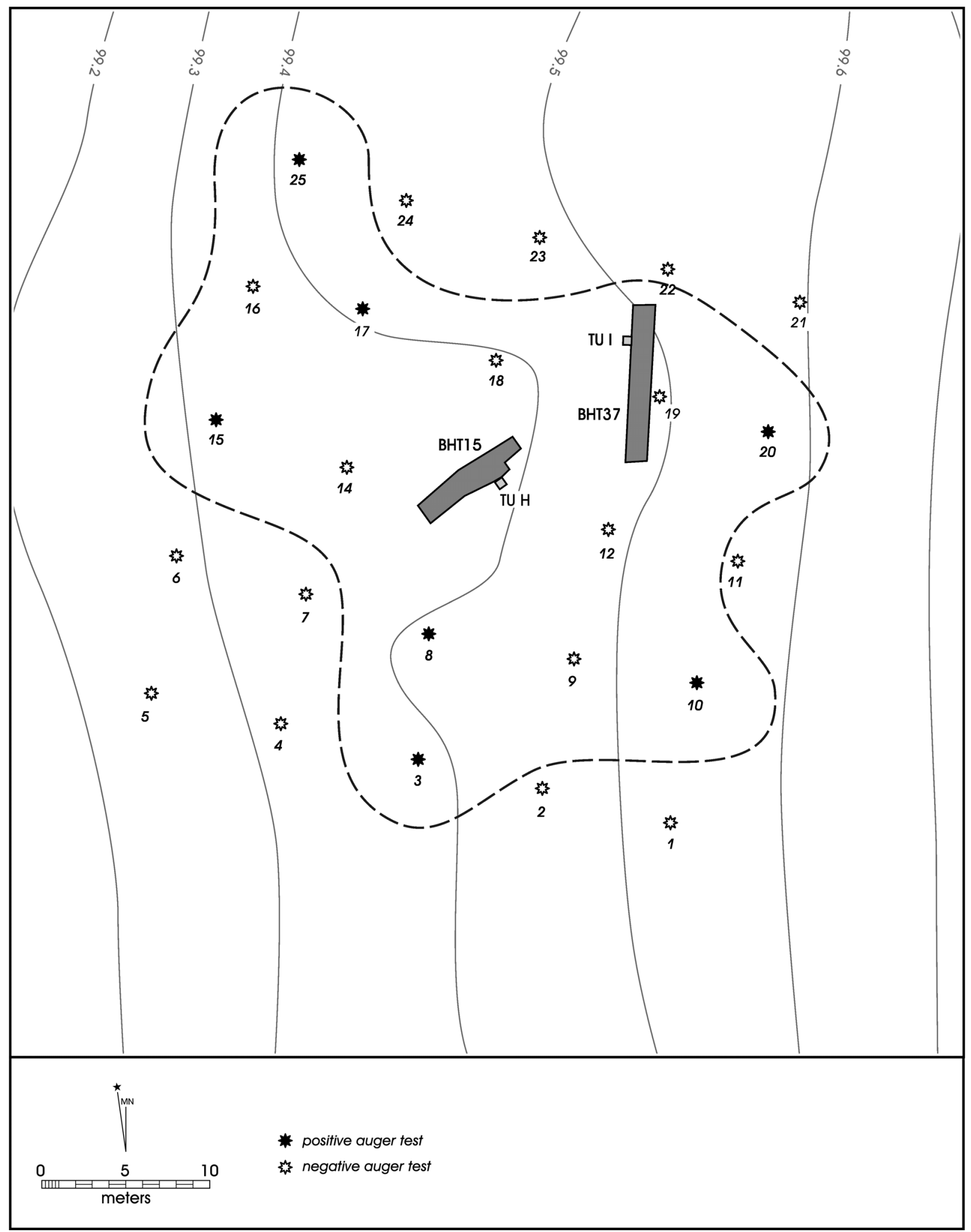

Figure 4-7. Map of Field Site 8 showing locations of auger bores, 50-x-50-cm units, and backhoe trenches. 


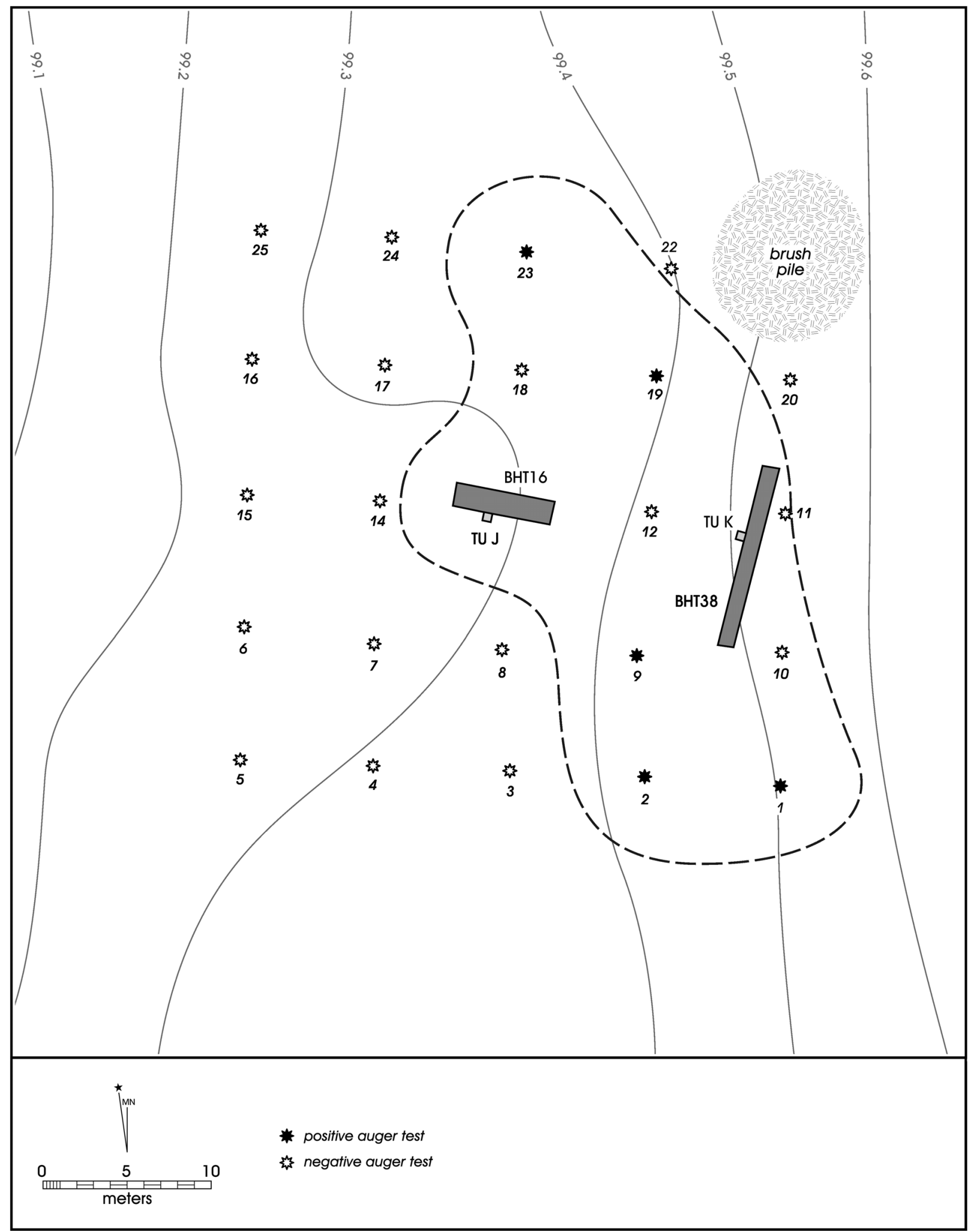

Figure 4-8. Map of Field Site 9 showing locations of auger bores, 50-x-50-cm units, and backhoe trenches. 


\section{Chapter 5: Phase II Testing Results and Recommendations}

Phase II testing was performed on eight of the 11 field sites identified by the Phase I survey. No Phase II testing was recommended by CAR at Field Sites 3 and 4 and no work was performed at Field Site 1 since it falls outside the facilities footprint and will not be impacted by construction. Based on the data gathered by the Phase I and Phase II efforts, as well as the data recovered during the reconnaissance work done by MACTEC, a total of seven archaeological sites was reported to the Texas Archeological Research Laboratory (TARL) and assigned state trinomials. These include sites 41WB634 (FS 1), 41WB636 (FS 3), 41WB637 (FS 5), 41WB638 (FS 6), and 41WB640 (FS 11). No additional discussions are included for sites 41WB634 and 41WB636. The reader is referred to Chapter 3 of this report for descriptions of these sites. Also, following the compilation of the survey and testing results, the boundaries of Field Sites 2, 4, and 7 were combined into 41WB635 (FS 2b), and the boundaries of Field Sites 8 and 9 were combined into $41 \mathrm{WB} 639$ (FS 8b). Table 5-1 presents the field site numbers and the state trinomials as defined following the Phase II testing.

The same site definition used for the survey was used for the testing fieldwork. A site was defined as a location containing either (1) five or more surface artifacts within a 15 -m radius (ca. $706.9 \mathrm{~m}^{2}$ ) or; (2) a location containing a single cultural feature, such as a hearth, either on surface or exposed in a shovel or auger test or; (3) a location with a positive shovel test or backhoe trench containing at least three artifacts within a given 10-cm level or section of trench or at least four artifacts within any auger level $(40 \mathrm{~cm})$ or; (4) a location with a positive shovel or auger test containing at least five total artifacts or; (5) two positive shovel or auger tests or two positive backhoe trenches located within $30 \mathrm{~m}$ of each other. All other artifacts were classified as isolated occurrences or finds.

Once the testing phase was concluded, all GPS data from the reconnaissance survey performed by MACTEC and the Phase I and Phase II data were combined. It is important to note that at the time of the Phase I investigations, the GPS data from MACTEC's reconnaissance survey was not available to CAR. Once the surface and subsurface data was examined as a single entity, it became apparent that the distances between some of the sites were less than $30 \mathrm{~m}$. Based on the previously provided definition of a site, it was decided to combine several smaller sites into larger sites. As a result, site 41WB635 (FS 2b) was defined as including previous Field Sites 2, 4, and 7 while site 41WB639 (FS 8b) was defined as including Field Sites 8 and 9. In this chapter, all the sites tested during the Phase II work are discussed in detail.

\section{Site 41WB635 (Field Site 2b)}

Site 41WB635 is a Late Prehistoric site with a surface and subsurface distribution of lithic debitage and lithic tools (Figure 5-1). It is located in the central portion of the project area on an upper terrace east of the Rio Grande. A fence line oriented north-south runs to the east of the site. The site is approximately $9,777 \mathrm{~m}^{2}(2.42$ acres $)$ in size. At the time of the fieldwork, surface visibility on the site was poor (less than 5\%). Surface inspection as well as a total of 13 shovel tests, 24 auger bores, two $50-\mathrm{x}-50-\mathrm{cm}$, five 1-x-1-m units, and two backhoe trenches were completed at the site. Cultural material was encountered to a maximum depth of $100 \mathrm{cmbs}$.

Table 5-1. Correspondence Between Trinomial, Field Site and Provisional Site Numbers

\begin{tabular}{|c|c|c|c|}
\hline State Trinomial & Phase I Field Site \# & Field Site \# after Phase II & MACTEC Provisional Site \# \\
\hline $41 \mathrm{WB} 634$ & FS 1 & FS 1 & 1 and 3 \\
\hline $41 \mathrm{WB} 635$ & FS 2, FS 4, and FS 7 & FS 2b & 4 \\
\hline $41 \mathrm{WB} 636$ & FS 3 & FS 3 & 2 \\
\hline $41 \mathrm{WB} 637$ & FS 5 & FS 5 & \\
\hline $41 \mathrm{WB} 638$ & FS 6 & FS 6 & \\
\hline $41 \mathrm{WB} 639$ & FS 8 and FS 9 & FS 8b & \\
\hline $41 \mathrm{WB} 640$ & FS 11 & FS 11 & \\
\hline
\end{tabular}




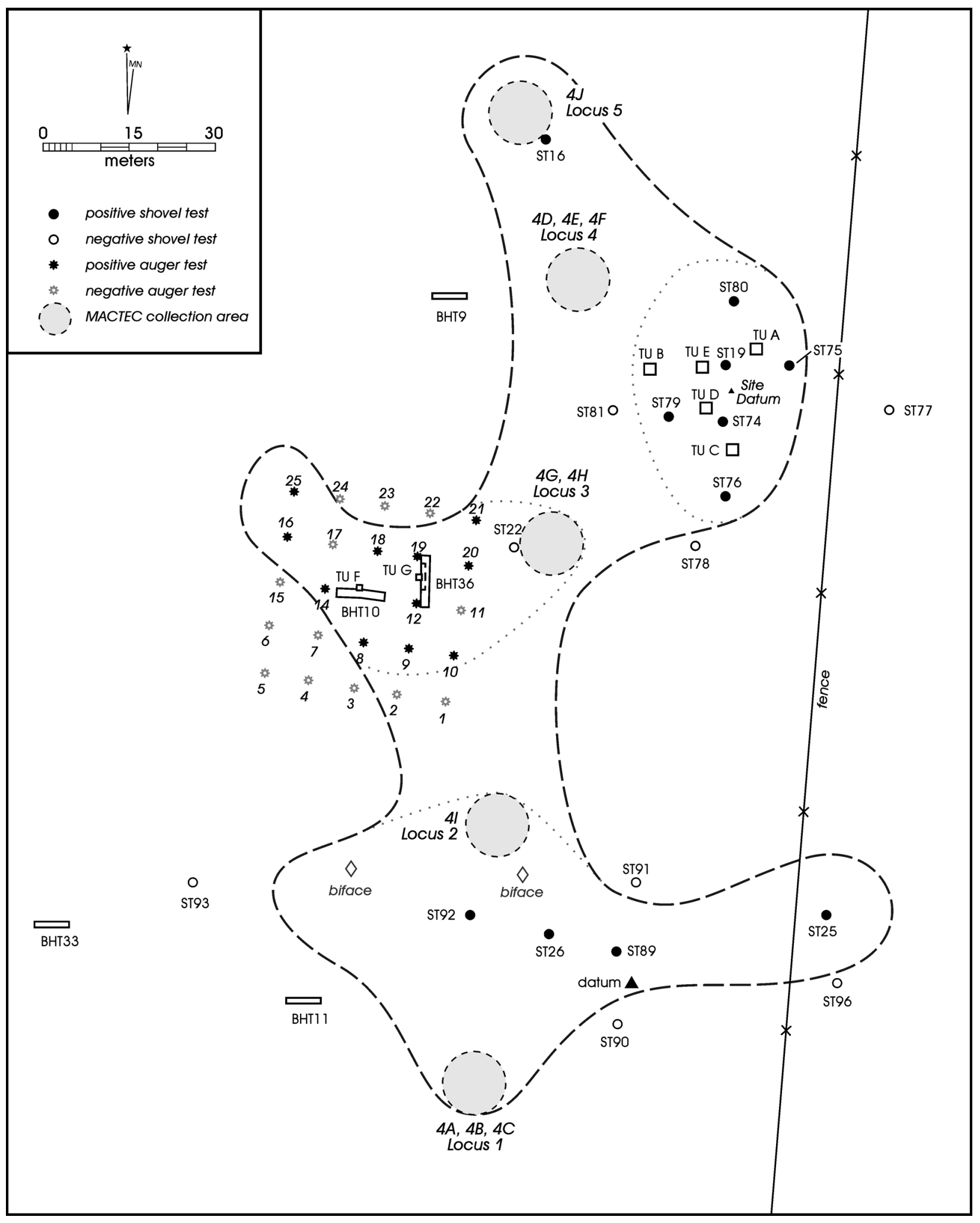

Figure 5-1. Map of site 41WB635 (FS 2b) showing locations of auger bores, test units, shovel tests, and backhoe trenches. 
A moderate to high amount of cultural material including a Caracara arrow point (Figure 5-2), lithic debitage $(n=247)$, lithic tools and cores $(n=5)$, burned rock, mussel shell fragments, and small charcoal fragments were recovered from the site (Tables 5-2, 5-3 and 5-4). Modern artifacts were encountered scattered on the surface of the site and a small number of modern items were encountered in the test units (TU A, one unidentified metal fragment) and shovel tests (ST 92, one piece of modern glass) to a depth of 50$60 \mathrm{cmbs}$. The surface collection made by MACTEC (Perry 2004) indicate lithic debitage scattered across the site in a north-south direction following a line of surface disturbance.

Three concentrations of artifacts were identified on site. The southernmost concentration (originally FS 4) consists mostly of lithic debitage encountered on the surface and to a depth of $50 \mathrm{cmbs}$. Two bifaces were observed on surface, and one is illustrated in Figure 5-3. The westernmost concentration (originally FS 7) consists of lithic debitage found on the surface and to a depth of $100 \mathrm{cmbs}$. One core and a biface were recovered from the surface and another biface fragment was recovered at $30 \mathrm{cmbs}$. The easternmost concentration

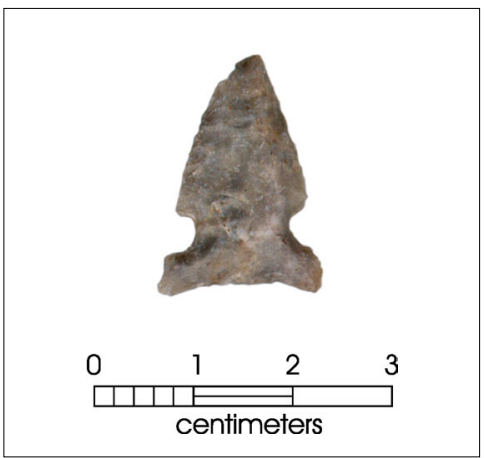

Figure 5-2. Caracara arrow point recovered from $41 \mathrm{WB} 635$ ( $F S 2 b$ ).

is represented by one diagnostic Caracara arrow point dating to the Late Prehistoric period recovered from Level 4 (30-40 cmbs) of ST 74 and lithic debitage that extends to a depth of $80 \mathrm{cmbs}$. Likewise, one core was collected from TU E, Level $1(30-40 \mathrm{cmbs})$ and a biface was observed on the surface.

Table 5-2. Cultural Material from Shovel Tests at 41WB635 (FS 2b)

\begin{tabular}{|c|c|c|c|}
\hline Shovel Test & Depth (cmbs) & Artifact Class & Count \\
\hline 2 & $0-10$ & Debitage & 1 \\
\hline 19 & $0-10$ & Debitage & 1 \\
\hline 19 & $20-30$ & Debitage & 1 \\
\hline 19 & $30-40$ & Debitage & 1 \\
\hline 19 & $50-60$ & Debitage & 1 \\
\hline 25 & $0-10$ & Debitage & 1 \\
\hline 25 & $20-30$ & Debitage & 1 \\
\hline 25 & $30-40$ & Debitage & 1 \\
\hline 26 & $0-10$ & Debitage & 1 \\
\hline 74 & $0-10$ & Debitage & 1 \\
\hline 74 & $10-20$ & Debitage & 1 \\
\hline 74 & $30-40$ & Arrow point (Caracara) & 1 \\
\hline 75 & $0-10$ & Debitage & 1 \\
\hline 75 & $20-30$ & Debitage & 2 \\
\hline 79 & $0-10$ & Burned rock & 1 \\
\hline 79 & $20-30$ & Debitage & 1 \\
\hline 79 & $30-40$ & Debitage & 1 \\
\hline 80 & $40-50$ & Debitage & 1 \\
\hline 89 & $40-50$ & Debitage & 1 \\
\hline 92 & $10-20$ & Debitage & 1 \\
\hline 92 & $30-40$ & Debitage & 6 \\
\hline 92 & $40-50$ & Debitage & 1 \\
\hline 92 & $40-50$ & Glass & 1 \\
\hline \multicolumn{3}{|r|}{ Total } & 29 \\
\hline
\end{tabular}


Table 5-3. Cultural Material from Units at 41WB635 (FS 2b)

\begin{tabular}{|c|c|c|c|}
\hline Unit & Depth (cmbs) & Artifact Class & Count \\
\hline $\mathrm{A}$ & $30-40$ & Debitage & 3 \\
\hline $\mathrm{A}$ & $30-40$ & FCR & 1 \\
\hline $\mathrm{A}$ & $40-50$ & Burned rock & 1 \\
\hline $\mathrm{A}$ & $40-50$ & Debitage & 7 \\
\hline $\mathrm{A}$ & $50-60$ & Debitage & 5 \\
\hline $\mathrm{A}$ & $50-60$ & Metal & 1 \\
\hline $\mathrm{A}$ & $60-70$ & Debitage & 1 \\
\hline $\mathrm{B}$ & $40-50$ & Debitage & 3 \\
\hline $\mathrm{B}$ & $50-60$ & Debitage & 5 \\
\hline $\mathrm{B}$ & $50-60$ & Debitage & 2 \\
\hline $\mathrm{B}$ & $60-70$ & Debitage & 2 \\
\hline $\mathrm{C}$ & $30-40$ & Debitage & 1 \\
\hline $\mathrm{C}$ & $40-50$ & Debitage & 9 \\
\hline $\mathrm{C}$ & $50-60$ & Debitage & 2 \\
\hline $\mathrm{C}$ & $60-70$ & Debitage & 3 \\
\hline $\mathrm{C}$ & $70-80$ & Debitage & 1 \\
\hline $\mathrm{D}$ & $30-40$ & FCR & 1 \\
\hline $\mathrm{D}$ & $60-70$ & Debitage & 5 \\
\hline $\mathrm{E}$ & $30-40$ & Core & 1 \\
\hline$E$ & $30-40$ & Debitage & 7 \\
\hline $\mathrm{E}$ & $40-50$ & Debitage & 12 \\
\hline $\mathrm{E}$ & $40-50$ & Debitage & 1 \\
\hline $\mathrm{E}$ & $50-60$ & Debitage & 20 \\
\hline $\mathrm{E}$ & $50-60$ & Debitage & 1 \\
\hline $\mathrm{E}$ & $60-70$ & Debitage & 23 \\
\hline$E$ & $60-70$ & FCR & 1 \\
\hline $\mathrm{E}$ & $70-80$ & Debitage & 88 \\
\hline$E$ & $70-80$ & FCR & 1 \\
\hline $\mathrm{F}$ & $20-30$ & Lithic tool and cores & 1 \\
\hline $\mathrm{G}$ & $50-60$ & Debitage & 1 \\
\hline $\mathrm{G}$ & $90-100$ & Debitage & 1 \\
\hline \multicolumn{3}{|r|}{ Total } & 211 \\
\hline
\end{tabular}

Of the five units excavated in this area, TU E provided the most artifacts with a total of 155 specimens (Table 5-3). Of these, $152(98 \%)$ are pieces of debitage, one is a core, and two are fire-cracked rock (FCR) fragments. In terms of vertical distribution of the artifacts within Test Unit E, 5\% comes from Level 1 (30-40 cmbs), 8\% from Level 2 (40$50 \mathrm{cmbs}), 13 \%$ from Level $3(50-60 \mathrm{cmbs}), 15 \%$ from Level $4(60-70 \mathrm{cmbs})$, and $58 \%$ from Level 5 (70-80 cmbs). Please note that the upper $30 \mathrm{~cm}$ of matrix consisting of the plow zone was removed by shovel prior to the inception of hand excavation. The peak in artifacts present in Level 5 $(70-80 \mathrm{cmbs})$ was not reproduced in any of the test units and shovel tests surrounding TU E. Artifact counts in adjacent units and at a similar depth remained low in all other units suggesting that the peak in TU E may not be related to a buried cultural zone but instead may be the product of post-depositional agents.

It is also important to note that two additional FCR fragments were collected from TUs A and D. Small charcoal fragments were also recovered during both the Phase I survey and the testing phase but none of these specimens were associated with in situ features. No features were identified on the site. 
Table 5-4. Cultural Material from Auger Bores and Backhoe Trenches at 41WB635 (FS 2b)

\begin{tabular}{|c|c|c|c|}
\hline BHT/Auger & Depth (cmbs) & Artifact Class & Count \\
\hline BHT 10 & 0 & Debitage & 1 \\
\hline 20 & 0 & Lithic tools and cores & 1 \\
\hline BHT 10 & 0 & Lithic tools and cores & 1 \\
\hline 9 & $0-40$ & Debitage & 1 \\
\hline 16 & $0-40$ & Debitage & 1 \\
\hline 19 & $0-40$ & Debitage & 1 \\
\hline 21 & $0-40$ & Debitage & 1 \\
\hline 4 & $40-80$ & Debitage & 1 \\
\hline 8 & $40-80$ & Debitage & 1 \\
\hline 18 & $40-80$ & Debitage & 1 \\
\hline 1 & $80-120$ & Debitage & 1 \\
\hline 8 & $80-120$ & Debitage & 1 \\
\hline 9 & $80-120$ & Debitage & 1 \\
\hline 10 & $80-120$ & Debitage & 2 \\
\hline 12 & $80-120$ & Debitage & 1 \\
\hline 14 & $80-120$ & Debitage & 1 \\
\hline 25 & $80-120$ & Debitage & 1 \\
\hline 20 & $80-120$ & Debitage & 1 \\
\hline 21 & $80-120$ & Debitage & 1 \\
\hline \multicolumn{3}{|c}{} \\
\hline \multicolumn{3}{|c|}{} \\
\hline
\end{tabular}

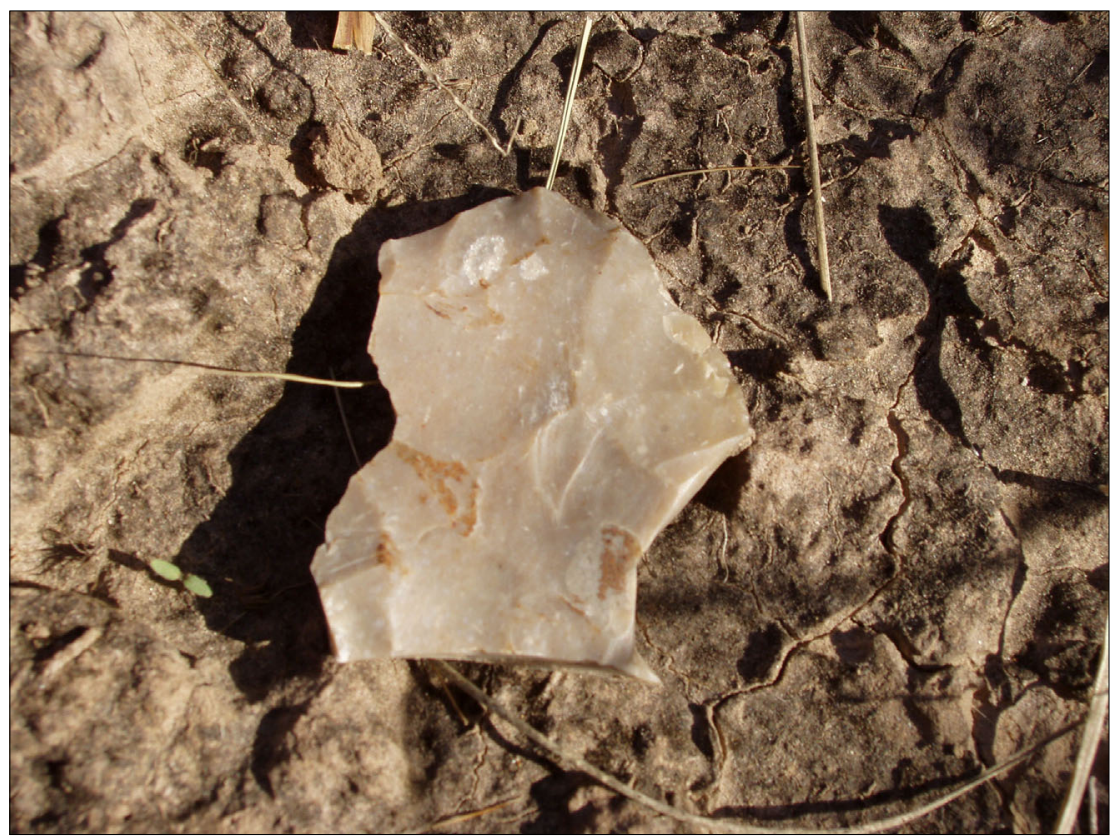

Figure 5-3. Biface from southernmost concentration on 41 WB635 (FS 2b). 
In order to compare the vertical distribution of cultural material for the entire site, the cultural material and snail shell from the 1-x-1-m units and the 50-x-50-cm units were combined. It is assumed that snail shell assemblages are a proxy indicator of stable floodplain surfaces. It is also assumed that stable surfaces would be more likely to be occupied by human populations for longer periods, resulting in archaeologically visible deposits. Therefore, we expect that a correspondence of peaks in snail shell counts and artifact counts will be a signature of stable floodplain surfaces once occupied by human populations.

In order to obtain a systematic and consistent data set, the data from the shovel tests, auger tests, and surface collections was not included in the analysis. The reason for not including the shovel test data in the analysis resides in the fact that snail shell was not collected during the Phase I survey and the difficulties in matching the size of the shovel test with the controlled hand excavation of units. The auger tests were excavated in $40-\mathrm{cm}$ levels as opposed to $10-\mathrm{cm}$ levels, therefore, the data from the auger tests was also excluded from the analysis. Finally, the first three levels $(0-30 \mathrm{cmbs})$ of the $50-\mathrm{x}-50-\mathrm{cm}$ units were excluded from the analysis because they consisted of the disturbed plow zone and this strata was removed before the excavation of the $1-x-1-m$ units. The analysis was only performed to Level 5 (70-80 $\mathrm{cmbs}$ ), the maximum depth of the 1-x-1-m units. Also, the data for the $50-\mathrm{x}-50-\mathrm{cm}$ units was multiplied by four to correlate with the data from the $1-x-1-m$ units.

A total of 210 artifacts was used for the analysis of vertical distribution of cultural material within 41WB635. An increase in artifact density was observed toward the deepest levels with a peak in Level $5(70-80 \mathrm{cmbs})$ that contained $43 \%$ of the artifacts. Again, however, this distribution is heavily skewed by the large number of pieces of debitage encountered in TU E. Table 5-5 presents the vertical distribution of artifacts per level. In contrast, the peak of snail shell distribution is between Level $3(50-60 \mathrm{cmbs})$ with $28 \%$ of the snail shell and Level $4(60-70 \mathrm{cmbs})$ containing $32 \%$ of the snail shell (Tables 5-6 and 5-7). The total adjusted count of snail shell used for the analysis was 104 .

As noted in the previous chapter, and as discussed in greater detail in Appendix D, magnetic sediment susceptibility (MSS) samples were collected from TU E at 41WB635. Figure 5-4 presents the results of that analysis (shown in red). The results have been standardized, such that the mean of the samples is plotted as 0 , and the distribution has a standard deviation of 1 . The standardization allows us to overlay the artifact counts for the 1-x-1-m units, which have also been standardized (blue), on the same graph. Focusing first on the MSS results, note that there is a dramatic increase in values between 70 and $80 \mathrm{cmbs}$. This increase is clearly suggestive of a buried surface at that depth. While the interpretation of the artifact patterning is hampered by the lack of data below $80 \mathrm{cmbs}$, note that the artifact distribution also shows a dramatic increase at $70-80 \mathrm{cmbs}$. The cooccurrence of peaks in both the MSS values and the artifact distribution is consistent with a buried occupation surface at this depth. However, the fact that the increase in artifacts at this level is only present in one unit suggests perhaps that it is not representative of a cultural depositional/living surface but rather is the product of post-depositional factors. Interestingly, the single diagnostic recovered from this site occurred at 30-40 cmbs, a depth that is not associated with a spike in either the MSS values or artifacts. This depth has the lowest overall MSS values and the lowest artifact counts (Figure 5-4). Along the same lines, the diagnostic Caracara point found was recovered from a context well above the increase in artifact density associated with Level 5 (70-80 cmbs). Likewise, at least the upper $30 \mathrm{~cm}$ of the site's deposits have been impacted and disturbed by root plowing and possibly chaining.

Table 5-5. Vertical Distribution of Artifacts from Units at 41WB635 (FS 2b)

\begin{tabular}{|c|c|c|c|}
\hline Level & Depth (cmbs) & Count & Percentage \\
\hline 1 & $30-40$ & 15 & 7 \\
\hline 2 & $40-50$ & 34 & 16 \\
\hline 3 & $50-60$ & 37 & 18 \\
\hline 4 & $60-70$ & 34 & 16 \\
\hline 5 & $70-80$ & 90 & 43 \\
\hline
\end{tabular}




\section{Site 41WB637 (Field Site 5)}

Site 41WB637 is an unknown temporal affiliation prehistoric debitage lithic scatter with light surface and subsurface deposits. The site is located on an upper alluvial terrace about $324 \mathrm{~m}$ east of the Rio Grande (Figure 5-5). The site is approximately $951 \mathrm{~m}^{2}$ (0.24 acres) in size. At the time of fieldwork, surface visibility at the site was poor (less than $5 \%$ ). A fence line and a ditch oriented north-south are located near the western edge of the site. The methods used to investigate the site included surface inspection as well as backhoe trenching $(\mathrm{n}=1)$, auger boring $(\mathrm{n}=24)$, and the excavation of a $50-\mathrm{x}-50-\mathrm{cm}$ test unit. Cultural material was encountered to a maximum depth of $110 \mathrm{cmbs}$. The cultural material observed at the site includes lithic debitage, one heat spall, and modern debris (Tables 5-8 and 5-9). The presence of modern debris such as plastic fragments and the fact that the site is an abandoned agricultural field that has been affected by pipeline installation activities suggests that the site has been greatly disturbed.

Given the limited amount of material present at the site, the data from the auger tests, the backhoe trench, and the 50-x$50-\mathrm{cm}$ unit were combined and the levels adjusted to match those used for the auger tests to provide a vertical distribution of material within the site. The prehistoric cultural material collected from the site consists entirely of debitage $(n=9$; Table 5-8). Of these, one artifact was recovered from the surface ( $8 \%$ ), $17 \%$ from $0-40 \mathrm{cmbs}, 42 \%$ from $40-80 \mathrm{cmbs}$, and $33 \%$ from $80-120 \mathrm{cmbs}$. A limited amount of snail shell was also collected from the site (Table 5-10). Of the 14 snail shells analyzed, $64 \%$ was recovered from $40-80 \mathrm{cmbs}$ and $36 \%$ from $80-120 \mathrm{cmbs}$. No features were identified on the site.
Table 5-6. Snail Shell from Units at Site 41WB635 (FS 2b)

\begin{tabular}{|c|c|c|}
\hline Unit & Depth (cmbs) & Count \\
\hline E & $30-40$ & 4 \\
\hline G & $30-40$ & 1 \\
\hline C & $40-50$ & 1 \\
\hline D & $40-50$ & 2 \\
\hline E & $40-50$ & 9 \\
\hline G & $40-50$ & 1 \\
\hline A & $50-60$ & 1 \\
\hline B & $50-60$ & 2 \\
\hline E & $50-60$ & 10 \\
\hline F & $50-60$ & 3 \\
\hline G & $50-60$ & 1 \\
\hline A & $60-70$ & 1 \\
\hline C & $60-70$ & 1 \\
\hline E & $60-70$ & 7 \\
\hline F & $60-70$ & 4 \\
\hline G & $60-70$ & 2 \\
\hline B & $70-80$ & 1 \\
\hline C & $70-80$ & 6 \\
\hline E & $70-80$ & 7 \\
\hline G & $70-80$ & 1 \\
\hline G & $80-90$ & 3 \\
\hline G & $100-110$ & 2 \\
\hline G & $110-120$ & 3 \\
\hline F & $120-130$ & 2 \\
\hline G & $120-130$ & 1 \\
\hline F & $130-140$ & 1 \\
\hline & $140-150$ & 2 \\
\hline & & 79 \\
\hline & & \\
\hline & & \\
\hline & & 10 \\
\hline
\end{tabular}

Table 5-7. Vertical Distribution of Adjusted Snail Shell Counts from Units at 41WB635 (FS 2b)

\begin{tabular}{|c|c|c|c|}
\hline Level & Depth (cmbs) & Count & Percentage \\
\hline 1 & $30-40$ & 8 & 8 \\
\hline 2 & $40-50$ & 16 & 15 \\
\hline 3 & $50-60$ & 29 & 28 \\
\hline 4 & $60-70$ & 33 & 32 \\
\hline 5 & $70-80$ & 18 & 17 \\
\hline
\end{tabular}




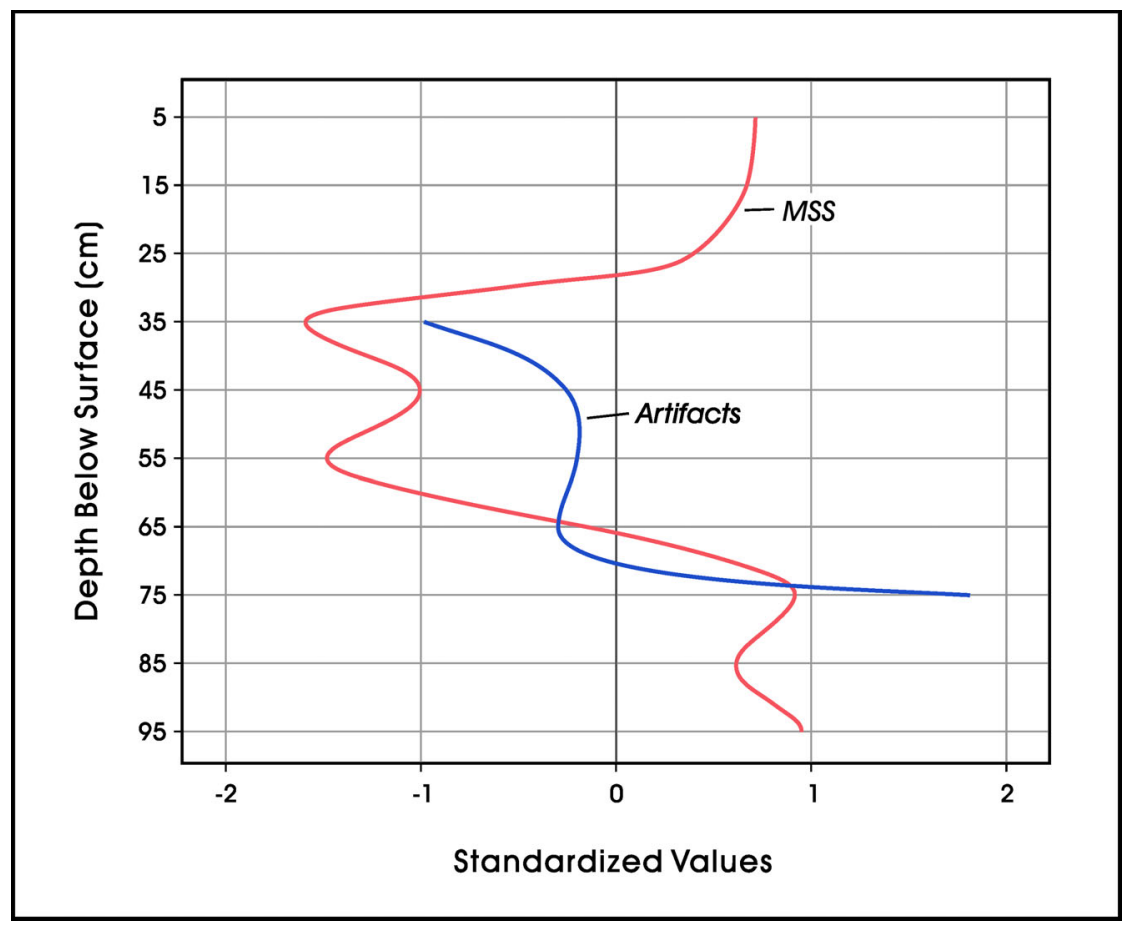

Figure 5-4. Standardized mass-specific soil susceptibility values for samples taken adjacent Test Unit E (red) overlaid on standardized artifact numbers from all test units (blue) for 41 WB635.

\section{Site 41WB638 (Field Site 6)}

Site 41WB638 consists of a highly disturbed secondary burial with no evidence of a burial pit or the presence of a cemetery site. The site is located in the southeast portion of the project area on an upper terrace about $434 \mathrm{~m}$ east of the Rio Grande (Figure 5-6). The site is approximately $366 \mathrm{~m}^{2}$ ( 0.09 acres) in size. Surface visibility was limited to less than 5\%. Three 1-x-1-m units were excavated from 40-150 $\mathrm{cm}$ below surface. In addition, five backhoe trenches were also excavated to search for additional cultural deposits or human remains in the vicinity of the original finds from BHT 6. One clearly human bone fragment, consisting of a proximal ulna, was found during the Phase I survey. None of the remaining 20 bone fragments found during the survey were identified as human; however, the sizes are consistent with human elements. The exact location and depth of where the bones were found is unknown, as the bones were recovered from the trench backdirt. However, it was estimated in the field that they came from between $80 \mathrm{~cm}$ and $100 \mathrm{~cm}$ below the ground surface. Sixteen additional pieces of bone were recovered from $120-130 \mathrm{cmbs}$ in one of the hand-excavated units (TU 2). Two of these pieces are possible human skull fragments. The rest of the Phase II bone was miscellaneous fragmented long bones that could not be identified with certainty as human. Their proximity to the skull fragments point to this possibility, but there are no diagnostic pieces from which a precise determination can be made. All of the bone fragments are heavily weathered and not articulated. Two pieces of lithic debitage were also recovered during the testing phase. One of these came from Level $2(50-60 \mathrm{cmbs})$ in TU 2 while the other was recovered from TU 1 at a depth of 110-120 cmbs (Level 8). A core was collected from the backdirt during the excavation of BHT 6-3. None of the lithic material was directly associated with the human remains. A moderate amount of snail shell was also collected from the test units (Table 5-11). The snail shells appear to be evenly distributed throughout the first six levels. The higher concentrations were found between Levels $7(60-70 \mathrm{cmbs})$ and $11(100-110 \mathrm{cmbs})$ and ranged from $9 \%$ to $16 \%$. A decrease in the concentration of snail shell $(4 \%)$ is observed in Level $12(110-120 \mathrm{cmbs})$. No snail shell was recovered from Levels 13 to 15 . Site 41WB638 has been disturbed by plowing activities and pipeline-related activities. No features were identified on the site. No disturbances were noted in any of the units or backhoe trenches excavated that would suggest the presence of an intact burial or a cemetery site. 


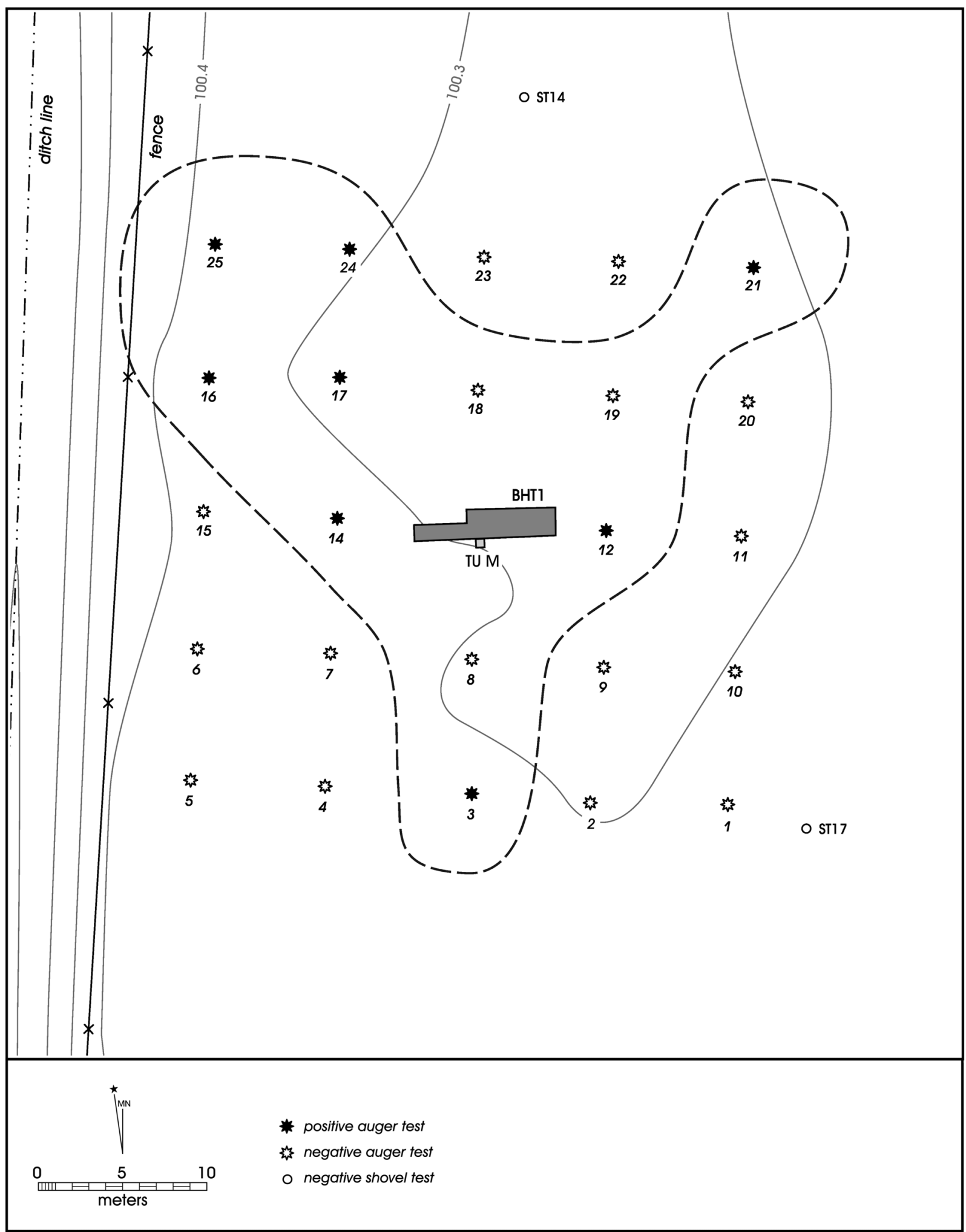

Figure 5-5. Map of site 41 WB637 (FS 5) showing locations of auger bores, shovel tests, the test unit, and the backhoe trench. 
Table 5-8. Cultural Material from Auger Bores and Backhoe Trenches at 41WB637 (FS 5)

\begin{tabular}{|c|c|c|c|}
\hline BHT/Auger & Depth (cmbs) & Artifact Class & Count \\
\hline BHT 1 & 0 & Debitage & 1 \\
\hline 3 & $0-40$ & Debitage & 1 \\
\hline 21 & $0-40$ & Debitage & 1 \\
\hline 3 & $0-40$ & Plastics & 1 \\
\hline 1 & $40-80$ & Debitage & 1 \\
\hline 17 & $40-80$ & Debitage & 1 \\
\hline 24 & $40-80$ & Debitage & 1 \\
\hline 14 & $80-120$ & Debitage & 1 \\
\hline 16 & $80-120$ & Debitage & 1 \\
\hline 25 & $80-120$ & Debitage & 1 \\
\hline \multicolumn{4}{|c}{} \\
\hline
\end{tabular}

Table 5-9. Cultural Material from Units at 41WB637 (FS 5)

\begin{tabular}{|c|c|c|c|}
\hline Unit & Depth (cmbs) & Artifact Class & Count \\
\hline $\mathrm{M}$ & $50-60$ & Debitage & 1 \\
\hline M & $60-70$ & Debitage & 1 \\
\hline $\mathrm{M}$ & $100-110$ & Debitage & 1 \\
\hline $\mathrm{M}$ & $100-110$ & Heat spall & 1 \\
\hline \multicolumn{3}{|r|}{ Total } & 4 \\
\hline
\end{tabular}

Table 5-10. Snail Shell from Units at 41WB637 (FS 5)

\begin{tabular}{|c|c|c|}
\hline Unit & Depth (cmbs) & Count \\
\hline $\mathrm{M}$ & $40-50$ & 1 \\
\hline $\mathrm{M}$ & $50-60$ & 1 \\
\hline $\mathrm{M}$ & $60-70$ & 3 \\
\hline $\mathrm{M}$ & $70-80$ & 4 \\
\hline $\bar{M}$ & $80-90$ & 0 \\
\hline $\mathrm{M}$ & $100-110$ & 3 \\
\hline $\mathrm{M}$ & $110-120$ & 2 \\
\hline \multicolumn{2}{|r|}{ Total } & 14 \\
\hline
\end{tabular}

\section{Site 41WB639 (Field Site 8b)}

Site 41WB639 is a Middle Archaic lithic scatter with a moderate density of lithic debitage and tools. The site is located on an upland terrace approximately $339 \mathrm{~m}$ southeast of the Rio Grande. It measures approximately $2,192 \mathrm{~m}^{2}(0.54$ acres; Figure 5-7). The area had been plowed and the ground was covered with tall grasses and sparse woody vegetation at the time of fieldwork (visibility less than 10\%). Work at the site encompassed surface inspection and the excavation of four backhoe trenches, 48 auger bores, and four test units. The cultural material encountered at the site includes one biface $(2 \%)$, three pieces of burned rock $(6 \%)$, one very small charcoal fragment ( $2 \%)$, two cores (4\%), 40 pieces of lithic debitage $(75 \%)$, three pieces of FCR $(6 \%)$, one miscellaneous lithic tool (2\%), a scraper (2\%), and a diagnostic Tortugas projectile point (2\%; Tables 5-12 and 5-13). A moderate number of snail shells was also recovered from the site (Table 5-14). No features were identified on the site. Figure 5-8 illustrates the Tortugas point found during the Phase II testing.

With the purpose of obtaining a description of the vertical distribution of artifacts and snail shell within the site, the data from the $50-\mathrm{x}-50-\mathrm{cm}$ units was combined into one data set. In order to obtain a systematic and consistent data set, the data from the shovel tests, auger tests, and surface collections was not included in the analysis. The reason for not including the shovel test data in the analysis resides in the fact that snail shell was not collected during the Phase I survey and the difficulties in matching the size of the shovel tests with the controlled hand excavation of units. The auger tests were excavated in $40-\mathrm{cm}$ levels as opposed to $10-\mathrm{cm}$ levels, therefore, the data from the auger tests was also excluded from the analysis. It is important to note that in the case of site 41WB639, the units were excavated in arbitrary $10-\mathrm{cm}$ levels starting at the surface and continuing to a depth of $150 \mathrm{~cm}$ below surface.

A total of 38 artifacts was used for the analysis (Table 5-15). No artifacts were collected from Levels 1, 3, 4, 6, 7, and 15 . The artifacts are distributed evenly with a slight increase per level from Level $2(10-20 \mathrm{cmbs})$ to Level 10 (90-100 cmbs). An increase in the number of artifacts occurs in Levels 11 and 12 (42\% and 21\%, respectively). The number of artifacts decreases again starting in Level 13 (11\%) and continues to decrease; no artifacts were recovered in Level 15 (140-150 cmbs). In the case of the distribution 


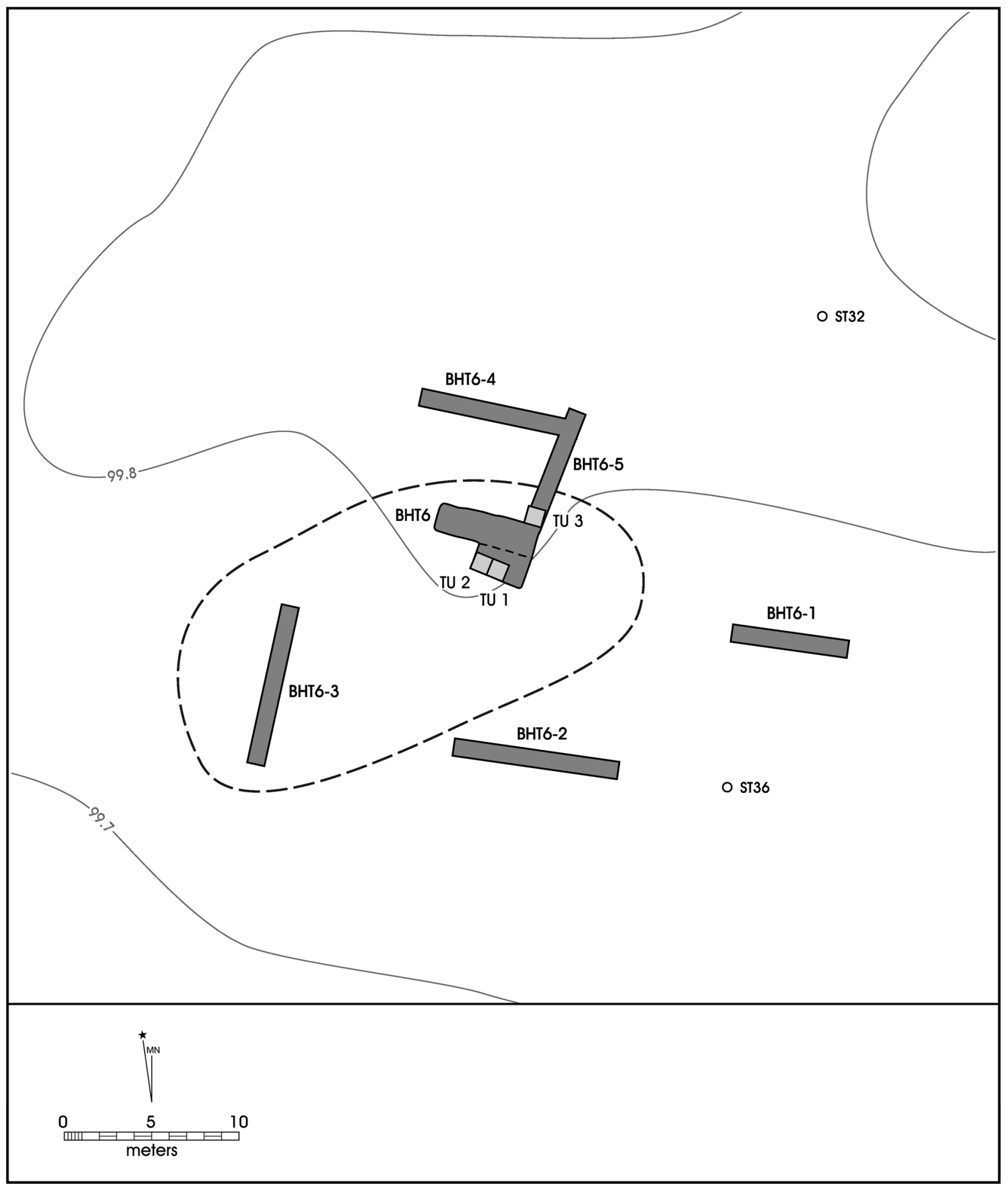

Figure 5-6. Map of site 41WB638 (FS 6) showing locations of test units and backhoe trenches. 
Table 5-11. Vertical Distribution of Snail Shell from Units at 41WB638 (FS 6)

\begin{tabular}{|c|c|c|c|}
\hline Level & Depth (cmbs) & Count & Percentage \\
\hline 1 & $0-10$ & 15 & 6 \\
\hline 2 & $10-20$ & 6 & 2 \\
\hline 3 & $20-30$ & 9 & 4 \\
\hline 4 & $30-40$ & 15 & 6 \\
\hline 5 & $40-50$ & 21 & 8 \\
\hline 6 & $50-60$ & 16 & 6 \\
\hline 7 & $60-70$ & 27 & 11 \\
\hline 8 & $70-80$ & 22 & 9 \\
\hline 9 & $80-90$ & 38 & 15 \\
\hline 10 & $90-100$ & 38 & 15 \\
\hline 11 & $100-110$ & 40 & 16 \\
\hline 12 & $110-120$ & 9 & 4 \\
\hline
\end{tabular}

of snail shell per level, the distribution occurs in a more even fashion across the levels (Table 5-16). A slight increase in the number of snail shells can be observed in Levels 3 and $4(7 \%$ and $10 \%$, respectively) and decreases again in the following levels. The highest percentage of snail shell occurs in Level $7(16 \%)$, but a decrease in the number of snail shells begins in the following level and continues through Level 15.

As noted in the previous chapter, and as discussed in Appendix D, magnetic sediment susceptibility samples were collected from both Field Site 8 and Field Site 9. These two sites were subsequently combined into $41 \mathrm{WB} 639$. Samples were collected in 5-cm intervals from TU H and TU J, both 50-x-50-cm units. Figure 5-9 presents the standardized results from these two units (red lines), along with the standardized distribution of artifacts (green) discussed previously for the two $50-\mathrm{x}-50-\mathrm{cm}$ units. Note that while there is certainly some variability in the two MSS sample curves, both seem to have a significant peak lower in the distribution (ca. 100-105 cmbs), a peak that is associated with a major spike in the number of artifacts at 100-110 cmbs. While a lower surface is also suggested by the MSS curve for TU $\mathrm{H}$ at about $130 \mathrm{cmbs}$, the co-occurrence of the artifact peak with higher magnetic susceptibility values is clearly consistent with a buried surface that has associated cultural material. It is also important to note that a lithic scatter was found in a cluster starting at $105 \mathrm{cmbs}$ in TU J. This lithic cluster continued down to about $113 \mathrm{cmbs}$. The Tortugas projectile point was also found within the lithic cluster, at about $111 \mathrm{cmbs}$. Even though no soil stains or features were found, it was evident in the field that the cluster of lithic artifacts consisted of a buried surface.

\section{Site 41WB640 (Field Site 11)}

Site 41 WB640 is a prehistoric lithic scatter of unknown temporal affiliation consisting of light surface and subsurface deposits. The site is located in the southernmost part of the project area roughly $514 \mathrm{~m}$ southeast of the Rio Grande in an upland alluvial terrace (Figure 5-10). The area consists of an abandoned field that has been cleared of vegetation and has been systematically and repeatedly plowed. The site is approximately $591 \mathrm{~m}^{2}(0.15$ acres $)$ in size. Surface visibility was roughly $15 \%$. The methodology used to investigate this site included surface inspection, backhoe trenching $(n=1)$, auger testing $(n=24)$ and the manual excavation of one $50-x-50-\mathrm{cm}$ unit. The cultural material encountered at the site includes only five pieces of lithic debitage collected from the auger bores, one core from TU L (Level 3, 20-30 cmbs), and small tooth fragments from AU 7 (80-120 cmbs; Tables 5-17 and 5-18). Identification of the tooth fragments was not possible because the pieces are too fragmented and small.

In order to provide a vertical distribution of artifacts and snail shell within 41WB640, the data from the auger tests and the 50-x-50-m unit was combined and the levels adjusted to match those used for the auger tests. Of the six artifacts recovered from the site, one (17\%) was recovered from the surface, three (50\%) from Level $2(40-80 \mathrm{cmbs})$, and two (33\%) from Level 3 (80-120 cmbs). In the case of snail shell, it all came from the $50-\mathrm{x}-50$-cm unit. Its distribution was at follows: $11 \%(\mathrm{n}=1)$ from Level $1(0-40 \mathrm{cmbs}), 56 \%$ $(n=5)$ from Level $2(40-80 \mathrm{cmbs})$, and $33 \%(n=3)$ from Level $3(80-120 \mathrm{cmbs})$. No features were identified on site. 


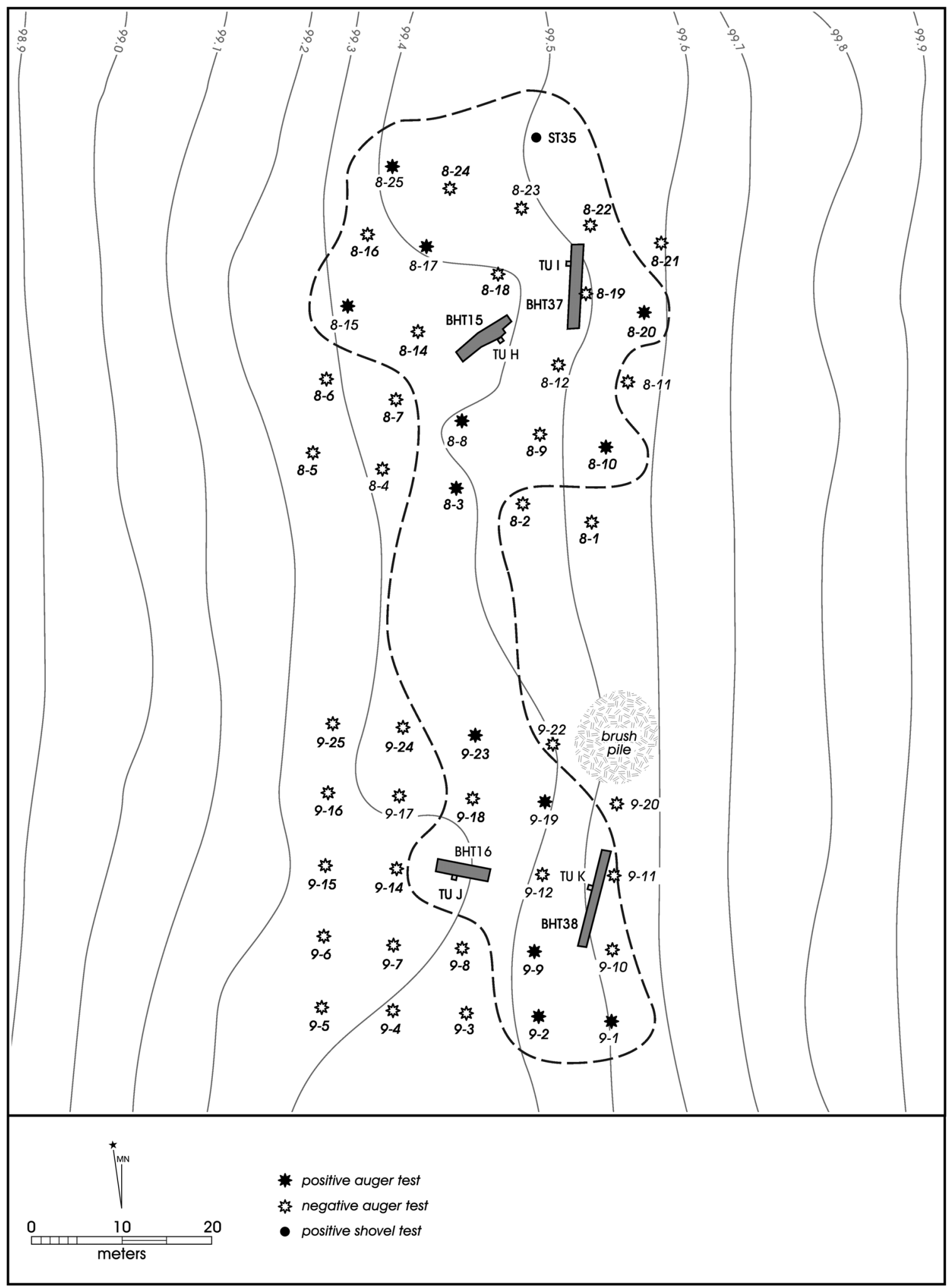

Figure 5-7. Map of site 41WB639 (FS 8b) showing locations of auger bores, 50-x-50-cm units, shovel tests, and backhoe trenches. 
Table 5-12. Cultural Material from Auger Bores and Backhoe Trenches at 41WB639 (FS 8b)

\begin{tabular}{|c|c|c|c|}
\hline BHT/Auger & Depth (cmbs) & Artifact Class & Count \\
\hline BHT 15 & 0 & Debitage & 1 \\
\hline BHT 15 & 0 & Debitage & 1 \\
\hline BHT 16 & 0 & Debitage & 1 \\
\hline 19 & $0-40$ & FCR & 1 \\
\hline 23 & $40-80$ & Debitage & 1 \\
\hline 3 & $80-120$ & Debitage & 1 \\
\hline 8 & $80-120$ & Debitage & 1 \\
\hline 10 & $80-120$ & Debitage & 1 \\
\hline 17 & $80-120$ & Debitage & 1 \\
\hline 20 & $80-120$ & Debitage & 1 \\
\hline 25 & $80-120$ & Debitage & 1 \\
\hline 1 & $80-120$ & Debitage & 1 \\
\hline 2 & $80-120$ & Debitage & 1 \\
\hline 15 & $80-120$ & Lithic tools and cores & 1 \\
\hline 9 & $80-120$ & Scraper & 1 \\
\hline \multicolumn{3}{|c}{} \\
\hline
\end{tabular}

Table 5-13. Cultural Material from Units at 41WB639 (FS 8b)

\begin{tabular}{|c|c|c|c|}
\hline Unit & Depth (cmbs) & Artifact Class & Count \\
\hline H & $100-110$ & Burned rock & 2 \\
\hline H & $110-120$ & Debitage & 2 \\
\hline H & $120-130$ & Biface & 1 \\
\hline H & $120-130$ & Debitage & 3 \\
\hline H & $130-140$ & Debitage & 1 \\
\hline H & $70-80$ & Debitage & 1 \\
\hline I & $110-120$ & Debitage & 1 \\
\hline I & $90-100$ & Debitage & 1 \\
\hline J & $100-110$ & Core & 1 \\
\hline J & $100-110$ & Debitage & 5 \\
\hline J & $100-110$ & Debitage & 1 \\
\hline J & $100-110$ & FCR & 2 \\
\hline J & $110-120$ & Core & 1 \\
\hline J & $110-120$ & Debitage & 3 \\
\hline J & $110-120$ & Tortugas point & 1 \\
\hline J & $20-30$ & Burned rock & 1 \\
\hline J & $40-50$ & Debitage & 1 \\
\hline K & $100-110$ & Debitage & 5 \\
\hline K & $70-80$ & Debitage & 1 \\
\hline K & $80-90$ & Debitage & 1 \\
\hline K & $90-100$ & Debitage & 2 \\
\hline & & & 37 \\
\hline
\end{tabular}


Table 5-14. Snail Shell from Units at 41WB639 (FS 8b)

\begin{tabular}{|c|c|c|}
\hline Unit & Depth (cmbs) & Count \\
\hline $\mathrm{J}$ & $0-10$ & 1 \\
\hline I & $10-20$ & 1 \\
\hline $\mathrm{J}$ & $10-20$ & 1 \\
\hline$\overline{\mathrm{H}}$ & $20-30$ & 2 \\
\hline $\bar{I}$ & $20-30$ & 2 \\
\hline $\mathrm{H}$ & $30-40$ & 2 \\
\hline I & $30-40$ & 3 \\
\hline $\bar{K}$ & $30-40$ & 1 \\
\hline $\mathrm{H}$ & $40-50$ & 1 \\
\hline $\mathrm{J}$ & $40-50$ & 1 \\
\hline$\overline{\mathrm{H}}$ & $50-60$ & 1 \\
\hline I & $50-60$ & 2 \\
\hline $\mathrm{H}$ & $60-70$ & 1 \\
\hline I & $60-70$ & 3 \\
\hline $\bar{K}$ & $60-70$ & 1 \\
\hline $\mathrm{J}$ & $60-70$ & 2 \\
\hline $\mathrm{J}$ & $60-70$ & 2 \\
\hline $\mathrm{I}$ & $70-80$ & 3 \\
\hline $\mathrm{K}$ & $70-80$ & 2 \\
\hline I & $80-90$ & 1 \\
\hline $\mathrm{J}$ & $80-90$ & 1 \\
\hline$\overline{\mathrm{K}}$ & $80-90$ & 2 \\
\hline $\mathrm{H}$ & $90-100$ & 1 \\
\hline $\mathrm{J}$ & $90-100$ & 2 \\
\hline $\bar{K}$ & $90-100$ & 3 \\
\hline $\mathrm{I}$ & $100-110$ & 1 \\
\hline $\mathrm{J}$ & $100-110$ & 1 \\
\hline $\mathrm{K}$ & $100-110$ & 1 \\
\hline $\mathrm{H}$ & $110-120$ & 1 \\
\hline $\mathrm{J}$ & $110-120$ & 2 \\
\hline $\mathrm{H}$ & $120-130$ & 2 \\
\hline I & $120-130$ & 1 \\
\hline $\mathrm{I}$ & $130-140$ & 1 \\
\hline $\mathrm{K}$ & $130-140$ & 1 \\
\hline I & $140-150$ & 1 \\
\hline $\mathrm{K}$ & $140-150$ & 2 \\
\hline $\mathrm{J}$ & $140-150$ & 1 \\
\hline \multicolumn{2}{|r|}{ Total } & 57 \\
\hline
\end{tabular}

\section{Isolated Finds}

After completion of the Phase II testing, and based on the site definition used for the purposes of this study, it was determined that Field Site 10 represented an isolated find (IF-10). The 11 isolated finds defined by the Phase I survey are discussed in Chapter 3 of this report; however, it is important to note that two of these isolated finds were incorporated as part of sites $41 \mathrm{WB} 635$ and 41WB639. IF-10 was originally defined in BHT 26 based on an early stage biface found at $75 \mathrm{cmbs}$.

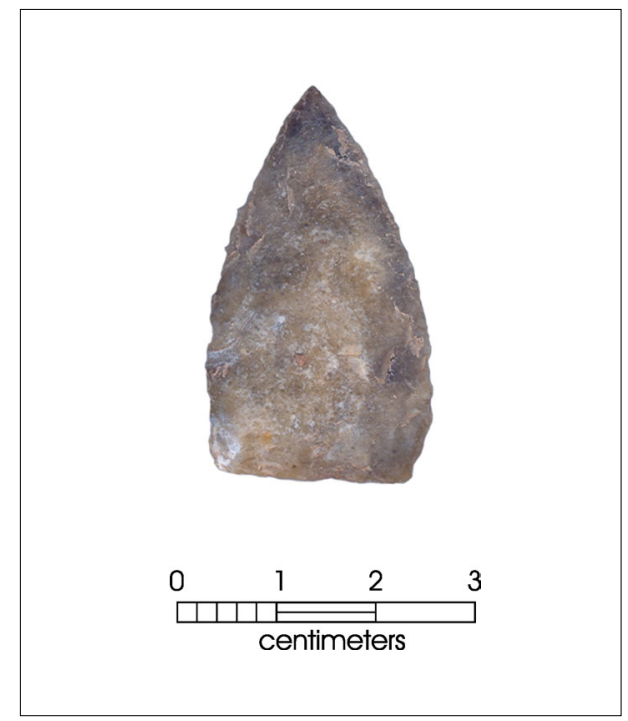

Figure 5-8. Tortugas point recovered during Phase II testing at site 41 WB639 (FS 8b).

The Phase II testing efforts included the mechanical excavation of auger bores and one $50-x-50-\mathrm{cm}$ unit. Only one additional piece of lithic debitage was found as well as two modern glass fragments. No cultural material or features were observed in the hand-excavated unit.

\section{Discussion of Results}

This section of the report presents a general description of the vertical distribution of cultural materials and snail shells across the entire project area. First, the vertical distribution by site is described for each of the sites defined by the Phase II testing. Subsequently, a general vertical description for the entire project area is presented.

Site $41 \mathrm{WB} 635$ is a Late Prehistoric site with a surface and subsurface distribution of lithic debitage and lithic tools. An increase in the number of artifacts occurs from the upper to the lower levels. The majority of the artifacts $(42 \%)$ were recovered from $70-80 \mathrm{cmbs}$. Artifacts were also found at deeper levels (100-110 cmbs) in the 50-x-50-cm units. In the case of snail shell, the increase also occurs between Level $6(50-60 \mathrm{cmbs})$ and Level 7 (60-70 cmbs). The MSS results show a dramatic increase in values at $70-80 \mathrm{cmbs}$. This increase is clearly suggestive of a buried surface at this depth. Likewise, the artifact distribution also shows a dramatic increase at 70-80 cmbs. Unfortunately, the increase in artifacts is present in a single unit suggesting that it is not 
Table 5-15. Vertical Distribution of Artifacts from Units at 41WB639 (FS 8b)

\begin{tabular}{|c|c|c|c|}
\hline Level & Depth (cmbs) & Count & Percentage \\
\hline 1 & $0-10$ & 0 & 0 \\
\hline 2 & $10-20$ & 1 & 3 \\
\hline 3 & $20-30$ & 0 & 0 \\
\hline 4 & $30-40$ & 0 & 0 \\
\hline 5 & $40-50$ & 1 & 3 \\
\hline 6 & $50-60$ & 0 & 0 \\
\hline 7 & $60-70$ & 0 & 0 \\
\hline 8 & $70-80$ & 2 & 5 \\
\hline 9 & $80-90$ & 1 & 3 \\
\hline 10 & $90-100$ & 3 & 8 \\
\hline 11 & $100-110$ & 16 & 42 \\
\hline 12 & $110-120$ & 8 & 21 \\
\hline 13 & $120-130$ & 4 & 11 \\
\hline 14 & $130-140$ & 2 & 5 \\
\hline 15 & $140-150$ & 0 & 0 \\
\hline
\end{tabular}

Table 5-16. Vertical Distribution of Snail Shell from Units at $41 \mathrm{WB} 639$ (FS 8b)

\begin{tabular}{|c|c|c|c|}
\hline Level & Depth (cmbs) & Count & Percentage \\
\hline 1 & $0-10$ & 1 & 2 \\
\hline 2 & $10-20$ & 2 & 4 \\
\hline 3 & $20-30$ & 4 & 7 \\
\hline 4 & $30-40$ & 6 & 10 \\
\hline 5 & $40-50$ & 2 & 4 \\
\hline 6 & $50-60$ & 3 & 5 \\
\hline 7 & $60-70$ & 9 & 16 \\
\hline 8 & $70-80$ & 5 & 9 \\
\hline 9 & $80-90$ & 4 & 7 \\
\hline 10 & $90-100$ & 6 & 10 \\
\hline 11 & $100-110$ & 3 & 5 \\
\hline 12 & $110-120$ & 3 & 5 \\
\hline 13 & $120-130$ & 3 & 5 \\
\hline 14 & $130-140$ & 2 & 4 \\
\hline 15 & $140-150$ & 4 & 7 \\
\hline
\end{tabular}

representative of a cultural depositional zone. The cooccurrence of peaks in both the MSS values and the artifact distribution is consistent with a buried surface at this depth and may signal a cultural occupation surface, although the factors leading to the increase in artifact density with depth is unclear. The Caracara point recovered from this site occurred at 30-40 cmbs, a depth that is not associated with a spike in either MSS values or artifact density.
Site $41 \mathrm{WB} 637$ is a prehistoric lithic scatter of unknown temporal affiliation consisting mostly of lithic debitage. An increase in the number of artifacts occurs from the surface to Level 2 (40-80 cmbs) and decreases in Level 3 (80-120 cmbs). The majority of the artifacts $(42 \%)$ were found in Levels 2 and 3 . In the case of snail shell, it only occurs in Levels 2 and 3 with the majority of it in Level 2 (64\%). The increase in the number of snail shells is directly associated with the increase in the number of artifacts. The pattern is suggestive of a buried stable floodplain setting.

Site $41 \mathrm{WB} 638$ is a disturbed secondary prehistoric burial with limited amounts of cultural material and human remains. Based on the data available, the distribution of snail shell increases in the deeper levels with the higher concentrations (15-16\%) between Level 9 (80-90 cmbs) and Level 11 (100$110 \mathrm{cmbs})$. The increase in the number of snail shells occurs at about the same depth as the human remains found at the site. As in the case of 41WB637, the co-occurrence of these materials is suggestive of a buried stable floodplain setting.

Site 41WB639 is a Middle Archaic prehistoric lithic scatter consisting of a low density of lithic debitage and tools. The higher concentration of artifacts (42\% and $21 \%)$ occurs in Levels 11 (100-110 cmbs) and Level 12 (110-120 cmbs). In the case of snail shell, it is more evenly distributed across the levels. The peak in its distribution (16\%) occurs in Level 7 (60-70 cmbs). In addition, the MSS sample curves seem to have a significant peak lower in the distribution (ca. 100$105 \mathrm{cmbs}$ ), a peak that is associated with a major spike in the number of artifacts at $100-110 \mathrm{cmbs}$. This spike is associated with the cluster of lithic artifacts observed during fieldwork. The co-occurrence of the artifact peak with higher magnetic susceptibility values is clearly consistent with a buried surface that has associated cultural material. Also, the Tortugas projectile point was recovered at about $111 \mathrm{cmbs}$.

Site $41 \mathrm{WB} 640$ is a prehistoric site with an unknown temporal affiliation and consists of a light scatter of lithic debitage. The peak of artifact distribution (50\%) occurs in Level 2 (40-80 cmbs), decreasing slightly (33\%) in Level 3 $(80-120 \mathrm{cmbs})$. The distribution of snail shell is directly associated with the distribution of artifacts. The peak in snail shell also occurs in Level 2 (56\%) and Level 3 (33\%).

In general terms, a brief description of the artifact distribution can be made for the project area as a whole. Based on the data available, artifacts are mainly distributed between 60 $\mathrm{cm}$ and $80 \mathrm{~cm}$ below surface, and the recovery of a Caracara 


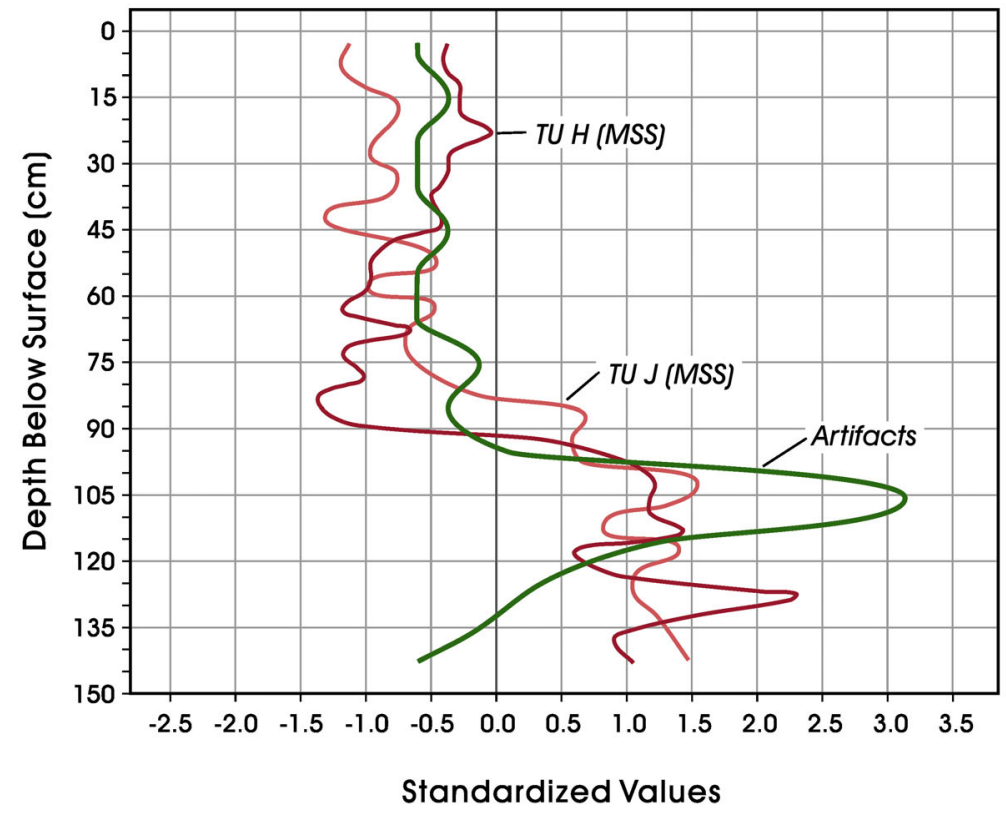

Figure 5-9. Standardized mass-specific soil susceptibility values for samples taken from Test Unit $H$ and Test Unit J (red) overlaid on standardized artifact numbers (green) for $41 \mathrm{WB} 639$.

point suggests the presence of a Late Prehistoric stable surface at this depth. It is important to note, however, that this possible shallow stable surface has likely been impacted by plowing and/or vegetation clearance. Another stable surface, probably dating to the Middle Archaic, appears to be present between $90 \mathrm{~cm}$ and $110 \mathrm{~cm}$ below surface. This possibility is supported by the fact that snail shell distributions in several sites (i.e., 41WB637, 41WB638, and 41WB639) appear to be directly correlated with artifact distributions. In all, the higher the distribution of cultural material, the higher the concentration of snail shell. It is important to note that the vertical distribution of artifacts appears to be very similar throughout the entire project area.

\section{Summary and Recommendations}

On December 13-17, 2004, the Center for Archaeological Research (CAR) of The University of Texas at San Antonio conducted Phase I archaeological work on a 160-acre property near Laredo, Webb County, Texas. A total of 11 field sites was documented by these investigations. Of these, eight sites were recommended for Phase II testing. No additional investigations were recommended at one site
(41WB634), although its National Register of Historic Places (NRHP) and State Archeological Landmark (SAL) eligibility remained unknown, because according to the construction plans and information provided by MACTEC, the site falls outside of the facility footprint and therefore will not be impacted by the proposed construction. Also, no additional work was recommended by CAR at $41 \mathrm{WB} 636$ and Field Site 4.

The Phase II investigations were conducted by CAR on March 1-5, March 9-18, and April 2-5, 2005, for NRHP eligibility testing and formal SAL designation. The Phase II investigations included the hand excavation of test units as well as mechanical auger testing and backhoe trenching. A total of five sites was defined by the Phase II testing and the compilation of all available materials. Originally defined Field Site 4 was combined with Field Sites 2 and 7 into site 41WB635 (FS 2b) based on their proximity to each other. A similar situation occurred with Field Sites 8 and 9; these were combined into site $41 \mathrm{WB} 639$ (FS 8b). In all, a total of seven sites was reported to the Texas Archeological Research Laboratory and received trinomial site designations. One isolated find (IF-10) consisting of a biface and one fragment 


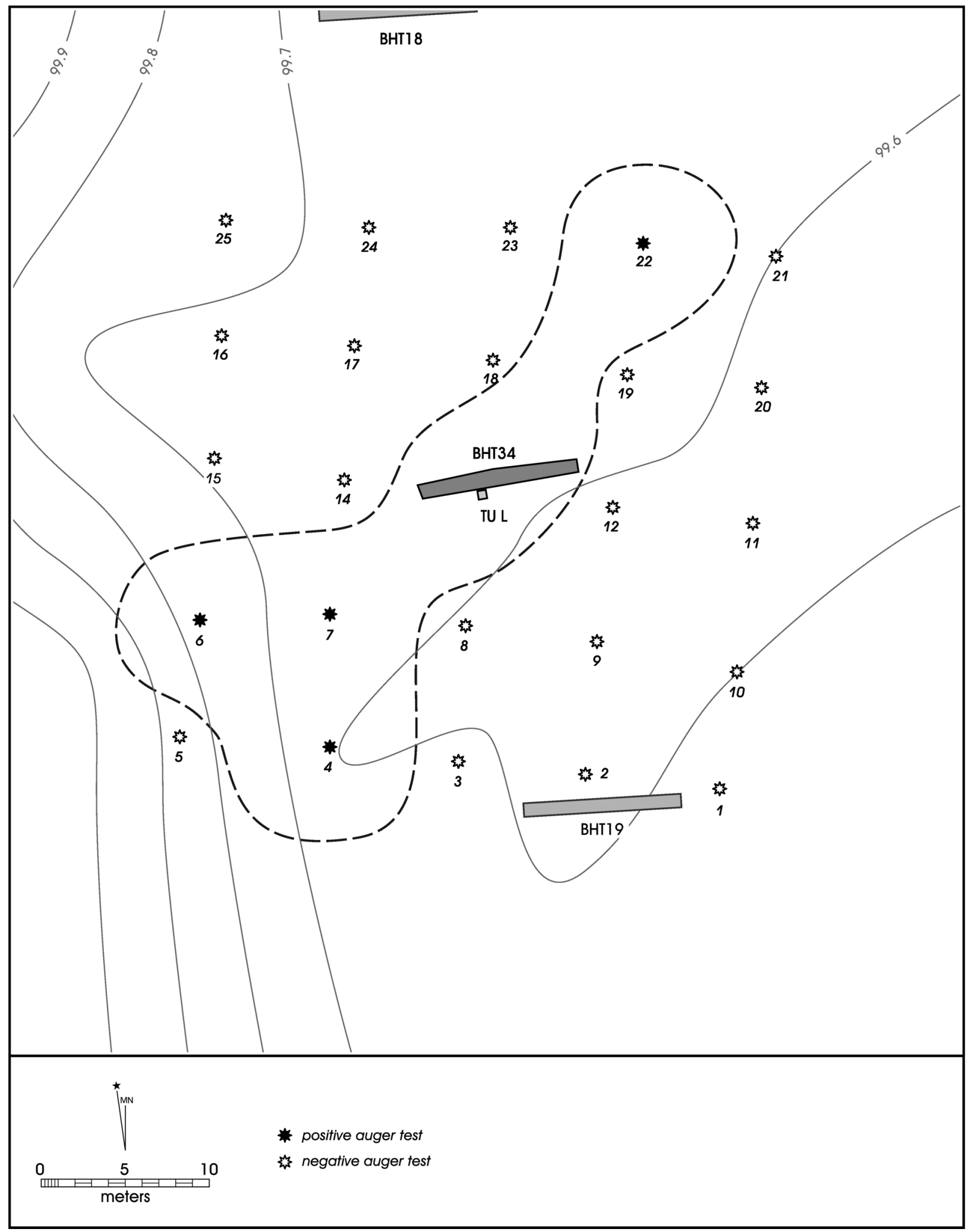

Figure 5-10. Map of site 41 WB640 (FS 11) showing locations of backhoe trenches, auger bores, and the test unit (TU L). 
Table 5-17. Cultural Material from Auger Bores, Backhoe Trenches and Units at 41WB640 (FS 11)

\begin{tabular}{|c|c|c|c|}
\hline BHT/Auger/Unit & Depth (cmbs) & Artifact Class & Count \\
\hline BHT 34 & 0 & Debitage & 1 \\
\hline $\mathrm{AU} 4$ & $40-80$ & Debitage & 1 \\
\hline AU 22 & $40-80$ & Debitage & 1 \\
\hline Unit L & $50-60$ & Core & \\
\hline AU 7 & $80-120$ & Bone & 0 \\
\hline AU 6 & $80-120$ & Debitage & 1 \\
\hline AU 7 & $80-120$ & Debitage & 1 \\
\hline \multicolumn{3}{|r|}{ Total } & 5 \\
\hline
\end{tabular}

Table 5-18. Snail Shell from Units at 41WB640 (FS 11)

\begin{tabular}{|c|c|c|}
\hline Unit & Depth (cmbs) & Count \\
\hline L & $20-30$ & 1 \\
\hline L & $40-50$ & 2 \\
\hline L & $50-60$ & 3 \\
\hline L & $70-80$ & 0 \\
\hline L & $80-90$ & 1 \\
\hline L & $90-100$ & 0 \\
\hline L & $100-110$ & 2 \\
\hline L & $110-120$ & 0 \\
\hline \multicolumn{2}{r|}{ Total } & 9 \\
\hline
\end{tabular}

of lithic debitage were also documented during the Phase II testing. In addition, 11 isolated finds were documented in shovel tests in non-site areas during the Phase I survey. Two of these finds were later included in sites. The locations of all the sites and isolated finds documented during the investigations are presented in Figure 5-11 (not published).

Site 41WB635 is a Late Prehistoric site with surface and subsurface distributions of lithic debitage and lithic tools. The site measures approximately $9,777 \mathrm{~m}^{2}$. The presence of historic and modern artifacts on the surface and in subsurface deposits suggests some disturbances due to erosion, land clearing and plowing. No features were identified on the site. Even though a diagnostic Caracara point was collected from the site, it occurred at $30-40 \mathrm{cmbs}$, a depth that has one of the lowest overall MSS values and is not associated with a spike in artifacts that is notable at a depth of 70-80 cmbs, at least within TU E. Given that the spike in artifact counts is only present within TU E, it is our interpretation that it may be the product of post-depositional factors rather than being representative of a cultural depositional zone. The presence of an increase in MSS values at $70-80 \mathrm{cmbs}$ does represent an increase in the organic content of the deposits but whether this increase derives from human or natural enrichment is not clear. Based on the fact that the high count in artifacts is present in a single unit, and other units contain low numbers of artifacts and no features have been identified on site, it is recommended that the site is not eligible for NRHP nomination or formal SAL designation.

Site $41 \mathrm{WB} 637$ is a prehistoric lithic scatter of unknown temporal affiliation with light surface and subsurface deposits. The site is approximately $951 \mathrm{~m}^{2}$. The presence of modern debris and the fact that the site has been affected by pipeline installation and agricultural activities suggests that the site is greatly disturbed. The site yielded limited amounts of cultural materials. Based on the lack of integrity of this site, in combination with its low artifact density and unknown temporal affiliation, it is the opinion of CAR that the Phase II investigations have exhausted its research potential. It is recommended that the site is not eligible for NRHP nomination or for SAL designation.

Site 41WB638 is a highly disturbed secondary burial with no evidence of burial pits or the presence of a cemetery. The bone fragments are heavily weathered and not articulated. The site is approximately $366 \mathrm{~m}^{2}$. Two fragments 
of lithic debitage and a core were collected from the site, but these were not directly associated with the human remains. Site observations indicate that the site has been affected by pipeline installation and agricultural activities suggesting that the site is greatly disturbed. Likewise, the site yielded only limited amounts of cultural materials. Based on the lack of integrity of this site, it is the opinion of CAR that the Phase II investigations have exhausted its research potential. It is CAR's recommendation that the site is not eligible for NRHP nomination or for SAL designation.

Site 41WB639 contains a Middle Archaic prehistoric component with a moderate density of lithic debitage and tools. The Middle Archaic component is buried at a depth of $110-130 \mathrm{cmbs}$. The site is approximately $2,192 \mathrm{~m}^{2}$. The presence of some fire-cracked rock and a small piece of charcoal may suggest the presence of buried features, even though no features were identified on the site during the Phase II excavations. Likewise, the site yielded two cores, one biface, one miscellaneous lithic tool, a scraper, and a Tortugas point. Also, the artifact peak and associated higher magnetic susceptibility values is clearly consistent with a buried surface that has associated cultural material. In summary, the site contains a buried Middle Archaic component that could yield information on a regional level. Based on the findings within the proposed project area, the site is interpreted as eligible for NRHP listing under Criterion D. Likewise, the site is interpreted as having potential to contribute to a better understanding of the prehistory of Texas and is therefore also eligible for SAL designation based on Criterion 1.

Site 41 WB640 is a prehistoric lithic scatter of unknown temporal affiliation with light surface and subsurface deposits. The site is approximately $591 \mathrm{~m}^{2}$. Field observations suggest that the site has been affected by agricultural activities and has been significantly disturbed. The site yielded limited amounts of cultural materials. Based on the lack of integrity of this site, in combination with its low artifact density that cannot be assigned to a known time period, it is the opinion of CAR that the Phase II investigations have exhausted its research potential. The site is interpreted as not eligible for NRHP listing or for SAL designation.

In summary, the Phase I and Phase II work conducted within the project area revealed two archaeological sites where additional archaeological efforts may be necessary in the future, if and when construction plans are altered and the archaeological components on these sites are to come under impact. Site 41WB634 is a moderate-density prehistoric site with cultural materials buried rather shallowly between 10 $\mathrm{cm}$ and $50 \mathrm{~cm}$ below surface. The site was documented during the Phase I survey, but because it falls outside of the facility footprint, no further work is proposed within its boundaries. Therefore, the NRHP and SAL eligibility of the site remains unknown. However, if the facility footprint is moved to the north, such that the site is included within the footprint or if additional impacts are to occur outside of the proposed footprint in the vicinity of the site, CAR recommends that the site be tested for NRHP and SAL eligibility. The second site, 41WB639, contains a Middle Archaic component buried between $110 \mathrm{~cm}$ and $130 \mathrm{~cm}$ below surface. Although the site is within the facility footprint, its location is in an area projected to be left as an open courtyard between nearby buildings. Subsurface disturbances are not anticipated to reach below two feet, or roughly $60 \mathrm{~cm}$. With this in mind, CAR recommends that the project be allowed to proceed with the stipulation that construction impacts within the boundaries of 41WB639 extend no deeper than the upper $60-70 \mathrm{~cm}$ below surface. However, if the proposed construction plan or the depth of the impacts is extended beyond $70 \mathrm{~cm}$, additional investigations and data recovery at the site are recommended to mitigate the impacts to the site before the project proceeds.

Following the submission of the draft final report to the Texas Historical Commission, reviewer Debra Beene contacted CAR and discussed the possibility that a buried stable floodplain surface may be present across the project area, buried between $80 \mathrm{~cm}$ and $120 \mathrm{~cm}$ below surface. She suggested that while evidence of this buried surface appears to be present in much of the work conducted by CAR, it is particularly well represented at sites 41WB637, 41WB638, and 41WB639. In addition, in her assessment, with the exception of 41WB639, the buried deposits have not been sufficiently well investigated to determine their NRHP/SAL eligibility status; therefore, significant subsurface disturbances above these sites may jeopardize potentially NRHP/SAL eligible deposits. CAR approached MACTEC and The GEO Group regarding the types and depths of impacts above these three sites. The GEO Group, as reproduced in the letter in Appendix E, indicated that subsurface impacts would be very shallow above these sites, since work will be limited to the general landscaping of the project area (i.e., planting of grass cover) and therefore will not impact the potentially NRHP/SAL eligible deposits. 
In summary, in the opinion of the Texas Historical Commission reviewer, the eligibility of the deeper deposits at sites 41WB637 and 41WB638 has not been fully assessed. The eligibility of site 41WB634 has not been determined and the deeper deposits at $41 \mathrm{WB} 639$ are NRHP/SAL eligible. Site 41WB634 falls outside of the facility footprint and will not be impacted by construction. The types of impacts at sites 41WB637, 41WB638 and 41WB639 will be limited to foot traffic and landscaping associated with the establishment of grass cover $(0-30 \mathrm{cmbs})$. Given these parameters, it is the suggestion of the CAR staff that the archaeological deposits will suffer no adverse effects from the planned construction. However, if the parameters of the construction project are modified (i.e., footprint relocation) so that resulting activities will impact either the limits of $41 \mathrm{WB} 634$ or will penetrate below the plow zone $(30 \mathrm{cmbs})$ within the boundaries of sites 41WB637, 41WB638 and 41WB639, CAR recommends the undertaking of archaeological testing to determine the NRHP/SAL eligibility of the buried deposits at 41WB637 and 41WB638 and the impact of the activities on the NRHP/SAL eligible deposits of $41 \mathrm{WB} 639$. 


\section{References Cited}

Barnes, V. G.

1976 Geologic Atlas of Texas, Laredo Sheet. Bureau of Economic Geology, University of Texas at Austin.

Birkeland, P. W.

1984 Soils and Geomorphology. Oxford University Press, New York.

Black, S. L.

1989a South Texas Plains. In From the Gulf to the Rio Grande: Human Adaptation in Central, South, and Lower Pecos Texas, edited by T. R. Hester, S. L. Black, D. G. Steele, B. W. Olive, A. A. Fox, K. J. Reinhard, and L. C. Bement, pp. 39-62. Research Series No. 33. Arkansas Archeological Survey, Fayetteville.

1989b Central Texas Plateau Prairie. In From the Gulf Coast to the Rio Grande: Human Adaptation in Central South, and Lower Pecos Texas, edited by T. R. Hester, S. L. Black, D. G. Steele, B. W. Olive, A. A. Fox, K. J. Reinhard, and L. C. Bement, pp. 39-62. Research Series No. 33. Arkansas Archeological Survey, Fayetteville.

Blair, W. F.

1950 The Biotic Provinces of Texas. The Texas Journal of Science 2(1):93-117.

Bomar, G. W.

1983 Texas Weather. University of Texas Press, Austin.

Brown, K. M., D. R. Potter, G. D. Hall, and S. L. Black

1982 Excavations at 4lLK67, A Prehistoric Site in the Choke Canyon Reservoir, South Texas. Choke Canyon Series, Vol. 7. Center for Archaeological Research, The University of Texas at San Antonio.

Brune, G.

1981 Springs of Texas. Branch-Smith, Fort Worth.

Collins, M. B.

1995 Forty Years of Archeology in Central Texas. Bulletin of the Texas Archeological Society 66:361-400.

Doughty, R. W.

1983 Wildlife and Man in Texas: Environmental Change and Conservation. Texas A\&M University Press, College Station.

Figueroa, A. L., R. D. Greaves, and S. A. Tomka

2005 Intensive Pedestrian Survey of a 160-acre Tract in Webb County, Texas. Prepared for MACTEC Engineering \& Consulting, Inc. Manuscript on file, Center for Archaeological Research, The University of Texas at San Antonio.

Groat, G. G.

1976 Geologic Atlas of Texas: Laredo Sheet. Bureau of Economic Geology. The University of Texas at Austin.

Gustavson, T. C., and M. B. Collins

1998 Geoarcheological Investigation of Rio Grande Terrace and Flood Plain Alluvium, from Amistad Dam to the Gulf of Mexico. The University of Texas at Austin and the Texas Department of Transportation, Austin. 
Hall, G. D., S. L. Black, and C. Graves

1982 Archaeological Investigations at the Choke Canyon Reservoir, South Texas: The Phase I Findings. Choke Canyon Series, Vol. 5. Center for Archaeological Research, The University of Texas at San Antonio.

Hall, G. D., T. R. Hester, and S. L. Black (editors)

1986 The Prehistoric Sites at Choke Canyon Reservoir, Southern Texas: Results of the Phase II Archaeological Investigations. Choke Canyon Series, Vol. 10. Center for Archaeological Research, The University of Texas at San Antonio.

Hartle, D. D., and R. L. Stephenson

1951 Archaeological Excavations at the Falcon Reservoir, Starr County, Texas. In River Basin Surveys prepared for the Smithsonian Institution, Washington D.C.

Hester T. R.

1989 Historic Native American Populations. In From the Gulf to the Rio Grande: Human Adaptation in Central Texas, South, and Lower Pecos Texas, edited by T. R. Hester, S. L. Black, D. G. Steele, B. W. Olive, A. A. Fox, K. J. Reinhard, and L. C. Bement, pp. 77-84. Research Series No. 33. Arkansas Archeological Survey, Fayetteville.

1995 The Prehistory of South Texas. Bulletin of the Texas Archeological Society 66:427-459.

2004 The Prehistory of South Texas. In The Prehistory of Texas, edited by T. K. Perttula, pp. 127-151. Texas A\&M University Press, College Station.

Inglis, J. M.

1964 A History of Vegetation on the Rio Grande Plain. Bulletin No. 45. Texas Parks and Wildlife, Austin.

Mahoney, R. B., R. P. Mauldin, and S. A. Tomka

2002 Archeological Data Recovery Excavations along Becerra Creek (41WB556) Webb County, Texas. Archaeological Survey Report, No. 251. Center for Archaeological Research, The University of Texas at San Antonio. Archeological Studies Program, Report No. 44. Environmental Affairs Division, Texas Department of Transportation, Austin.

McGraw, A. J., and J. Thompson

1998 Campfires and Coal Dust in the Rio Grande: The Archeology and History of the Laredo-Colombia Solidarity International Bridge Site, Nuevo Leon, Mexico and Webb County, Texas. Archeological Studies Program, Report No. 8. Environmental Affairs Division, Texas Department of Transportation, Austin.

Miller, K. A., O. S. Carpenter, L. C. Nordt, and C. W. Ringstaff

2000 Archaeological Investigations along the Camino Colombia Toll Road, Webb County, Texas. SWCA Cultural Resource Report, No. 97-120. SWCA, Inc., Environmental Consultants, Austin.

Norwine, $\mathrm{J}$.

1995 The Regional Climate of South Texas: Patterns and Trends. In The Changing Climate of Texas: Predictability and Implications for the Future, edited by J. Norwine, J. Giardino, G. North, and J. Valdes, pp. 138-155. Texas A\&M University Press, College Station.

Perry, R. E.

2004 Report of Preliminary Cultural Resources Assessment of a Proposed Detention Facility, Webb County, Texas. MACTEC Engineering \& Consulting, Inc., Birmingham, Alabama. Prepared for The GEO Group, Inc., Boca Raton, Florida. Manuscript on file, Center for Archaeological Research, The University of Texas at San Antonio. 
Quigg, J. M., and C. Cordova

2000 Data Recovery at 41ZP364: An Upland Campsite at Falcon Reservoir, Zapata County, Texas. Technical Report No. 22317. TRC Mariah Associates Inc., Austin.

Quigg, M. J., C. Lintz, G. Smith, and S. Wilcox

2000 The Lino Site: A Stratified Late Archaic Campsite in a Terrace of the San Idelfonzo Creek, Webb County, Southern Texas. Archeological Studies Program, Report No. 20. Texas Department of Transportation Environmental Affairs Division, Austin. TRC Mariah Associates, Inc., Austin.

Quigg, J. M., S. Pritchard, and G. Smith

2002 The Boiler Site (41WB557): Utilization of an Upland Setting Over the Last 4200 Years, Webb County, Texas. Archeological Studies Program, Report No. 45. Environmental Affairs Division, Texas Department of Transportation, Austin. TRC Mariah Associates, Inc., Austin.

Sanders, R. R., and W. J. Gabriel

1985 Soil Survey of Webb County, Texas. U.S. Department of Agriculture, Soil Conservation Service in Cooperation with Texas Agricultural Experimental Station. Publishing Company, Houston.

Sellards, E. H.

1940 Pleistocene Artifacts and Associated Fossils from Bee County, Texas. Bulletin of the Geological Society of America $51: 1627-57$.

\section{Soil Survey Staff}

1981 Land Resource Regions and Major Land Resource Areas of the United States. In United States Department of Agriculture Soil Conservation Service Handbook 296:57-58.

1993 Soil Survey Manual. U.S. Department of Agriculture Handbook No. 18. U.S. Department of Agriculture. U.S. Government Printing Office, Washington, D.C.

Taylor, A. J., and C. L. Highley

1995 Archaeological Investigations at the Loma Sandia Site (41LK28): A Prehistoric Cemetery and Campsite in Live Oak County, Texas. 2 volumes. Studies in Archaeology No. 20. Texas Archeological Research Laboratory, The University of Texas at Austin.

Turpin, S. A.

1995 The Lower Pecos Region of Texas and Northern Mexico. Bulletin of the Texas Archeological Society 66:541560.

Vierra, B. J.

1998 41MV120: A Stratified Late Archaic Site in Maverick County, Texas. Archaeological Survey Report, No. 251, Center for Archaeological Research Center, The University of Texas at San Antonio, and Archeological Studies Program, Report No. 7, Texas Department of Transportation Environmental Affairs Division, Austin. 
Appendix A

Prehistoric Artifacts Recovered during MACTEC Previous Investigation 


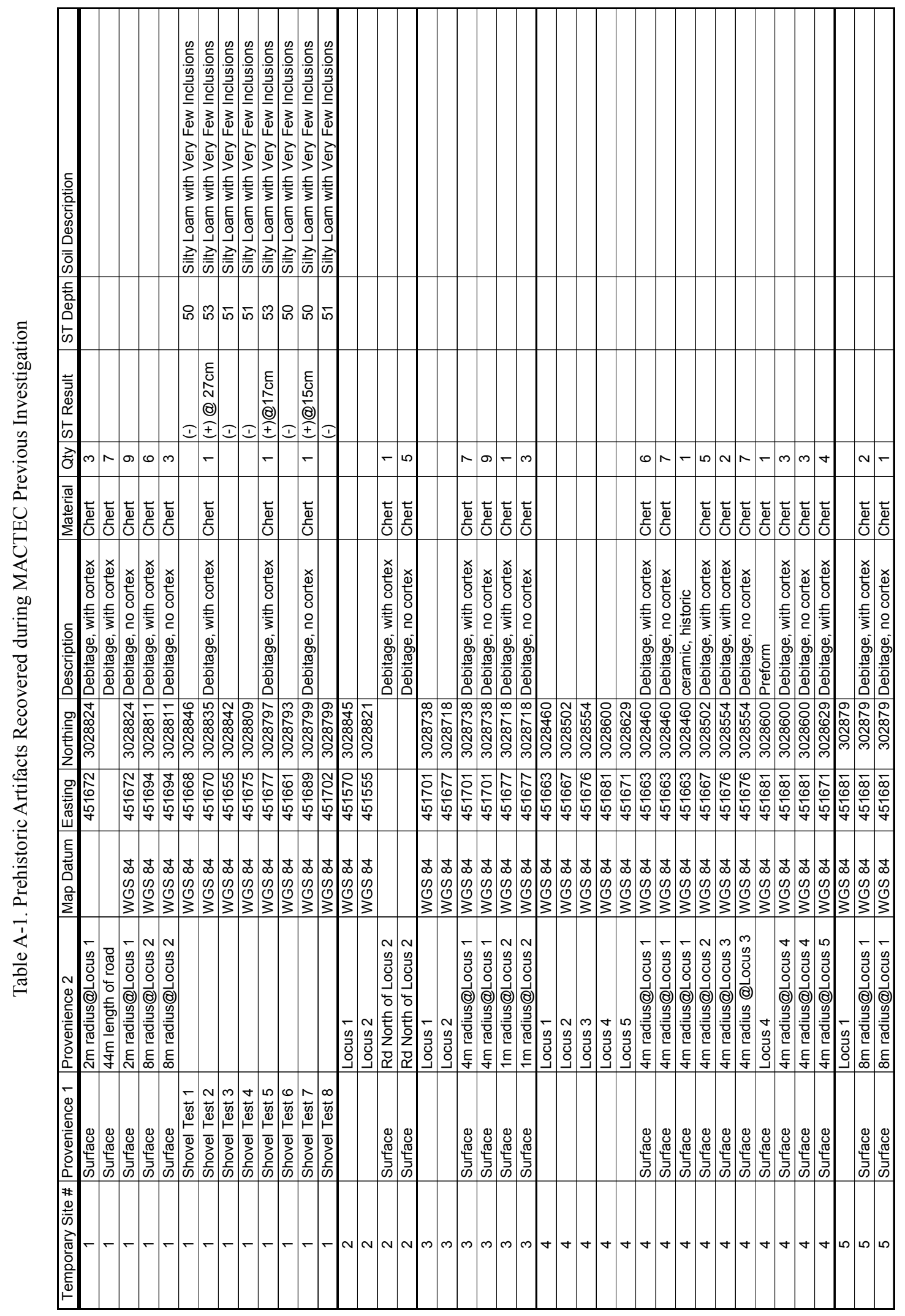




\section{Appendix B}

Historic Artifacts Recovered during MACTEC Previous Investigation 


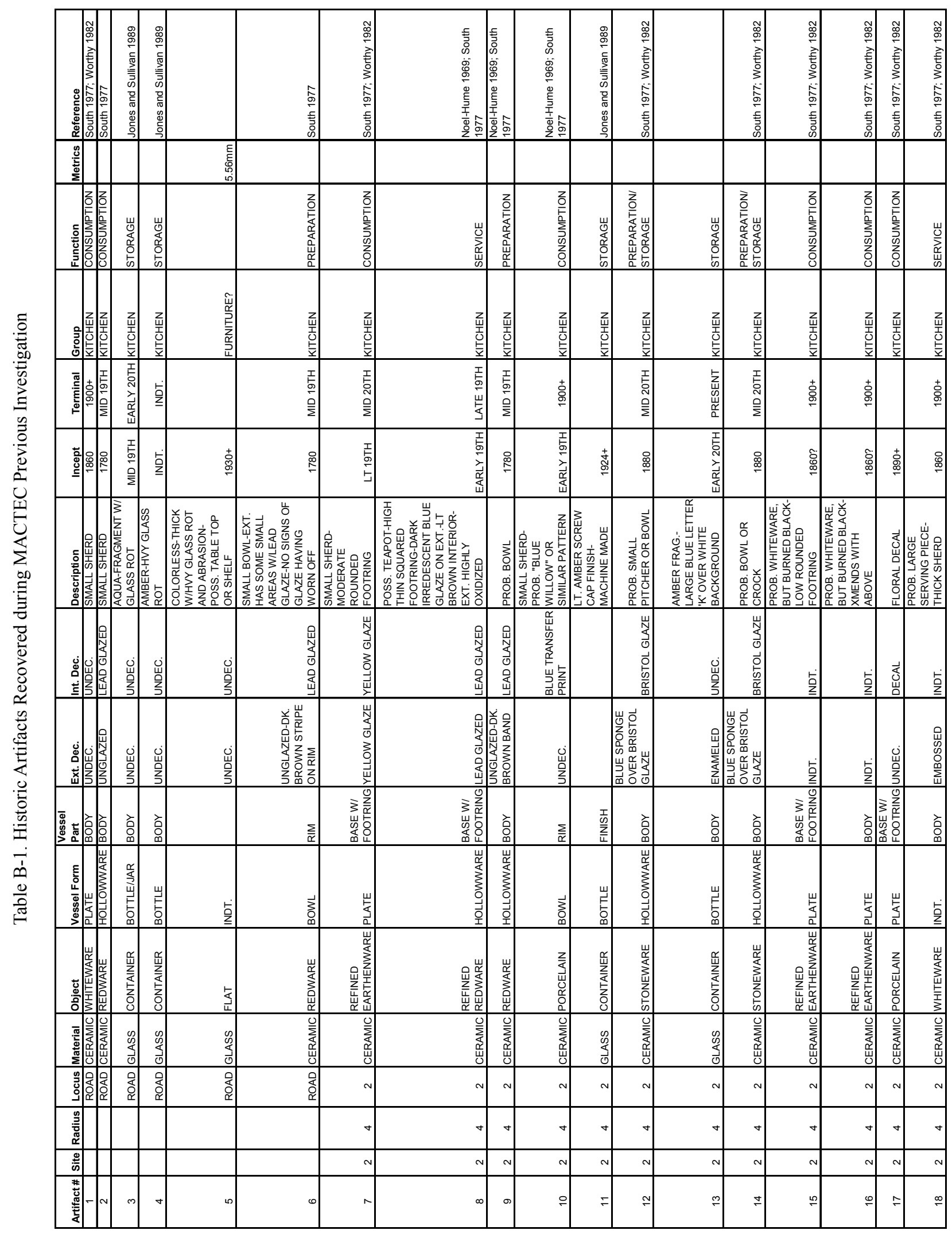




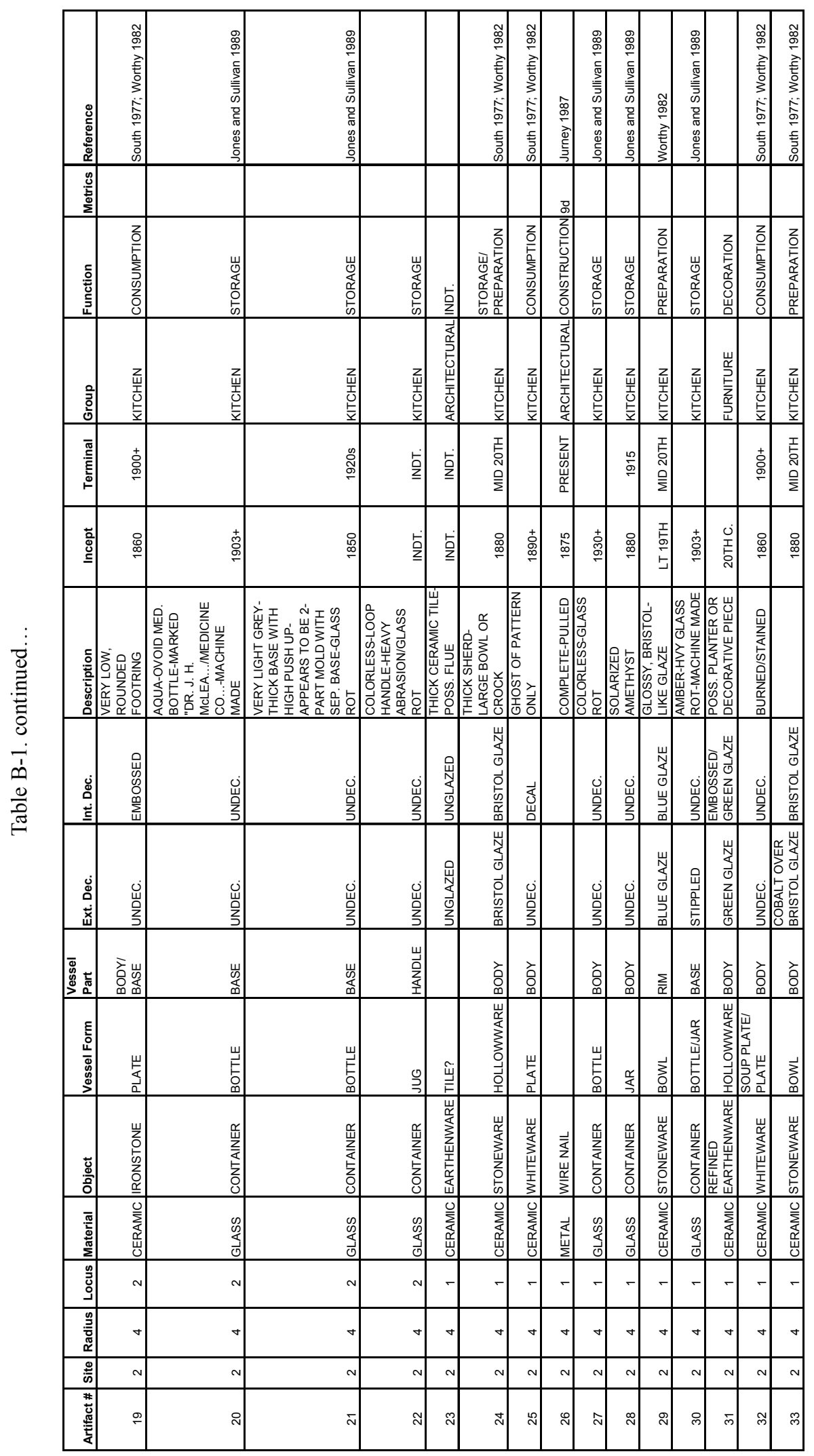




\section{References Cited}

Jones, O., and C. Sullivan

1989 The Parks Canada Glass Glossary, Revised Edition. Studies in Archaeology, Architecture and History, National Historic Parks and Sites, Canadian Park Service, Environment Canada, Ottawa.

Jurney, D. H.

1987 Cut and Wire Nails: Function and Temporal Interpretations. In Historic Buildings, Material Culture, and People of the Prairie Margin, edited by D. H. Jurney and R. W. Moir, pp. 83-96. Richland Creek Technical Series, Vol. V. Archaeology Research Program, Institute for the Study of Earth and Man, Southern Methodist University, Dallas, Texas.

Noel Hume, I.

1969 A Guide to Artifacts of Colonial America. University of Pennsylvania Press, Philadelphia.

South, S.

1977 Method and Theory in Historical Archaeology. Academic Press, New York.

Worthy, L. H.

1982 Classification and Interpretation of Late-Nineteenth and Early-Twentieth Century Ceramics. In Archaeology of Urban America: The Search for Pattern and Process, edited by R. S. Dickens, Jr., pp. 329-360. Academic Press, New York. 


\section{Appendix C}

Profile Descriptions for Selected Backhoe Trenches 


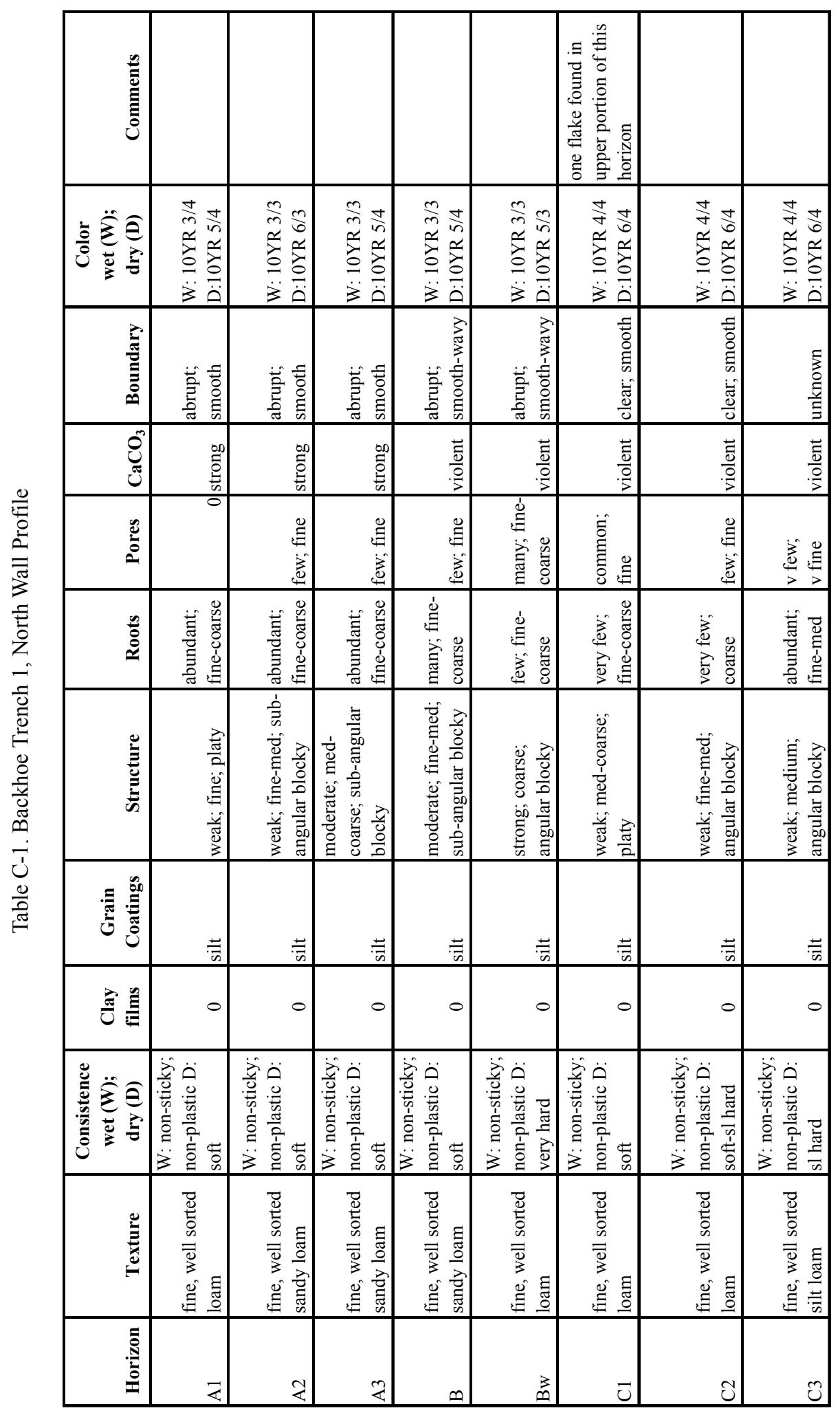




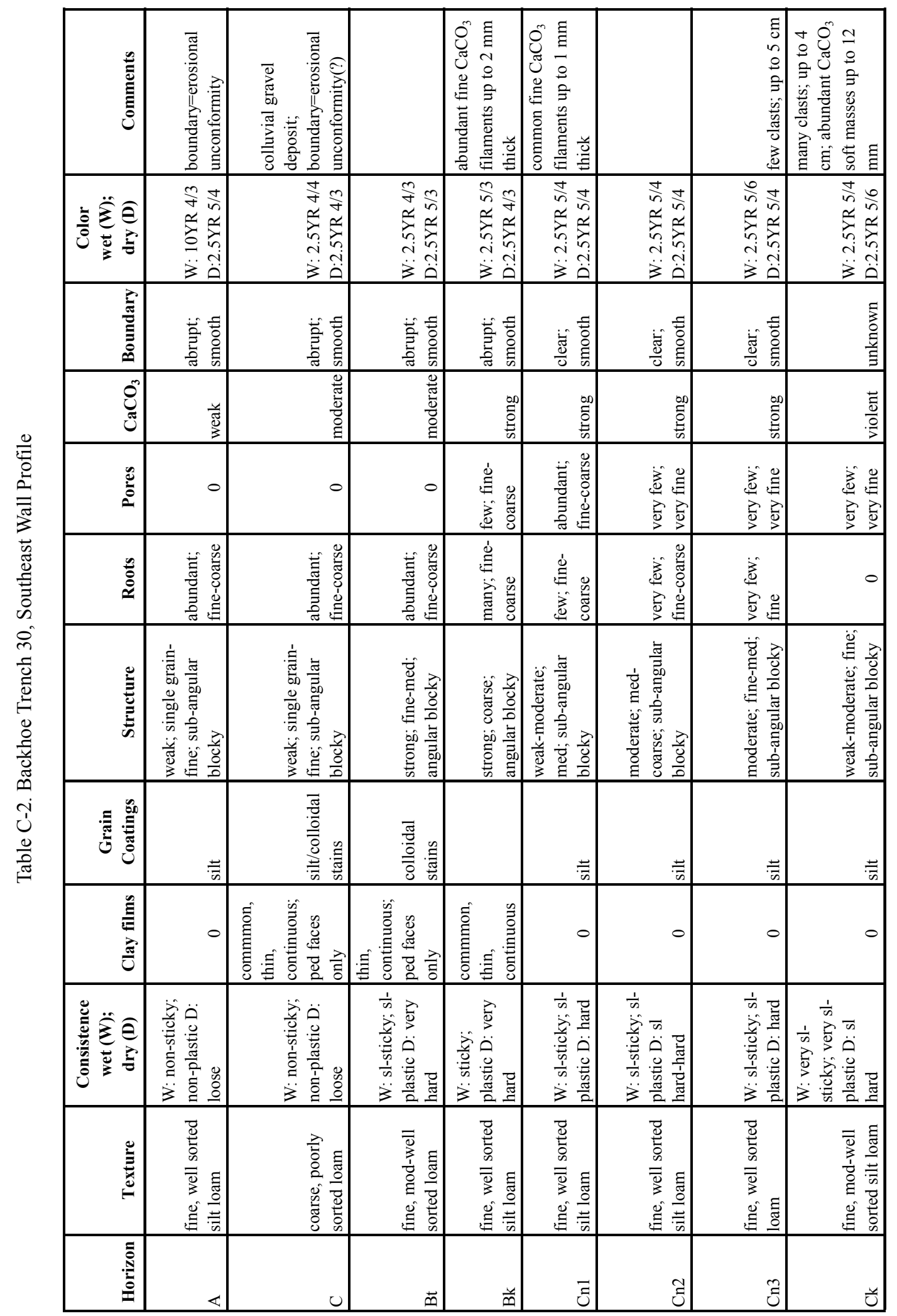




\begin{tabular}{|c|c|c|c|c|c|c|c|c|}
\hline 节 & & & 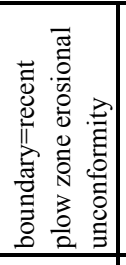 & 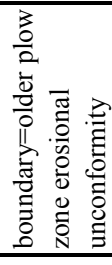 & & 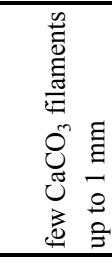 & 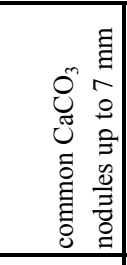 & 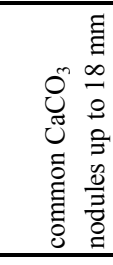 \\
\hline 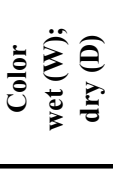 & 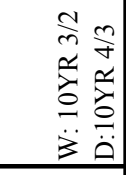 & 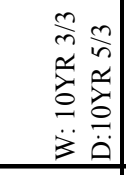 & 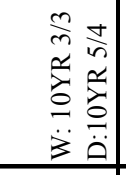 & 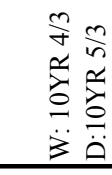 & 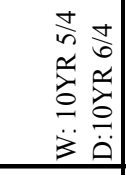 & 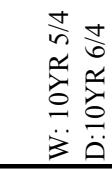 & 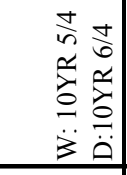 & 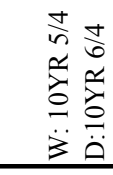 \\
\hline 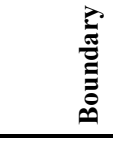 & 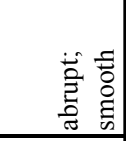 & 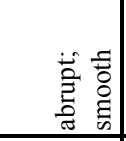 & 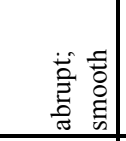 & 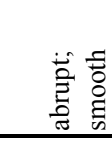 & 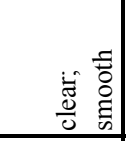 & 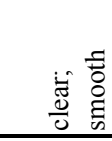 & 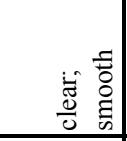 & 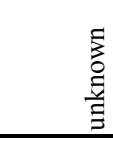 \\
\hline$\overbrace{\tilde{\pi}}^{\infty}$ & $\begin{array}{l}\text { bo } \\
\overline{0} \\
\overline{0}\end{array}$ & 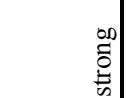 & 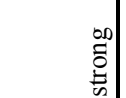 & 离 & $\begin{array}{l}\frac{\overrightarrow{0}}{\overrightarrow{0}} \\
\frac{0}{5}\end{array}$ & $\frac{\overrightarrow{0}}{\frac{0}{0}}$ & $\frac{\overrightarrow{0}}{\frac{\overrightarrow{0}}{5}}$ & $\frac{\overrightarrow{0}}{\frac{0}{0}}$ \\
\hline$\stackrel{\mathscr{o}}{\ddot{0}}$ & 0 & 0 & 0 & 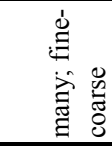 & $\begin{array}{c}0 \\
\stackrel{\Xi}{0} \\
\stackrel{0}{0} \\
\end{array}$ & 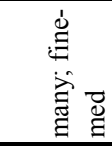 & 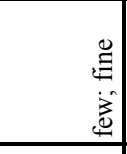 & 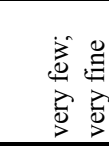 \\
\hline 䓂 & 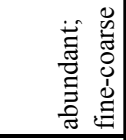 & 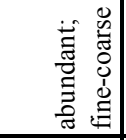 & 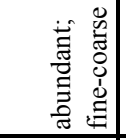 & 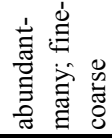 & 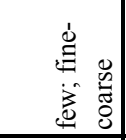 & 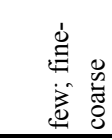 & 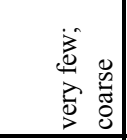 & 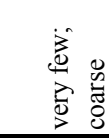 \\
\hline 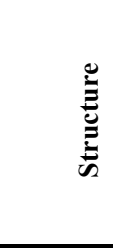 & 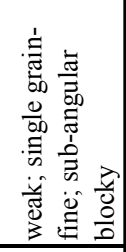 & 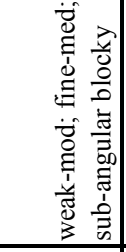 & 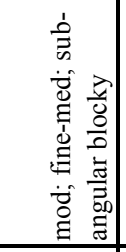 & 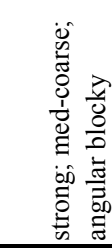 & 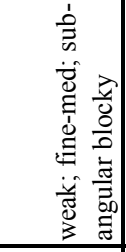 & 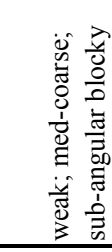 & 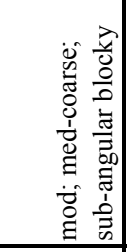 & 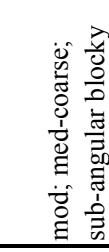 \\
\hline Uี & $\frac{ \pm}{5}$ & 苞 & $\vec{n}$ & 莺 & 莺 & 莺 & $=$ & 占 \\
\hline 窇产 & 0 & 0 & 0 & 0 & 0 & 0 & 0 & 0 \\
\hline 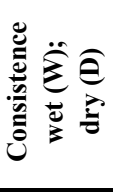 & 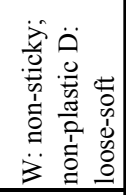 & 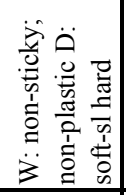 & 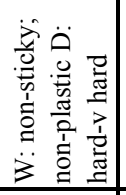 & 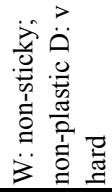 & 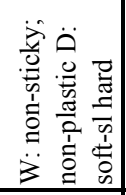 & 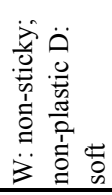 & 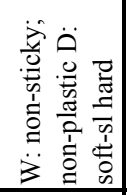 & 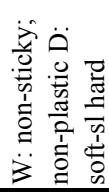 \\
\hline 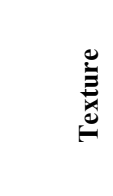 & 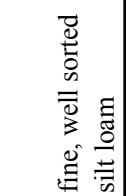 & 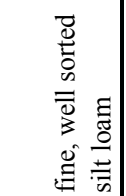 & 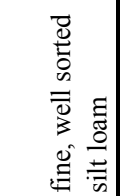 & 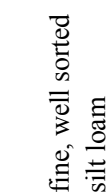 & 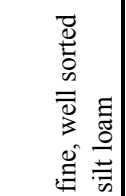 & 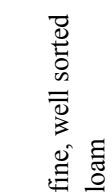 & 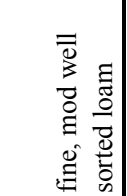 & 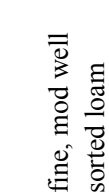 \\
\hline : & 妾 & 安 & 交 & 离 & $\bar{u}$ & $\frac{\pi}{0}$ & $\frac{\tilde{2}}{0}$ & 竎 \\
\hline
\end{tabular}




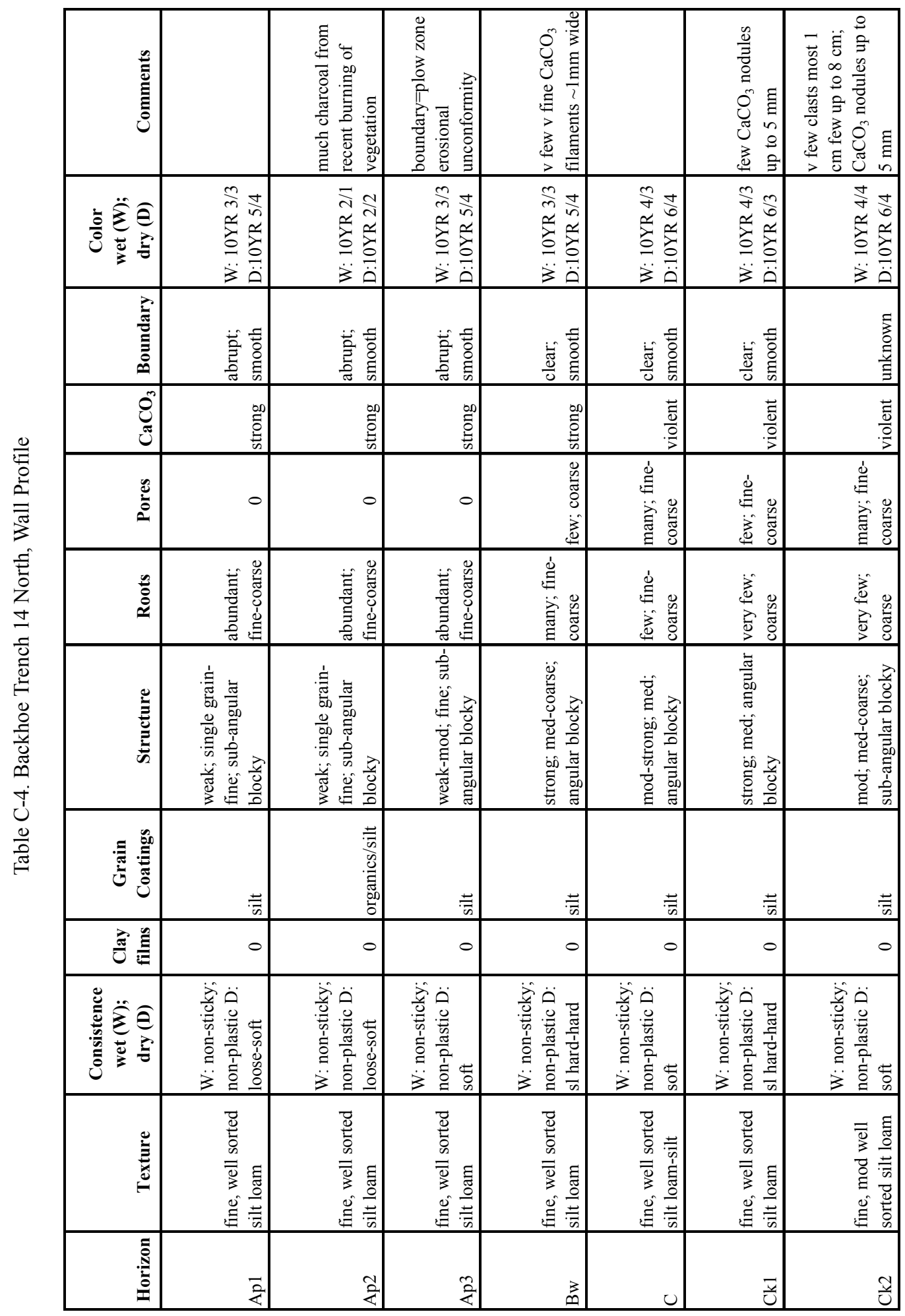




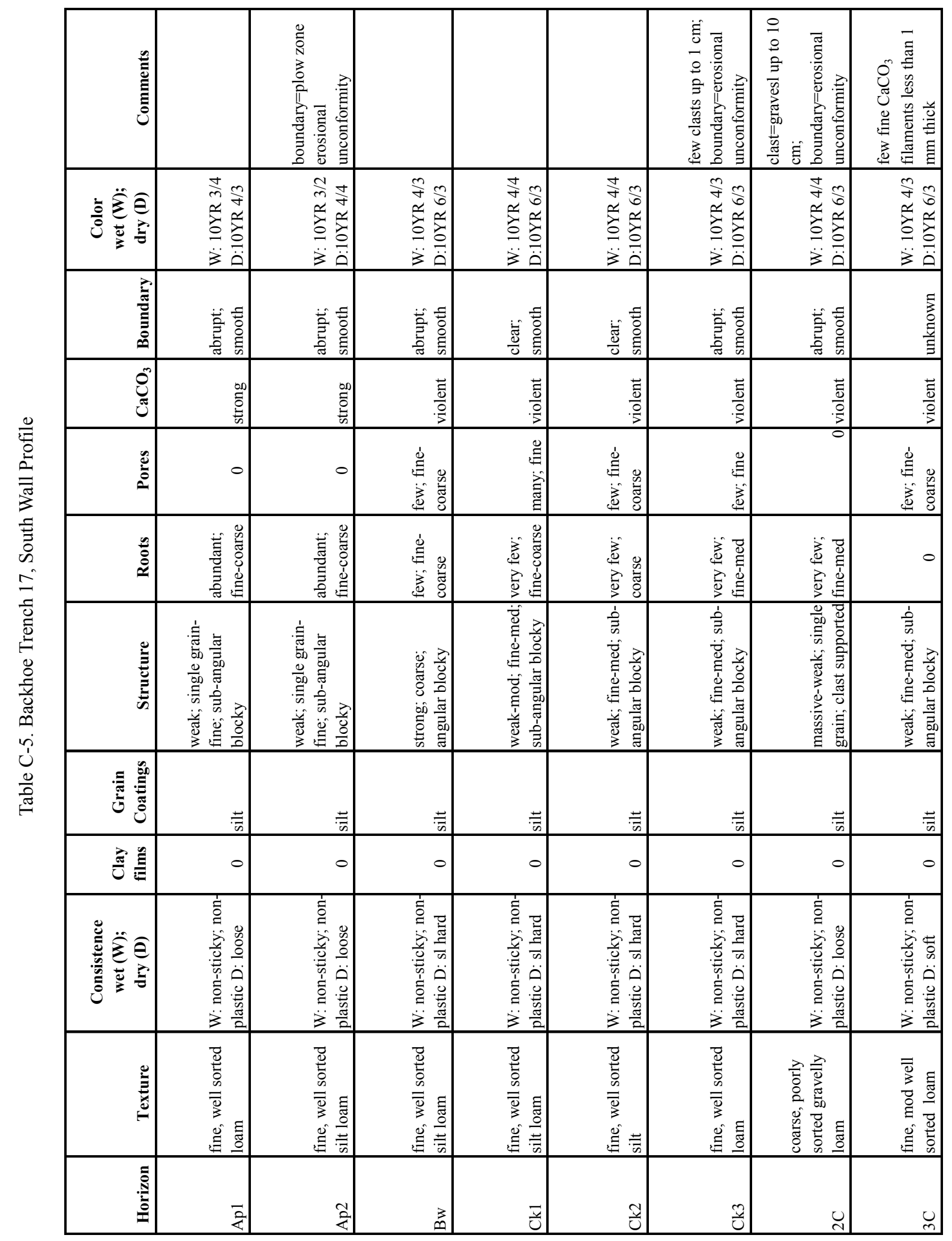




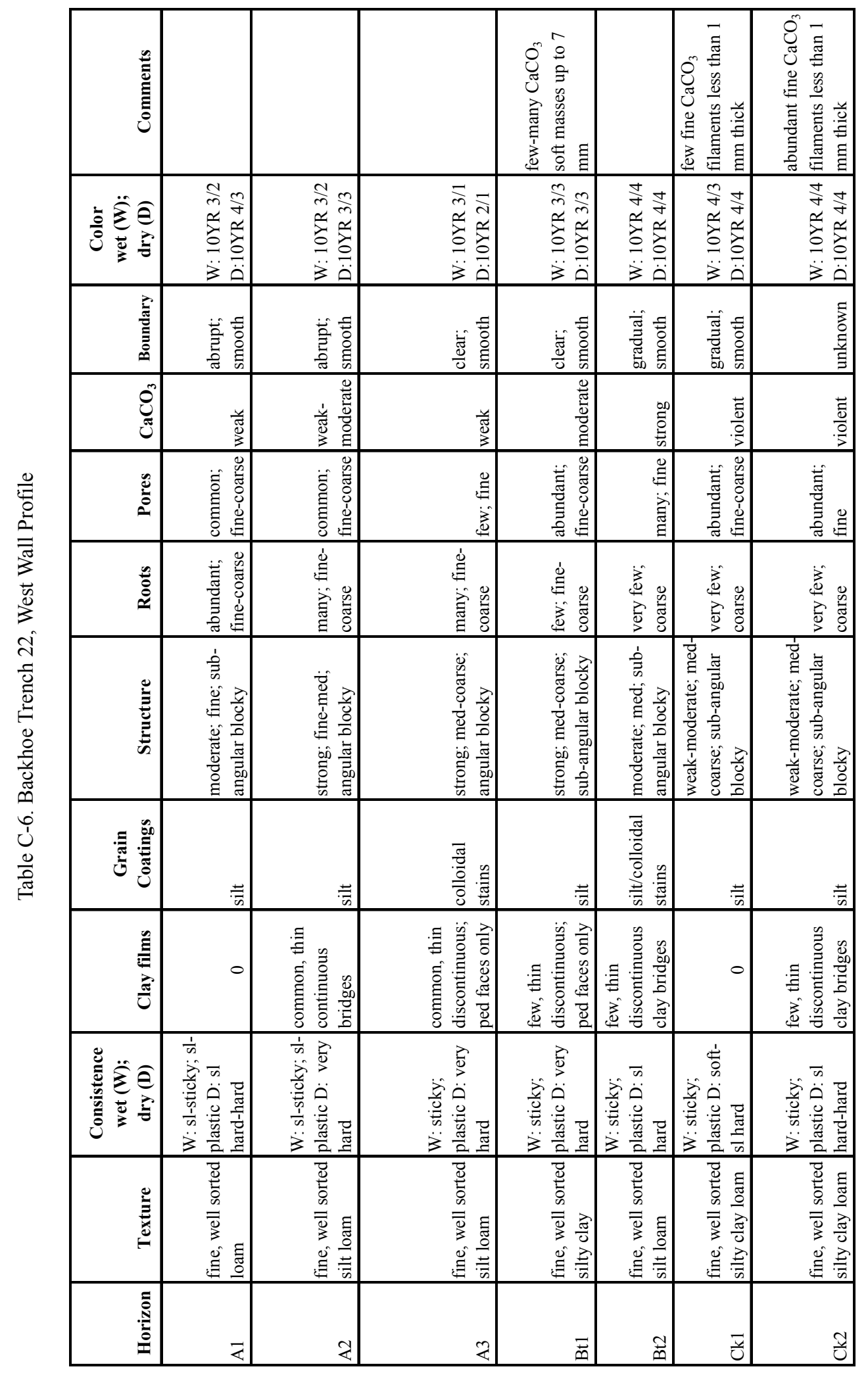




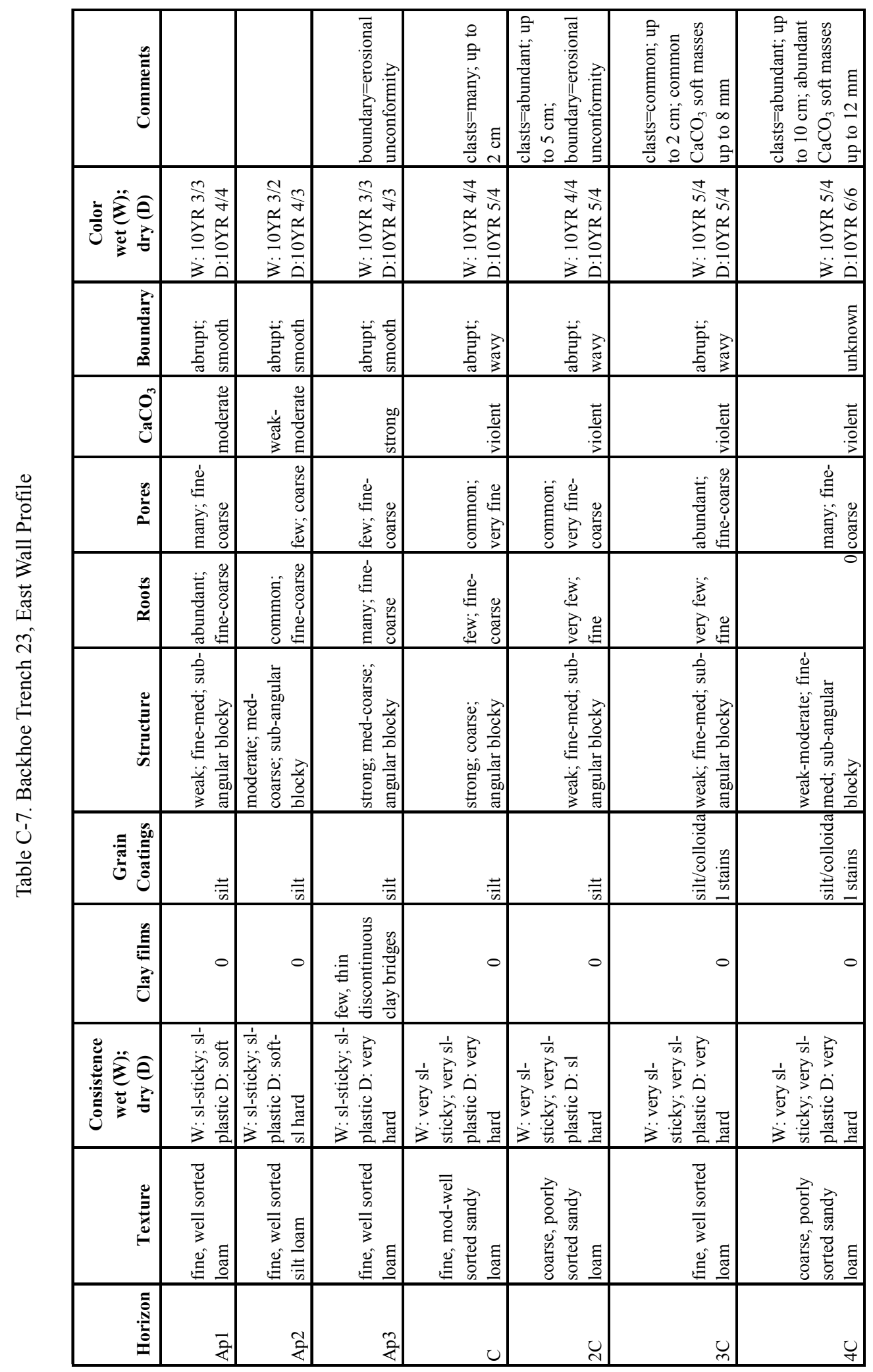




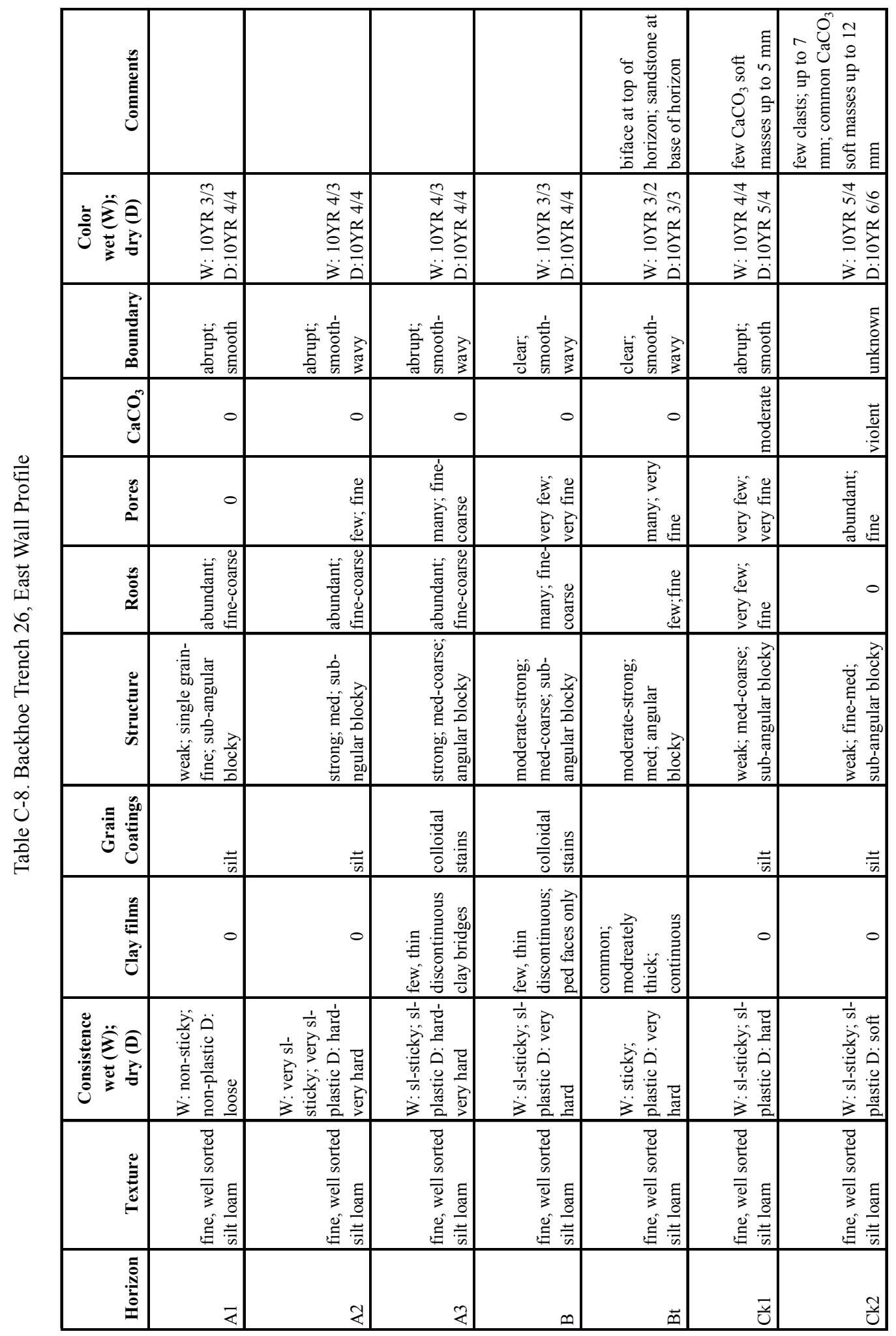




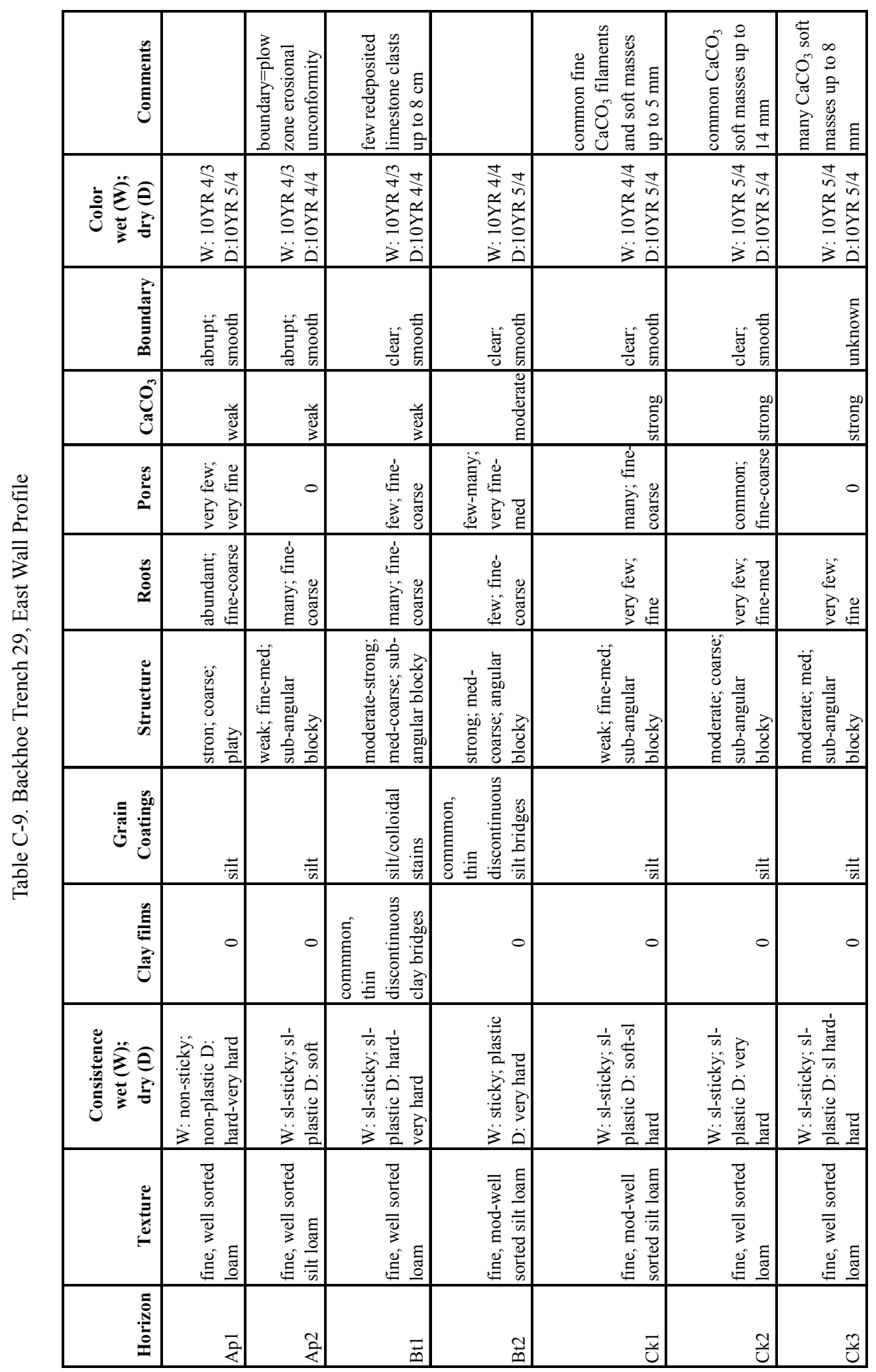




\begin{tabular}{|c|c|c|c|c|c|c|c|c|c|}
\hline 这 & & & & 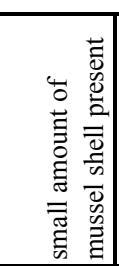 & 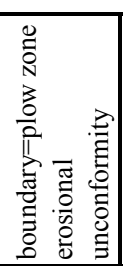 & & & $\begin{array}{l}n \\
n \\
0 \\
0 \\
0 \\
0 \\
0 \\
0 \\
0 \\
0 \\
3 \\
3 \\
0 \\
0\end{array}$ & 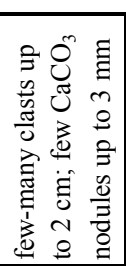 \\
\hline 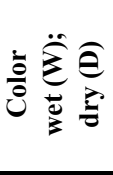 & 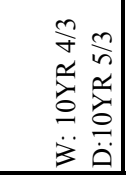 & 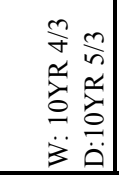 & 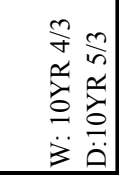 & 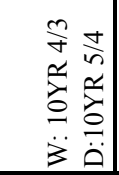 & $\begin{array}{cc}m & n \\
\hat{\sigma} & \tilde{n} \\
\tilde{z} & \tilde{z} \\
0 & \vdots \\
\ddot{3} & \dot{\theta}\end{array}$ & 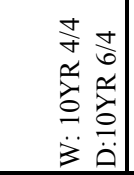 & 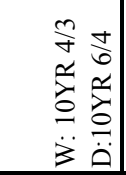 & 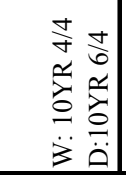 & 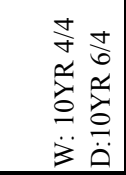 \\
\hline 萢 & 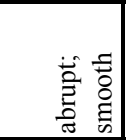 & 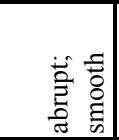 & 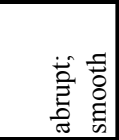 & 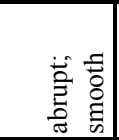 & 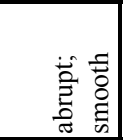 & 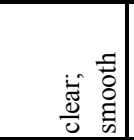 & 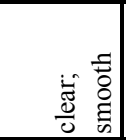 & 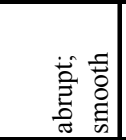 & $\begin{array}{l}\text { F } \\
\text { o } \\
\text { : }\end{array}$ \\
\hline$e_{0}^{n}$ & 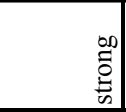 & 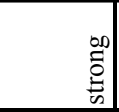 & 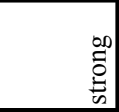 & $\begin{array}{l}\frac{\overrightarrow{0}}{0} \\
\frac{0}{0} \\
\frac{1}{7} \\
\end{array}$ & $\begin{array}{r}\overrightarrow{0} \\
\frac{\overrightarrow{0}}{0} \\
\frac{5}{7} \\
\end{array}$ & $\begin{array}{l}\overrightarrow{0} \\
\frac{0}{0} \\
\\
\end{array}$ & $\begin{array}{c}\frac{1}{0} \\
\frac{0}{0} \\
\end{array}$ & $\begin{array}{l}\overrightarrow{0} \\
\frac{\overrightarrow{0}}{0} \\
\end{array}$ & $\begin{array}{l}\frac{\overrightarrow{0}}{0} \\
\frac{0}{5} \\
\end{array}$ \\
\hline : & 0 & 0 & 0 & 0 & 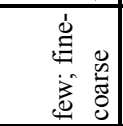 & 0 & 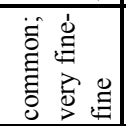 & 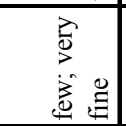 & 。 \\
\hline $\begin{array}{l}0 \\
\stackrel{0}{8}\end{array}$ & 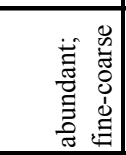 & 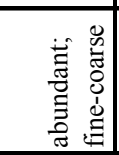 & 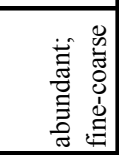 & 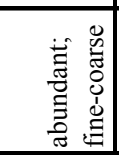 & 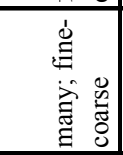 & 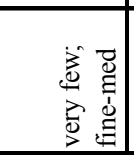 & 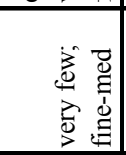 & 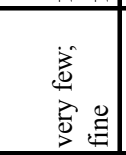 & 0 \\
\hline 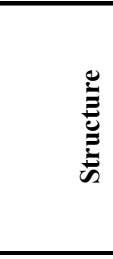 & 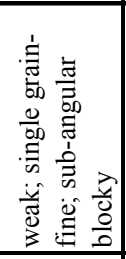 & 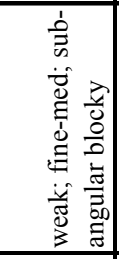 & 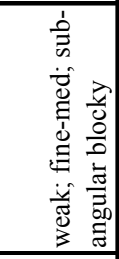 & 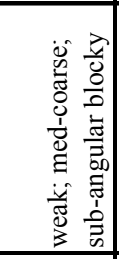 & 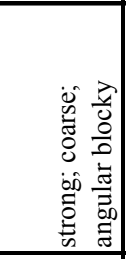 & 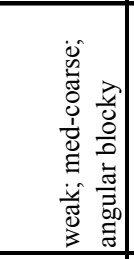 & 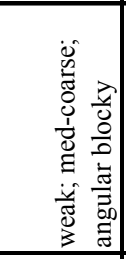 & 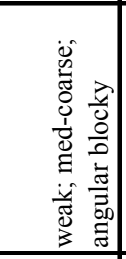 & 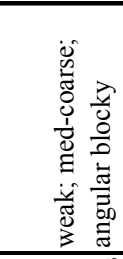 \\
\hline Uี & $\frac{n}{\bar{n}}$ & $\stackrel{\vec{c}}{\vec{n}}$ & $\frac{n}{\bar{v}}$ & $\frac{n}{n}$ & $\vec{t}$ & $\frac{n}{n}$ & $\frac{\vec{t}}{\vec{n}}$ & $\frac{\vec{n}}{\vec{n}}$ & 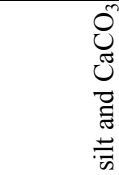 \\
\hline 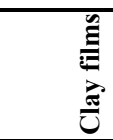 & 0 & 0 & 0 & 0 & 0 & 0 & 0 & 0 & 0 \\
\hline 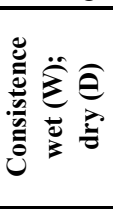 & 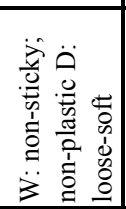 & 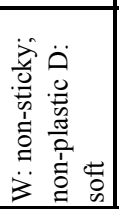 & 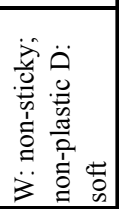 & 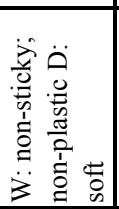 & 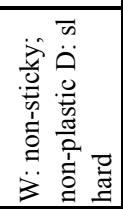 & 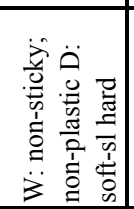 & 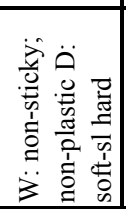 & 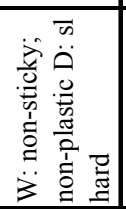 & 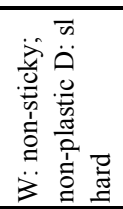 \\
\hline 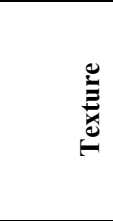 & 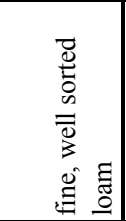 & 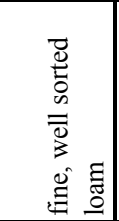 & 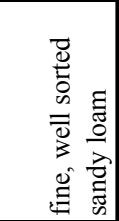 & 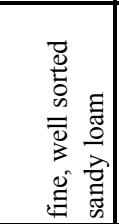 & 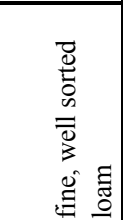 & 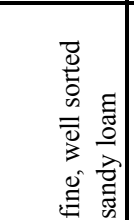 & 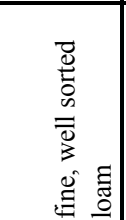 & 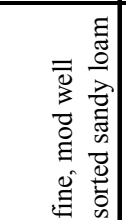 & 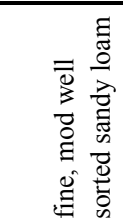 \\
\hline 产 & $\overrightarrow{<}$ & 定 & 妾 & 孛 & 菖 & $\vec{u}$ & ปै & $\frac{\tilde{\theta}}{U}$ & $\ddot{\breve{N}}$ \\
\hline
\end{tabular}




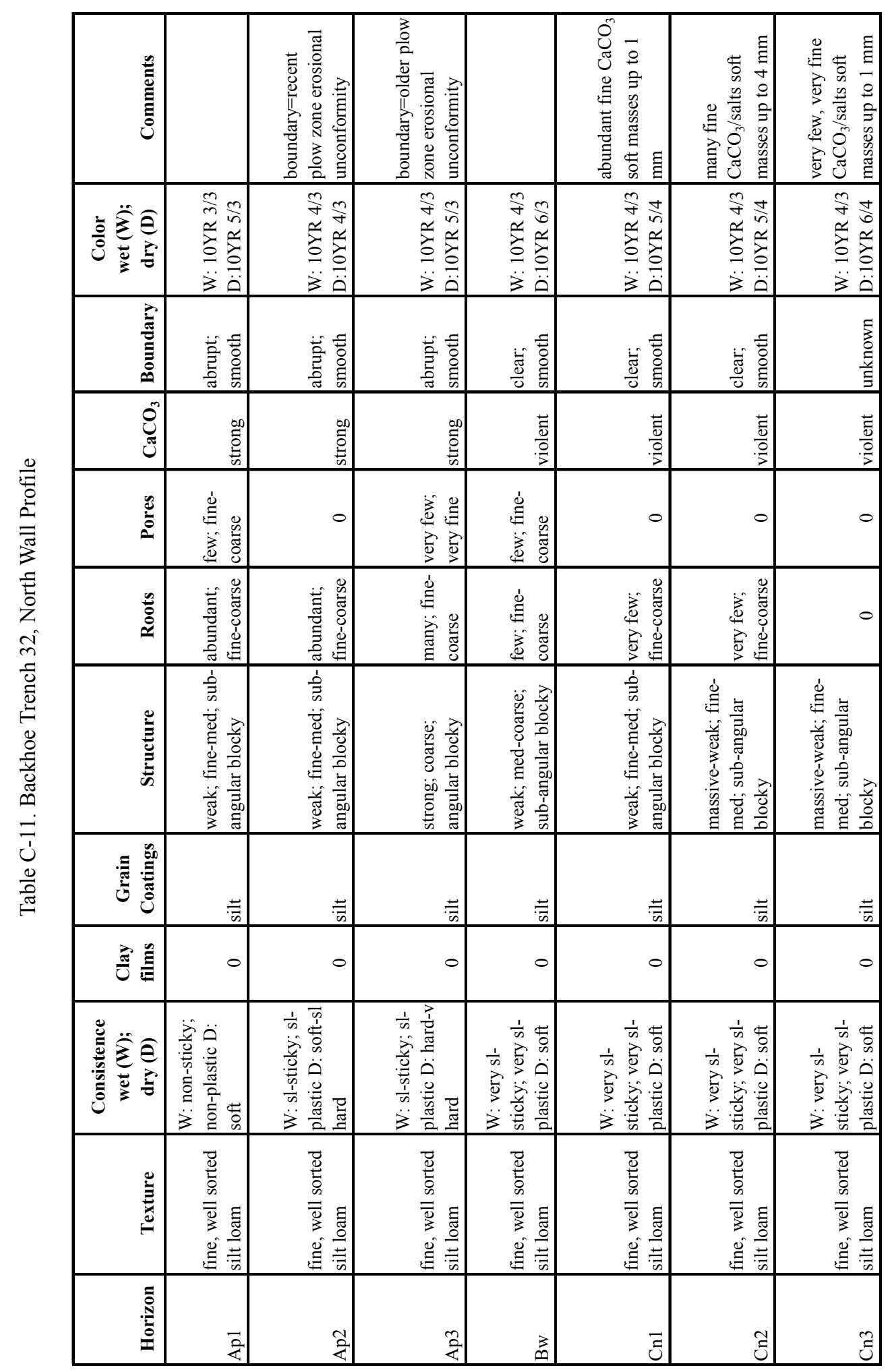


Appendix D

Magnetic Sediment Susceptibility Testing 


\title{
Appendix D: Magnetic Sediment Susceptibility Testing
}

\author{
Raymond P. Mauldin
}

Magnetic sediment susceptibility (MSS) has been used in a variety of contexts. In archaeological research, it has primarily been used on sediment as a method to help identify buried soils that may be associated with occupation (e.g., Takac and Gose 1998), as well as an aid in identifying heated sediment (Bellomo 1993; Dalan and Banerjee 1998). The magnetic susceptibility of a given sample can be thought of as a measure of how easily that sample can be magnetized (Dearing 1999; Gose and Nickels 2001).

While the measure of susceptibility is initially dependent on the mineralogy of a particular sample, that is the concentration and grain size of ferro- and ferrimagnetic minerals, a number of processes can result in an increase in MSS values in a sediment sample. These processes include an increase in the organic constitutes of the sediment and changes in the mineralogy of sediments in a given sample (see Collins et al. 1994; McClean and Kean 1993; Singer and Fine 1989). Sediments with higher organic content tend to have higher magnetic susceptibility values, probably as a result of the production of maghemite, an iron oxide, during organic decay (Reynolds and King 1995). Pedogenic processes, such as soil formation and weathering, can result in the concentration of organic material, as well as alterations in the mineralogy of a given zone. These processes can significantly increase susceptibility readings. Cultural processes, such as the concentration of ash, charcoal, and organic refuse, would also produce higher MSS readings. Modifications in magnetic susceptibility values also occur as a function of heating, a process documented by a number of researchers (Bellomo 1993; Crowther 2003; Dearing 1999; Farwig et al. 2004). On the current project, susceptibility samples were collected from three different contexts on two different sites (41WB635 and 41WB639) in an attempt to document buried surfaces that may have been associated with occupation.

\section{Procedures}

Fifty-eight samples, consisting of small quantities of sediment, were collected from profiles on 41WB639 from Test Units H and J. Samples were collected every $5 \mathrm{~cm}$ from the surface down to approximately $145 \mathrm{cmbs}$. On 41WB635, 10 samples were collected adjacent to Test Unit E, a unit that had produced high artifact densities. These samples were collected using a hand auger, with sampling at $10-\mathrm{cm}$ intervals. All samples were processed in the CAR laboratory. Sediment samples were air dried on a non-metal surface. After drying, sediment samples were ground to a uniform grain size using a ceramic mortar and pestle. This was done to standardize particle size and make the material both easier to handle and pack into sample containers. After each sample was prepared, the mortar and pestle were washed with tap water and wiped dry with a paper towel to avoid cross-sample contamination. The ground samples were then poured into sample containers consisting of plastic cubes with external dimensions of $2.54 \times 2.54 \mathrm{x}$ $1.94 \mathrm{~cm}$. The cubes have an average weight of 4.85 grams. The sediment filled cube was then weighed, and the weight of the sample calculated by subtracting the empty cube weight. This was done to correct for differences in mass. Assuming that sample volume and material is constant, larger samples should have higher susceptibility values simply as a function of greater mass.

The cube was then placed into a MS2B Dual Frequency Sensor that, in conjunction with a MS2 Magnetic Susceptibility Meter, provided a measure of the magnetic susceptibility of the sample (see Dearing 1999). For each cube, two readings were taken using the SI (standard international) scale, and the values were averaged. The resulting average value, referred to as volume specific susceptibility and noted with the symbol K. (Kappa), was recorded on a scale of $10^{-5}$, though there are no units associated with the value. That is, the value is dimensionless (Dearing 1999).

In order to correct for differences in sample weight, and provide units to the value $K_{\text {, }}$, the mass specific susceptibility value (X) was calculated using the formula

$$
X=\left(K_{0} / p\right)
$$

where $\mathrm{p}$ is the sample bulk density expressed in $\mathrm{kg} \mathrm{m}^{-3}$. The bulk density is determined by dividing the sample mass by volume. However, as all samples were measured in identical cubes, and all cubes were full, the sample volume is assumed to be constant. Only the mass of the sample varied. Mass specific susceptibility can be determined by

$$
\mathrm{X}=\mathrm{K}_{0} * \text { calibrated mass/sample mass }
$$


where sample mass is determined by subtracting the cube weight from the total sample weight (Dearing 1999). Calibrated mass is assumed to be 10 grams.

While the resulting values now have both a scale and associated units, the critical element for the current discussion is related to relative differences between sample values within a given profile or site, rather than absolute differences. That is, the principal interest is in rapid changes in the mass specific susceptibility values along a profile. This change may signal either a buried surface and/or cultural activity at that location.

The potential impacts of cultural activity on susceptibility values can be seen by considering a data set collected from an archaeological site (41BR473) located in Brown County, Texas. Two hundred and seventy-nine sediment susceptibility samples were collected from each level of over 50 shovel tests placed at this site by CAR staff. In all cases, the analytical procedures followed those outlined previously. Table D-1 presents summary data on all 279 cases, along with susceptibility scores for those settings that had firecracked rock (FCR) or chipped stone present. If cultural inputs result in higher susceptibility values, then it should be the case that significantly higher susceptibility values will be present in levels that have cultural material.

An examination of Table D-1 will demonstrate that this is indeed the case. Levels that have FCR present do have higher scores relative to those that lack FCR. Similarly, those levels that have chipped stone present have a higher average mass specific susceptibility score relative to those that lack chipped stone. As the distribution is approximately normal, a t-test was used to test the overall significance of these differences. In both the FCR and chipped stone comparisons, the test confirms that those levels with cultural material have significantly higher scores than those without cultural material (FCR t-statistic $=5.804, \mathrm{df}=277, \mathrm{p}<.001$; chipped stone $\mathrm{t}$-statistic $=2.674, \mathrm{df}=277, \mathrm{p}=.008$ ). This preliminary investigation, coupled with the previous work, clearly suggest that an analysis of the magnetic susceptibility of sediment can provide additional information on both the presence of buried surfaces, as well as the impact of cultural material on those surfaces.

\section{Results}

Table D-2 presents the results of the susceptibility analysis of the 10 samples from Test Unit E at 41WB635. An examination of the data, collected with a hand auger at 10$\mathrm{cm}$ levels from next to this 1-x-1-m unit, will demonstrate that MSS values range from between 168.6 and 185.4. Values are high at the surface (183.9) and then generally decline down to roughly 50-60 cmbs. Below about $60 \mathrm{cmbs}$, values again increase, with a peak occurring between 70 and $80 \mathrm{cmbs}$. This peak is consistent with either a buried surface and/or increased cultural activity.

Tables D-3 and D-4 list susceptibility results collected from two $50-\mathrm{x}-50-\mathrm{cm}$ units (TUs $\mathrm{H}$ and $\mathrm{J}$ ), excavated at 41WB639. Magnetic susceptibility values from Test Unit $\mathrm{H}$ range from a low of 138.3 to a high of 188.4 (125-130 cmbs), with most values falling between 140 and 160 (Table D-3). Values show a general decline from the surface down to $85-90 \mathrm{cmbs}$. Below $90 \mathrm{~cm}$, values begin to increase, with an initial peak occurring between 110 and $115 \mathrm{cmbs}$, and a secondary peak at $125-130 \mathrm{cmbs}$. Both of these peaks are consistent with the presence of a buried surface at these depths. Focusing on the results from Test Unit J (Table D4), the MSS values range from a low of 151.7 to a high of 174.3 (100 to $105 \mathrm{cmbs})$. There are three peaks reflected in the data, with a small peak occurring at $85-90 \mathrm{cmbs}$, and two larger peaks present at 100-105 cmbs and 115-120 $\mathrm{cmbs}$. Given the relative values, the two lower peaks have a good probability of reflecting buried surfaces.

Table D-1. Presence/Absence of Cultural Material and Mass Specific Sediment Susceptibility Scores for Shovel Tests at 41BR473

\begin{tabular}{|l|c|c|c|c|c|}
\hline & All Cases & $\begin{array}{c}\text { FCR } \\
\text { Present }\end{array}$ & FCR Absent & $\begin{array}{c}\text { Chipped Stone } \\
\text { Present }\end{array}$ & $\begin{array}{c}\text { Chipped Stone } \\
\text { Absent }\end{array}$ \\
\hline Number of Samples & 279 & 84 & 195 & 38 & 241 \\
\hline Mean Value & 48.3 & 56.9 & 44.6 & 55.2 & 47.2 \\
\hline Standard Deviation & 17.2 & 17.7 & 15.6 & 16.1 & 17.1 \\
\hline
\end{tabular}


Table D-2. Soil Susceptibility Values for Unit E, 41WB635

\begin{tabular}{|c|c|c|c|c|c|c|}
\hline Sample & Weight & Reading 1 & Reading 2 & Average & MSS Value & Depth (cm) \\
\hline 1 & 12.1 & 133.2 & 133.4 & 133.30 & 183.9 & 5 \\
\hline 2 & 12.4 & 138.5 & 138.7 & 138.60 & 183.6 & 15 \\
\hline 3 & 12.4 & 137.1 & 137.4 & 137.25 & 181.8 & 25 \\
\hline 4 & 12.1 & 122 & 122.5 & 122.25 & 168.6 & 35 \\
\hline 5 & 12.2 & 126.7 & 126.9 & 126.80 & 172.5 & 45 \\
\hline 6 & 12.1 & 122.8 & 122.7 & 122.75 & 169.3 & 55 \\
\hline 7 & 12.9 & 143.5 & 143.7 & 143.60 & 178.4 & 65 \\
\hline 8 & 12.9 & 149 & 149.2 & 149.10 & 185.2 & 75 \\
\hline 9 & 12.4 & 138.2 & 138.4 & 138.30 & 183.2 & 85 \\
\hline 10 & 12.3 & 138.2 & 138.1 & 138.15 & 185.4 & 95 \\
\hline
\end{tabular}

Table D-3. Soil Susceptibility Values for TU H, 41WB639

\begin{tabular}{|c|c|c|c|c|c|c|}
\hline Sample & Weight & Reading 1 & Reading 2 & Average & MSS Value & Depth (cm) \\
\hline 29 & 12.9 & 122.1 & 122.3 & 122.2 & 151.8 & 2.5 \\
\hline 28 & 13 & 123.3 & 123.3 & 123.3 & 151.3 & 7.5 \\
\hline 27 & 13.2 & 127.8 & 128.1 & 127.95 & 153.2 & 12.5 \\
\hline 26 & 12.4 & 115.5 & 115.5 & 115.5 & 153 & 17.5 \\
\hline 25 & 12.6 & 121.3 & 120.9 & 121.1 & 156.3 & 22.5 \\
\hline 24 & 12.9 & 122.4 & 122.4 & 122.4 & 152 & 27.5 \\
\hline 23 & 12.1 & 109.8 & 110.1 & 109.95 & 151.7 & 32.5 \\
\hline 22 & 12.2 & 110.1 & 110.5 & 110.3 & 150.1 & 37.5 \\
\hline 21 & 11.8 & 105.2 & 105.3 & 105.25 & 151.4 & 42.5 \\
\hline 20 & 12.1 & 105.7 & 105.8 & 105.75 & 145.9 & 47.5 \\
\hline 19 & 11.6 & 97 & 97.2 & 97.1 & 143.9 & 52.5 \\
\hline 18 & 12.4 & 108.4 & 108.6 & 108.5 & 143.7 & 57.5 \\
\hline 17 & 11.7 & 96.3 & 96.6 & 96.45 & 140.8 & 62.5 \\
\hline 16 & 12.4 & 111.9 & 111.8 & 111.85 & 148.1 & 67.5 \\
\hline 15 & 12.2 & 103.8 & 103.2 & 103.5 & 140.8 & 72.5 \\
\hline 14 & 12.7 & 112.4 & 112.5 & 112.45 & 143.2 & 77.5 \\
\hline 13 & 11.9 & 97.4 & 97.6 & 97.5 & 138.3 & 82.5 \\
\hline 12 & 11.5 & 93.3 & 93.2 & 93.25 & 140.2 & 87.5 \\
\hline 11 & 11.7 & 111.9 & 111.9 & 111.9 & 163.4 & 92.5 \\
\hline 10 & 10.7 & 99.9 & 100.1 & 100 & 170.9 & 97.5 \\
\hline 9 & 10.4 & 96.4 & 96.2 & 96.3 & 173.5 & 102.5 \\
\hline 8 & 8.3 & 59.5 & 59.6 & 59.55 & 172.6 & 107.5 \\
\hline 7 & 9.4 & 80.3 & 80.2 & 80.25 & 176.4 & 112.5 \\
\hline 6 & 8.4 & 58.5 & 58.5 & 58.5 & 164.8 & 117.5 \\
\hline 5 & 12 & 120.8 & 121 & 120.9 & 169.1 & 122.5 \\
\hline 4 & 12.8 & 149.8 & 149.7 & 149.75 & 188.4 & 127.5 \\
\hline 3 & 12.6 & 136.6 & 136.6 & 136.6 & 176.3 & 132.5 \\
\hline 2 & 13.4 & 144.6 & 144.6 & 144.6 & 169.1 & 137.5 \\
\hline 1 & 12.8 & 136.1 & 136.1 & 136.1 & 171.2 & 142.5 \\
\hline
\end{tabular}


Table D-4. Soil Susceptibility Values for TU J, 41WB639

\begin{tabular}{|c|c|c|c|c|c|c|}
\hline Sample & Weight & Reading 1 & Reading 2 & Average & MSS Value & Depth (cm) \\
\hline 29 & 12.7 & 120.1 & 120.2 & 120.15 & 153.1 & 2.5 \\
\hline 28 & 11.5 & 101.3 & 101.6 & 101.45 & 152.6 & 7.5 \\
\hline 27 & 12.1 & 111.5 & 111.8 & 111.65 & 154 & 12.5 \\
\hline 26 & 12.2 & 114.4 & 115.1 & 114.75 & 156.1 & 17.5 \\
\hline 25 & 12 & 110.8 & 111.1 & 110.95 & 155.2 & 22.5 \\
\hline 24 & 11.8 & 107 & 107.5 & 107.25 & 154.3 & 27.5 \\
\hline 23 & 11.8 & 108.2 & 108.6 & 108.4 & 156 & 32.5 \\
\hline 22 & 12.2 & 114.1 & 114.3 & 114.2 & 155.4 & 37.5 \\
\hline 21 & 12.1 & 109.9 & 110 & 109.95 & 151.7 & 42.5 \\
\hline 20 & 11.9 & 109.3 & 109.6 & 109.45 & 155.2 & 47.5 \\
\hline 19 & 12 & 113 & 113.5 & 113.25 & 158.4 & 52.5 \\
\hline 18 & 12.1 & 111.7 & 112 & 111.85 & 154.3 & 57.5 \\
\hline 17 & 12.3 & 117.7 & 118.3 & 118 & 158.4 & 62.5 \\
\hline 16 & 12.2 & 115.1 & 115.3 & 115.2 & 156.7 & 67.5 \\
\hline 15 & 12.1 & 113.2 & 113.9 & 113.55 & 156.6 & 72.5 \\
\hline 14 & 12.4 & 119.5 & 119.9 & 119.7 & 158.5 & 77.5 \\
\hline 13 & 12.2 & 118.2 & 118.5 & 118.35 & 161 & 82.5 \\
\hline 12 & 12.4 & 126.2 & 126.8 & 126.5 & 167.5 & 87.5 \\
\hline 11 & 12.1 & 120.8 & 120.9 & 120.85 & 166.7 & 92.5 \\
\hline 10 & 12.2 & 122.8 & 123.1 & 122.95 & 167.3 & 97.5 \\
\hline 9 & 12.8 & 138.4 & 138.7 & 138.55 & 174.3 & 102.5 \\
\hline 8 & 12.2 & 126.4 & 127 & 126.7 & 172.4 & 107.5 \\
\hline 7 & 12.5 & 128.8 & 129.2 & 129 & 168.6 & 112.5 \\
\hline 6 & 12.9 & 139.3 & 139.5 & 139.4 & 173.2 & 117.5 \\
\hline 5 & 12.8 & 135.6 & 135.8 & 135.7 & 170.7 & 122.5 \\
\hline 4 & 12.9 & 136.9 & 137.6 & 137.25 & 170.5 & 127.5 \\
\hline 3 & 12.8 & 136.4 & 136.8 & 136.6 & 171.8 & 132.5 \\
\hline 2 & 12.8 & 137.2 & 137.4 & 137.3 & 172.7 & 137.5 \\
\hline 1 & 11.7 & 119 & 119.1 & 119.05 & 173.8 & 142.5 \\
\hline
\end{tabular}

The MSS results from sites 41WB635 and 41WB639, then, suggest that both sites have evidence of buried surfaces that may be associated with archaeological occupation. On $41 \mathrm{WB} 635$, there is strong evidence for a buried surface at approximately $70-80 \mathrm{cmbs}$. At $41 \mathrm{WB} 639$, the pattern is slightly more complex, but considering both sets of data, it is probable that several buried surfaces are present between roughly $100 \mathrm{~cm}$ and $130 \mathrm{~cm}$ below the surface. 


\section{References Cited}

Bellomo, R. V.

1993 A Methodological Approach to Identifying Archaeological Evidence of Fire Resulting from Human Activities. Journal of Archaeological Science 20:523-553.

Collins, M. B., W. A. Gose, and S. Shaw

1994 Preliminary Geomorphological Findings at Dust and Nearby Caves. Journal of Alabama Archaeology 40:35-56.

Crowther, J.

2003 Potential Magnetic Susceptibility and Fractional Conversion Studies of Archaeological Soils and Sediments. Archaeometry 45:685-701.

Dalan, R. A., and S. K. Banerjee

1998 Solving Archaeological Problems Using Techniques of Soil Magnetism. Geoarchaeology 13:3-36.

Dearing, J.

1999 Environmental Magnetic Susceptibility. Chi Publishing, Kenilworth, England.

Farwig, V. J., S. H. Doerr, W. B. Blake, and R. A. Shakesby

2004 The Effects of Heating on Mineral Magnetic Enhancement of Soils: A Case Study Using Australian Soils. Geophysical Research Abstracts, Vol. 6, \#04912.

Gose, W. A., and D. L. Nickels

2001 Archaeomagnetic and Magnetic Susceptibility Analyses. In Test Excavations at the Culebra Creek Site, 41BX126, Bexar County, Texas. D. L. Nickels, C. B. Bousman, J. D. Leach, and D. A. Cargill, pp. 204-214. Archaeological Survey Report, No. 265, Center for Archaeological Research, The University of Texas at San Antonio. Archeology Studies Program, Report No. 3, Environmental Affairs Division, Texas Department of Transportation, Austin.

McClean, R. G., and W. F. Kean

1993 Contributions of Wood Ash Magnetism to Archeomagnetic Properties of Fire Pits and Hearths. Earth and Planetary Science Letters 119:387-394.

Reynolds, R. L., and J. W. King

1995 Magnetic Records of Climate Change. U.S. National Report to I.U.G.G., 1991-1994. American Geophysical Union. <http://www.agu.org/revgeophys/reyno100/reyno100.html> Accessed April 2001.

Singer, M. J., and P. Fine

1989 Pedogenic Factors Affecting Magnetic Susceptibility of Northern California Soils. Soil Science of America Journal 53:1119-1127.

Takac, P. R., and W. A. Gose

1998 Magnetic Susceptibility of Sediments. In Wilson-Leonard. An 11,000-year Archeological Record of HunterGatherers in Central Texas. Volume IV: Archeological Features and Technical Analyses, assembled and edited by M. B. Collins, pp:1329-1341. Studies in Archeology 31. Texas Archeological Research Laboratory, University of Texas at Austin. and Archeology Studies Program, Report No. 10, Environmental Affairs Division, Texas Department of Transportation, Austin. 
Appendix E

Letter from The GEO Group, Inc. with Description of the Nature of Impacts within the Facility Footprint 
August 18,2005

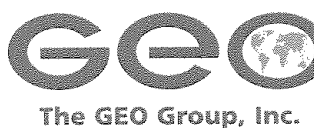

Corporate Headovarters

One Park Place, suite 700

621 Northwest 33 rd Street

Boca Raton, Florida 33487

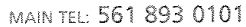

TOL FREE: 8663014436

Steve Tomka, Ph.D., Director

whw thegeogroupinc.com

Center for Archaeological Research

University of Texas at San Antonio

6900 North Loop 1604 West

San Antonio, Texas 78249-0658

Telephone: (210) 458-4379

Facsimile: (210) 458-4397

Steve.Tomka@utsa.edu

\section{Subject: $\quad$ THC Comments on the Proposed Webb County Detention Facility}

Dr. Tomka:

We understand that you received verbal comments from Debra Beene, Section 106 Reviewer for the Texas Historical Commission (THC), on August 16, 2005 regarding the Center for Archaeological Research (CAR), draft report on the proposed detention facility in Webb County Texas. We further understand that Ms. Beene has indicated that it is her opinion that the deep deposits on Archaeological Sites 41 WB637, 41WB638 and 41WB639 are potentially eligible for the National Register of Historic Places (NRHP) under Criterion D of the NRHP Eligibility Criteria.

We are in agreement that the deep deposits at Site 41WB639 are NRHP eligible and we have previously agreed that the deep deposits at this site will be avoided. Within the vicinity of Sites $41 \mathrm{WB} 637$ and $41 \mathrm{WB} 638$, the current project design includes only shallow impacts associated with general landscaping of the project area and consequently, the proposed project should not impact potentially NRHP eligible deposits below the plow zone.

Sincerely,

The GEO Group, Inc.

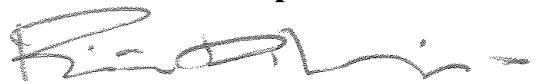

Dr. Philip D. Mosciski, DBA, AIA

Vice President, Design Development

cc: Robert Perry 